MARCOS ANTÔNIO GIMENES SANCHES

\title{
A INFLUÊNCIA DOS ESTILOS DE GESTÃO NAS ESTRATÉGIAS DE INOVAÇÃO EM PEQUENAS EMPRESAS: \\ UM ESTUDO MULTICASOS DE PEQUENAS EMPRESAS DO PÓLO TECNOLÓGICO DE SÃO CARLOS - SP
}

Dissertação de mestrado apresentada à Escola de Engenharia de São Carlos, da Universidade de São Paulo, como parte dos requisitos para obtenção do Título de Mestre em Engenharia de Produção.

ORIENTADOR: Prof. Dr. Edmundo Escrivão Filho

São Carlos, outubro de 2005 



\section{DEDICATÓRIA}

Aos meus pais, Patrício e Lourdes, exemplos de honestidade e perseverança. À minha esposa Lilian, pelo amor, incentivo e apoio necessário, em todos os momentos deste trabalho. 



\section{AGRADECIMENTOS}

Agradeço a todos que, de alguma forma, colaboraram para a realização desse trabalho.

Ao Prof. Dr. Edmundo Escrivão Filho, os mais profundos agradecimentos, tanto pela dedicação quanto pelo profissionalismo demonstrado, que tanto fizeram a diferença no resultado final do trabalho. Seu companheirismo e motivação foram essenciais na condução das diversas atividades realizadas.

Aos amigos Paulo Paiva e Alexandre Duarte, que me fizeram acreditar na possibilidade de chegar aonde cheguei.

Aos colegas do GEOPE: Ana Cláudia, Ana Laura, Antônio, Giseli, Raquel e, em especial, ao amigo Sérgio Perussi Filho, pelo apoio na obtenção dos dados.

Ao amigo, Sílvio Hiroshi Nakao, pela paciência e dedicação na leitura das versões preliminares, como também pelas críticas e sugestões que muito enriqueceram este trabalho.

Às empresas pesquisadas, que prontamente abriram suas portas, possibilitando o levantamento de todo o material necessário para a realização da pesquisa de campo.

Aos que não tiveram seus nomes relacionados; tenham a certeza de que serei eternamente grato pelo apoio. 



\section{RESUMO}

SANCHES, M. A. G. (2005). A influência dos estilos de gestão nas estratégias de inovação em pequenas empresas: um estudo multicasos de pequenas empresas do Pólo Tecnológico de São Carlos - SP. Dissertação (Mestrado) Escola de Engenharia de São Carlos, Universidade de São Paulo.

Esta pesquisa tem como objetivo geral avaliar os estilos de gestão encontrados em pequenas empresas, identificando quais de seus componentes possuem efeito na postura inovativa destas empresas. A argumentação é que as pequenas empresas, motivadas pela necessidade de sobrevivência num ambiente competitivo e dinâmico, necessitam ser inovadoras. São também objetivos desta pesquisa: a revisão da literatura sobre as pequenas empresas, a compreensão das particularidades de gestão delas, bem como a conceituação de inovação. Para alcançar o objetivo proposto foi realizada pesquisa bibliográfica e um estudo multicasos, de caráter exploratório, em três empresas da cidade de São Carlos, localizada no estado de São Paulo. A coleta de dados se deu por meio de entrevistas estruturadas, em que se aplicou um questionário pré-estabelecido e também foi utilizado um roteiro previamente definido. Além disso, os dados foram complementados com pesquisas em documentos das respectivas empresas, em revistas, livros, jornais e também no SEBRAE e na Prefeitura Municipal de São Carlos. A interpretação dos dados foi de caráter qualitativo. Ao final, a pesquisa demonstrou que os gestores têm dificuldades para a elaboração de estratégias para a inovação, principalmente por não se distanciarem dos problemas operacionais do dia-a-dia. As alterações nos produtos e processos, quando ocorrem, estão sempre direcionadas para a adequação de custos. O desenvolvimento de novos processos é confiado à habilidade dos funcionários, sem um processo sistemático para que isso ocorra. Há um receio na quebra dos padrões de mercado, agravado pela grande preocupação com o nível de qualidade exigido pelos clientes.

Palavras-chave: competitividade, estilos de gestão, inovação, pequenas empresas. 



\begin{abstract}
SANCHES, M.A.G. (2005). The influence of the management styles in the strategies of innovation in small companies: a multicases study in small companies in the Technological Pole of São Carlos- SP. Dissertation (Master Degree) - Engineering School of São Carlos, University of São Paulo.
\end{abstract}

This research has as general aim to evaluate the management styles found in small companies, identifying which one of its components get an effect in the innovative posture of these companies. The argumentation is that the small companies, motivated by the necessity of survival in a competitive and dynamic environment, need to be innovative. This study also has as objectives: the reviewing of literature about small companies, the comprehension of the particularities of management in small companies and the conceptualization of innovation. To reach the objective it was carried out a bibliographic study of multicases, of exploratory in three companies from São Carlos town, located in the State of São Paulo. The data were collected through structured interviews. It was applied a pre-prepared questionnaire and it was used a schedule previously defined. Besides this, the data were collected through research in documents of the respective companies, as well as in magazines, books, newspapers and also at SEBRAE and the Municipal Hall of São Carlos. The interpretation of the data was of qualitative nature. At the final, the research demonstrated that the managers have difficulties to the elaboration of strategies for innovation, especially because they can't get the distance of the daily operational problems. The changes in the products and processes, when they occur, are always directed to the adjustment of costs. The development of new processes is relied to the skills of the workers, without a systematic process to occur. There is a break of market standards, worsen by the great concern with the level of quality wanted by the clients.

Key-words: competitivity, management styles, innovation, small companies. 



\section{LISTA DE FIGURAS}

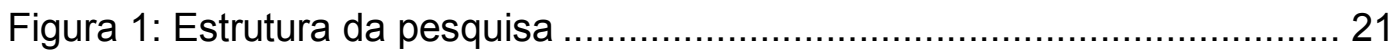

Figura 2: As cinco partes básicas da organização. ........................................ 32

Figura 3: Os estágios da tomada de decisão ............................................... 34

Figura 4: As cinco forças que impulsionam a organização. .............................. 35

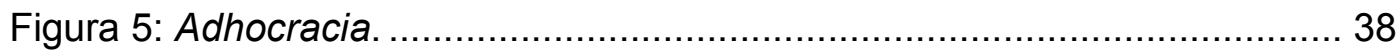

Figura 6: O processo gerencial dos empreendedores. ................................... 40

Figura 7: A Teoria do Ciclo Vital da Liderança. .............................................. 46

Figura 8: Supervisores concentrados: no empregado versus no serviço...... 47

Figura 9: Mestres punitivos versus mestres não punitivos. .......................... 48

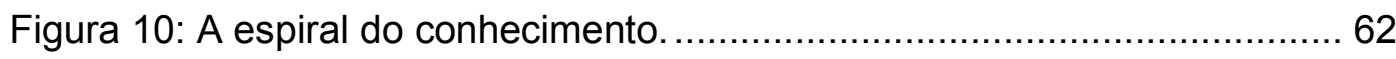

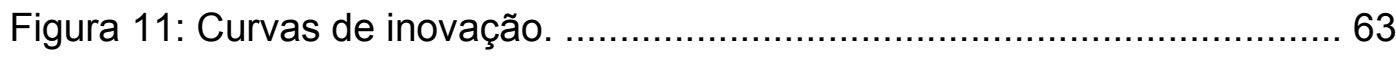

Figura 12: Retorno do investimento versus parcela de mercado. ................. 67

Figura 13: Curva "U" e estratégias competitivas ampliadas. ............................. 68

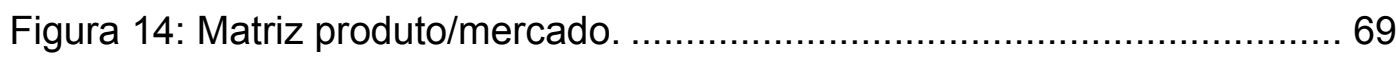

Figura 15: A Matriz BCG. .................................................................... 70

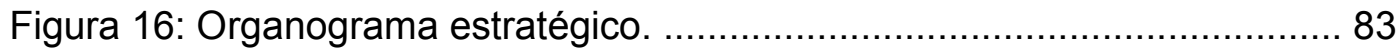

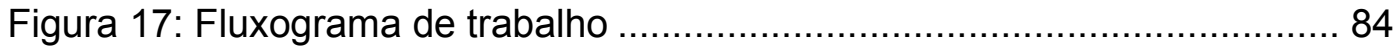

\section{LISTA DE TABELAS}

Tabela 1: Nascimentos e mortes das empresas no Brasil ............................... 27

Tabela 2: Inovações de pequenas empresas no século XX........................... 71

Tabela 3: Critérios de classificação das MPE ............................................... 78

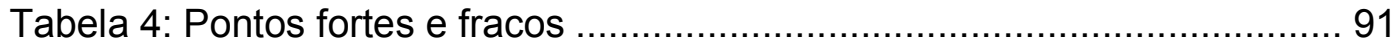

Tabela 5: Ameaças e oportunidades....................................................... 92 



\section{SUMÁRIO}

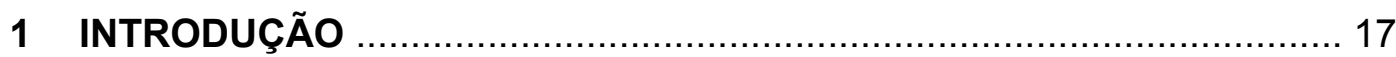

1.1 CARACTERIZAÇÃO DO TEMA DE PESQUISA ….............................18

1.2 FORMULAÇÃO DO PROBLEMA DE PESQUISA ...............................19

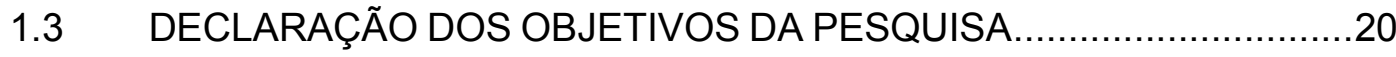

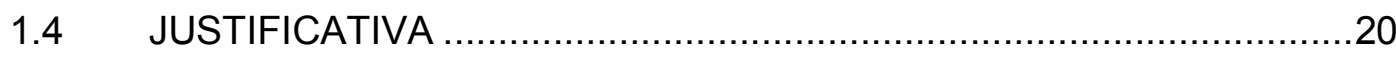

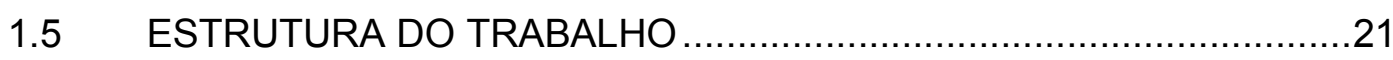

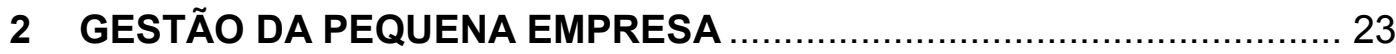

2.1 DIFICULDADES DA PEQUENA EMPRESA NO BRASIL ...................24

2.2 ORGANIZAÇÃO NAS PEQUENAS EMPRESAS...............................28

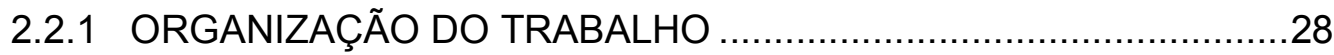

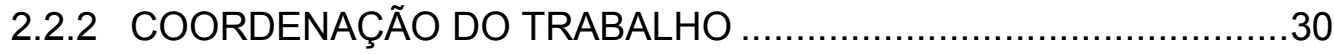

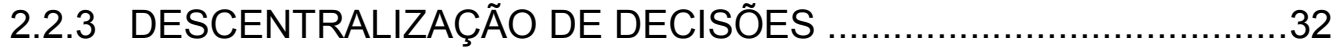

2.2.4 AS CINCO ESTRUTURAS DE MINTZBERG ...............................34

2.2.5 ASPECTOS DA GESTÃO NA PEQUENA EMPRESA ….................39

3 CARACTERÍSTICAS E ESTILOS DE GESTÃO ….............................. 42

3.1 A TEORIA DE TRAÇOS DE PERSONALIDADE ...............................43

3.2 TEORIAS SOBRE ESTILOS DE LIDERANÇA ................................44

3.2.1 A TEORIA DE HERSEY E BLANCHARD DO CICLO DE

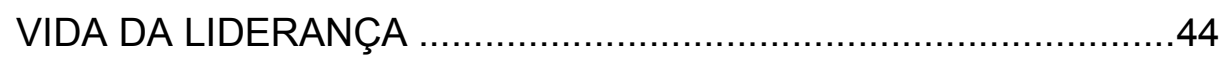

3.2.2 OS ESTUDOS DO INSTITUTE FOR SOCIAL RESEARCH.............46

3.2.3 ABORDAGEM SITUACIONAL DA LIDERANÇA ............................48

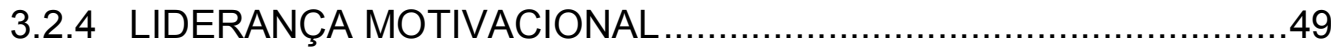

3.3 CARACTERÍSTICAS FUNCIONAIS E A INOVAÇÃO ……..................50

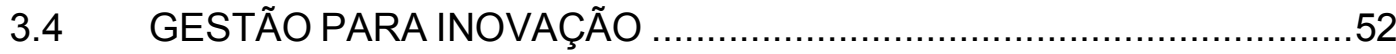

4 GESTÃO DA INOVAÇÃO EM PRODUTOS E PROCESSOS ………........ 56

4.1 APRENDIZAGEM E CRIAÇÃO DE CONHECIMENTO …....................58

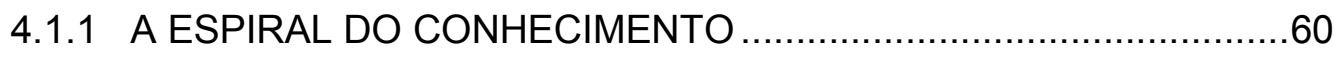

4.2 A NOVIDADE E A INOVAÇÃO

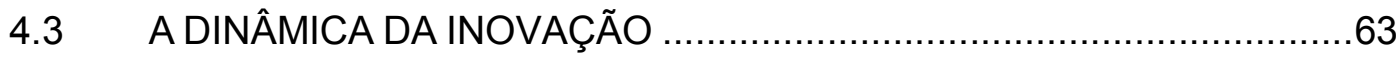


4.4 A ESTRUTURA DE DESENVOLVIMENTO DE PRODUTOS

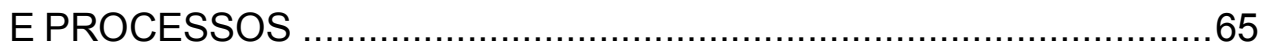

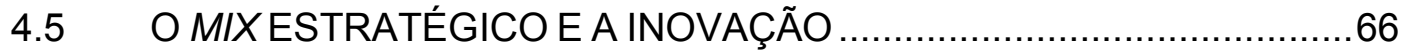

4.5.1 ESTRATÉGIAS QUANTO À COMPETITIVIDADE ..........................67

4.5.2 ESTRATÉGIAS QUANTO AO PRODUTO E AO MERCADO 69

4.5.3 ESTRATÉGIAS QUANTO A UTILIZAÇÃO DOS MEIOS ……..........70

4.6 A INOVAÇÃO NA PEQUENA EMPRESA …....................................71

5 O TRABALHO DE CAMPO

5.1 APRESENTAÇÃO DO SETOR DE PESQUISA …….........................76

5.2 CRITÉRIOS DE CLASSIFICAÇÃO DA PEQUENA

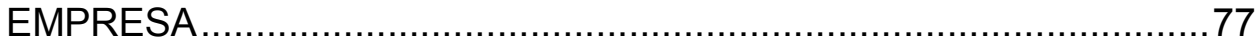

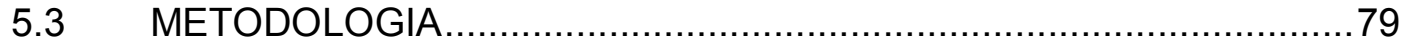

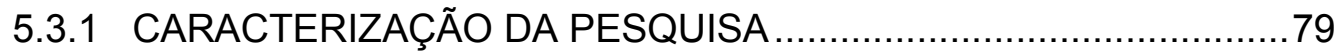

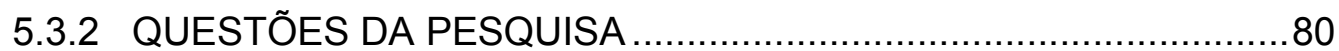

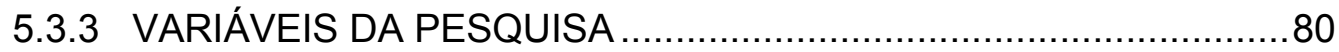

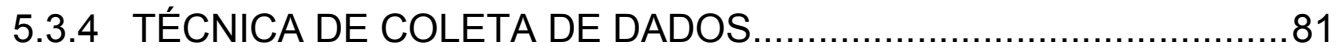

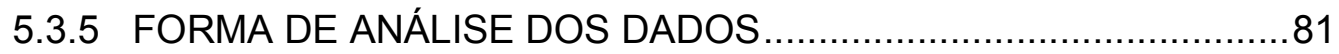

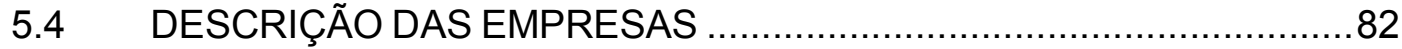

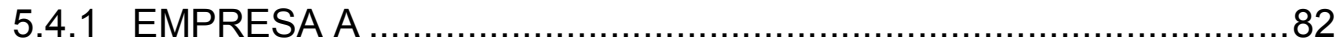

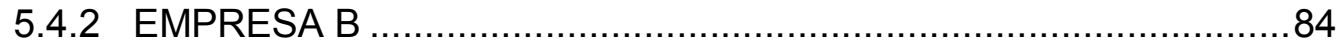

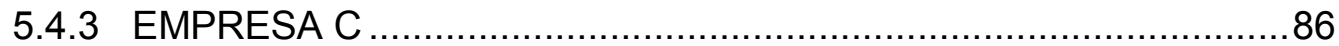

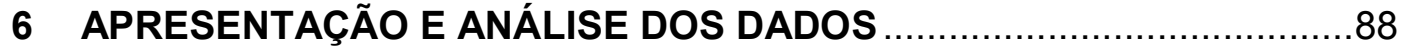

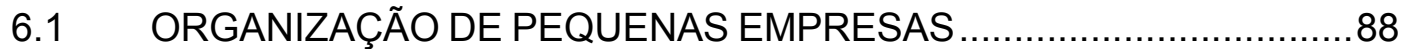

6.2 ESTILOS DE GESTÃO MAIS EVIDENTES NAS EMPRESAS .............94

6.3 COMO O GESTOR CONTRIBUI PARA O PROCESSO DE

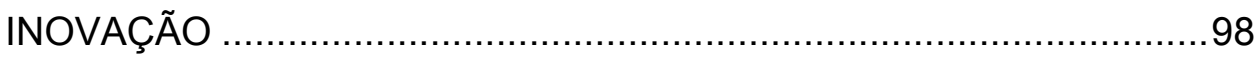

6.4 DE QUE FORMA A EMPRESA BUSCA ALCANÇAR E/OU MANTER SUA POSTURA INOVATIVA ….........................................101

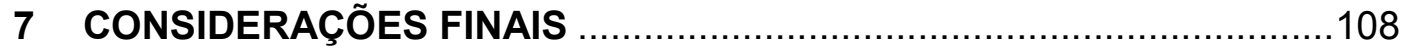

7.1 ORGANIZAÇÃO DE PEQUENAS EMPRESAS …...........................109

7.2 ESTILOS DE GESTÃO MAIS EVIDENTES NAS EMPRESAS ...........110 
7.3 COMO O GESTOR CONTRIBUI PARA O PROCESSO DE

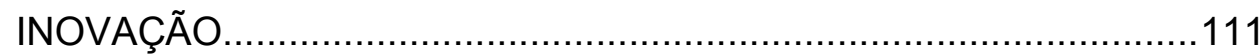

7.4 DE QUE FORMA A EMPRESA BUSCA ALCANÇAR E/OU MANTER SUA POSTURA INOVATIVA .............................................112

7.5 CONTRIBUIÇÕES DA PESQUISA, SUAS LIMITAÇÕES E SUGESTÕES PARA TRABALHOS FUTUROS.................................113

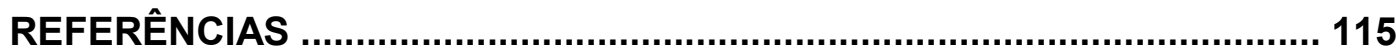

APÊNDICE A

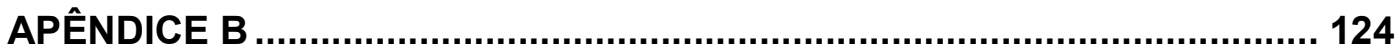





\section{CAPÍTULO I}

\section{INTRODUÇÃO}

Os mercados consumidores estão, cada vez, mais demandando produtos não massificados e de alta qualidade, obrigando, com isso, as empresas a implantarem uma cultura de melhoria contínua em seus processos de desenvolvimento e produção. Canais de distribuição antes inimagináveis, tais como a internet, lançam as empresas em uma competição em escala mundial. Novas técnicas, como o Just in $\operatorname{Time}^{1}$ e a produção enxuta, têm surgido como medidas para solucionar alguns dos problemas atuais que atingem a produção, trazendo em si várias alterações nos processos de trabalho, reduzindo estoques e produção ao nível de demanda, otimizando o uso de recursos e reduzindo os custos. Como, então, tornar a empresa moderna mais competitiva, neste cenário dinâmico em que seus consumidores conseguem, ao mesmo tempo, impor preços e exigir alta qualidade dos produtos, achatando, com isso, sua margem de contribuição devido à impossibilidade de redução nos custos? No atual contexto, para uma empresa ser competitiva, não basta ter eficácia operacional; entre outras coisas, é preciso ser diferente.

Torna-se necessário desenvolver e implantar métodos para aprimoramento da produção que não resultem somente em medidas de resultados numéricos. Deve-se inovar os processos e incluir, na estratégia das

\footnotetext{
${ }^{1}$ Técnica que visa produzir bens e serviços exatamente no momento em que são necessários (SLACK, N. , 1999 p.355).
} 
empresas os fatores inovação e aprendizagem como filosofias a serem disseminadas por toda a organização.

Além disso, de acordo com Naisbitt (1999, p.48), "quanto mais cresce a economia mundial, mais poderosos ficam seus protagonistas menores, e grandes organizações estão se fragmentando para tornarem-se confederações de pequenas empresas. A economia global está crescendo enquanto o tamanho das partes está encolhendo. No futuro, será cada vez mais difícil para as grandes empresas competirem com empresas menores, porque a cooperação e a competição tornaram-se o yin e o yang do mercado global”. O avanço tecnológico, a quebra de barreiras entre os países e a nova ordem mundial permitem que produtos possam ser produzidos em qualquer lugar do mundo, por empresas de qualquer parte do planeta e que focam o globo como um único mercado. A remoção de barreiras comerciais abriu caminho para as pequenas empresas e está tornando as unidades de negócios cada vez menores e mais ágeis.

\subsection{CARACTERIZAÇÃO DO TEMA DE PESQUISA}

Uma nova abordagem da administração, desenvolvida para alcançar uma variedade de temas preocupantes aos administradores de nosso tempo, tais como o acelerado ritmo do avanço tecnológico e a sofisticação dos consumidores, pode ser chamada de abordagem da organização que aprende. Uma organização que aprende é aquela preocupada em criar, adquirir, transferir conhecimento e alterar comportamentos com base nesses novos conhecimentos. Os administradores que pretendem criar esse tipo de organização devem promover um ambiente próprio ao aprendizado e encorajador da troca de informações entre todos os membros da empresa. Sabendo que, em cada indivíduo, a criatividade é função de três componentes: a experiência acumulada, a capacidade de ter idéias criativas e a motivação, organizações modernas devem transcender antigos modelos de gestão e aprenderem a aprender (CERTO, 2003).

É nesse contexto em que estão inseridas as pequenas empresas e os empreendimentos. Segundo Bateman e Snell (1998), um tema guia os 
empreendedores à medida que eles equilibram recursos críticos e combinam elementos organizacionais: a busca por vantagens competitivas. Se a organização obtém vantagem, ela sobreviverá; se a vantagem for distinta, ela prosperará. Estratégias bem-sucedidas não requerem tecnologia de ponta ou um novo e único produto; mesmo empresas que oferecem os produtos mais comuns podem obter vantagens competitivas, criando produtos e serviços diferentemente e melhor que seus concorrentes, ou seja, inovando.

Assim, o tema desta pesquisa é "O Estilo de Gestão em Pequenas Empresas e a Inovação".

\subsection{FORMULAÇÃO DO PROBLEMA DE PESQUISA}

Porter (1998) afirma que, para as empresas, só é possível obter um alto retorno quando se adota ou uma estratégia de baixo custo ou uma estratégia de diferenciação; o meio-termo não é adequado. A primeira opção será possível somente quando se detém uma grande parcela de mercado, o que na grande maioria das vezes não se encaixa à pequena empresa. A segunda estratégia, de diferenciação, poderá emergir na pequena empresa adotando-se práticas que permitam a inovação.

De acordo com Schuler e Jackson (1995, p.4), para inovar é necessário pensar além das habilidades técnicas, dos conhecimentos e capacidades específicas e necessárias para executar alguma tarefa. Torna-se, portanto, mais útil pensar a respeito do que é necessário para estimular um funcionário comum que trabalha como outros num ambiente social e, assim, criar condições para a inovação. A inovação é uma estratégia possível para a competitividade das empresas. No entanto, nem todas as empresas conseguem inovar; entre as pequenas há um alta taxa de mortalidade e, entre as grandes, muitas "tradicionais" desaparecem, empurradas por outras gigantes.

Alguns autores dão uma boa gestão como razão da capacidade de inovação; outros dizem que não é qualquer tipo de gestão que leva à capacidade inovativa, mesmo se considerada boa. 
Então, deve haver um estilo de gestão mais adequado à postura inovativa. Desta forma, pode-se formular o seguinte problema de pesquisa:

Qual a influência do estilo de gestão na capacidade de inovação em pequenas empresas?

\subsection{DECLARAÇÃO DOS OBJETIVOS DA PESQUISA}

O objetivo geral desta pesquisa é avaliar os estilos de gestão encontrados nas pequenas empresas, identificando quais de seus componentes possuem efeito na postura inovativa dessas empresas.

Como objetivos específicos têm-se:

1) revisar a literatura sobre gestão da inovação em produtos e processos;

2) revisar a literatura sobre estilo de gestão;

3) revisar a literatura sobre a pequena empresa;

4) verificar empiricamente como as pequenas empresas consideram suas vantagens competitivas na hora de definir suas estratégias de inovação;

5) confrontar o estilo de gestão das empresas com suas práticas inovadoras, identificando as dificuldades e possibilidades de sua disseminação.

\subsection{JUSTIFICATIVA}

As micro e pequenas empresas possuem um papel extremamente importante no contexto sócio econômico mundial e podem ser identificadas como um poderoso fator de promoção social, base de estabilidade política e força propulsora de desenvolvimento. Citada por Terence (2002 p.58), a Pesquisa Nacional por Amostra de Domicílios, realizada pelo IBGE (2000), constatou que existem no Brasil cerca de 3,5 milhões de empresas, das quais $98 \%$ são de micro e pequeno porte.

O tema desta pesquisa se insere no contexto das práticas administrativas atuais das pequenas empresas e na evolução da Teoria da Administração para o século XXI, partindo do pressuposto de que as pequenas empresas possuem particularidades na sua administração que as diferenciam 
das grandes corporações, principalmente no aspecto estratégico e que o processo de inovação exerce um papel importante na eficácia dessas estratégias. Dessa forma, a relevância da pesquisa está na identificação dos mecanismos presentes nas pequenas empresas inovadoras que alcançam sucesso, e em divulgar práticas que contribuam para o alcance dos objetivos organizacionais desse segmento.

\subsection{ESTRUTURA DO TRABALHO}

Com o objetivo de facilitar a leitura e orientar o leitor, a macro estrutura do trabalho é apresentada a seguir:

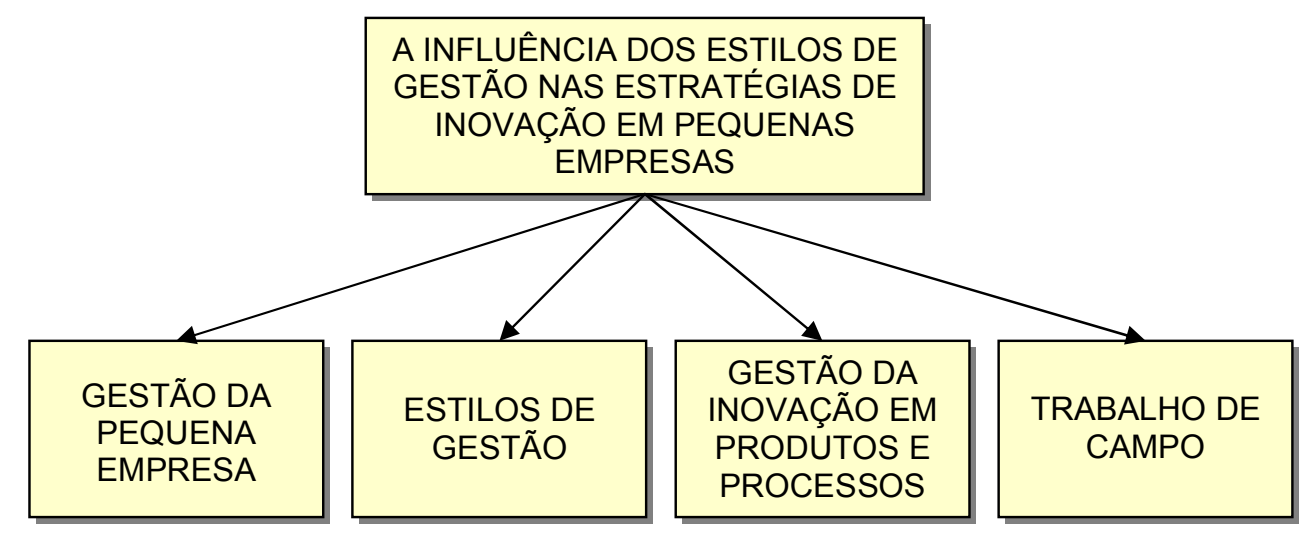

Figura 1: Estrutura da pesquisa

Nesta introdução, que compõe o capítulo 1, foram apresentados os tópicos: caracterização do tema de pesquisa, formulação do problema de pesquisa, declaração dos objetivos da pesquisa e justificativa.

No capítulo 2, Gestão da Pequena Empresa, são apresentados, entre outros, os critérios de classificação da pequena empresa, as dificuldades da pequena empresa no Brasil, as formas de organização e de exercício de poder 
e, por fim, são dadas algumas considerações acerca das técnicas administrativas a serem desenvolvidas para a pequena empresa.

O capítulo 3 apresenta as características e estilos de gestão encontrados na literatura sobre o assunto, por meio das mais importantes teorias já desenvolvidas.

A relevância da inovação, o processo de aprendizagem e a gestão do conhecimento são evidenciados no capítulo 4 , onde a necessidade de se estabelecer uma estratégia competitiva para as empresas começa a ser delineada.

O capítulo 5 apresenta o trabalho de campo, trazendo a metodologia, com a caracterização da pesquisa, as questões da pesquisa e suas variáveis, a técnica de coleta de dados e a forma de análise dos resultados.

Por fim, a apresentação e análise dos dados estão dispostas no capítulo 6, e algumas considerações finais são feitas no capítulo 7. 


\section{CAPÍTULO II}

\section{GESTÃO DA PEQUENA EMPRESA}

Segundo artigo intitulado: "Pequenos Negócios e Desenvolvimento", publicado em 5 setembro de 2002, resultante da jornada de discussões ${ }^{2}$ organizada pelo Instituto de Estudos do Trabalho e Sociedade, patrocinada pela Associação Brasileira dos Sebrae Estaduais e pelo Sebrae Nacional, os empreendimentos de pequeno porte são responsáveis pela geração significativa de postos de trabalho em todas as economias abertas do mundo.

Na América Latina, o segmento é atualmente responsável por metade das ocupações remuneradas e, no Brasil, 35 milhões de pessoas estão ocupadas em setores informais da economia e em micro e pequenas empresas.

O desemprego estrutural é considerado um dos maiores problemas enfrentados pela maioria das economias capitalistas. A incorporação da automação no setor produtivo gerou grande aumento de qualidade $\mathrm{e}$ capacidade produtiva, extinguindo-se grande quantidade de postos de trabalho.

Tal qual o Brasil, Bygrave ${ }^{3}$ apud Fowler (1998) cita que, nas companhias listadas, durante o período de 1988 a 1990, pela revista americana Fortune $500^{4}$, perdeu-se em torno de um milhão de empregos e, nos anos 90 ,

\footnotetext{
${ }^{2}$ A jornada de discussões teve como participantes, entre outros: André Urani (IE-UFRJ e IETS), Celina Vargas do Amaral Peixoto (Sebrae-RJ) Francisco Ferreira (PUC-RJ e IETS), Naércio Menezes Filho (USP) e Wilson Suzigan (Unicamp).

${ }^{3}$ BYGRAVE, W.D. (1994). The Portable MBA in Entrepreneurship. New York: John Wiley e Sons Pub.

${ }^{4}$ Pesquisa de grande impacto e credibilidade, divulgada pela revista americana Fortune, semelhante à divulgada pela revista brasileira EXAME.
} 
demitiu-se, em média, 300.000 trabalhadores por ano. Por outro lado, ainda nos Estados Unidos, as pequenas indústrias com menos de 20 trabalhadores adicionaram mais 100.000 empregos ao ano, a partir de 1990. Cita também que, atualmente, apenas $5 \%$ da força de trabalho dos Estados Unidos está empregada pelas grandes empresas listadas pela revista Fortune 500.

Considerando-se que a teoria administrativa e suas ferramentas foram desenvolvidas tendo em vista a aplicação em grandes empresas e que a pequena empresa possui características próprias, torna-se clara a necessidade de desenvolvimento de novas técnicas, adequadas às particularidades da pequena empresa, que proporcionem o auxílio necessário para a ampliação do nível de competitividade deste segmento, dada a sua relevância no mercado global.

\subsection{DIFICULDADES DA PEQUENA EMPRESA NO BRASIL}

De acordo com Mattar (1988), existe nas empresas uma obsessão universal pelo crescimento, acompanhada por uma idolatria do gigantismo, que se espalha por todos os ramos de atividade. Há uma crença generalizada de que o que é grande é melhor e mais eficaz, entretanto, o que se observa na atividade econômica é que essa crença não é verdadeira. Para certas atividades econômicas, as grandes empresas são mais eficazes; no entanto, do ponto de vista econômico-social, na grande maioria das atividades as pequenas e médias empresas são mais eficazes. Há também muitas empresas que abandonam a estratégia para crescer, perdendo suas vantagens competitivas.

O que preocupa é saber por que os índices de mortalidade das pequenas empresas são tão elevados. Mattar (1988) cita motivos de ordem externa e também motivos internos. Os externos ocorrem no meio ambiente da empresa, estão fora de seu controle e lhe dificultam a sobrevivência. Já os internos dizem respeito aos seus pontos fracos e também contribuem para reduzir sua sobrevivência.

Dentre os motivos externos, há o "efeito sanduíche", que ocorre para aquelas que compram de grandes fornecedores e vendem para grandes 
clientes. A pequena empresa nesta situação tem grandes dificuldades de sobreviver, pois os preços de compra são impostos pelos fornecedores e os de venda pelos clientes e, no meio desse "sanduíche", acabam sendo devoradas.

Paralelamente a estas grandes dificuldades externas, a pequena empresa possui grandes problemas de ordem interna. Dos motivos internos, um dos que mais a prejudica é a sua baixa capacidade de adaptação a mudanças no seu meio ambiente.

Um segundo motivo interno é a estreita vinculação empresa-empresário, pois, nas pequenas empresas não há separação entre a figura do empresário e a da empresa, a qual é dirigida segundo os objetivos pessoais do empresário. A empresa é utilizada para lhe dar "status" social e administrada de forma emotiva. Os bens da empresa se confundem com os do empresário. Quando a empresa vai bem, o empresário a descapitaliza para atender os seus objetivos pessoais. Quando a empresa vai mal, o seu grande temor não é o de perdê-la e sim o de ser arrastado junto com ela.

O terceiro motivo diz respeito aos poucos recursos financeiros da pequena empresa. São raras as que dispõem de todo capital necessário para o seu bom funcionamento. Quando a margem de lucro com que opera for suficientemente elevada para pagar os custos de capital de terceiros, e ainda sobrar recursos para constituição de capital próprio, a empresa sobreviverá e se tornará adulta. Caso contrário, vira empresa "anã" e tenderá a desaparecer.

A falta crônica de recursos financeiros leva a empresa a não se adequar em capacidade produtiva e instalações; a não dispor de capital de giro para financiar seus estoques, produção e vendas; a não cumprir suas obrigações tributárias e até a perder o crédito na praça pelo não cumprimento dos seus compromissos financeiros.

Um quarto motivo estende-se ao proprietário, geralmente alguém com alguma especialidade profissional operacional, que resolveu abrir o seu próprio negócio, sem possuir nenhuma noção e sem nenhuma formação adequada. Essa fraqueza do pequeno empresário acaba criando infindáveis problemas para a empresa, tanto no seu dia-a-dia quanto no seu desenvolvimento: ausência de objetivos não realísticos, estrutura organizacional informal e inadequada, ausência total de sistemas administrativos e de controles. O tipo de liderança exercida é o autocrático e as decisões são todas centralizadas no 
empresário, o nível de informação sobre o mercado e sobre a concorrência é baixo, o que leva a inúmeras decisões erradas. Pelo mesmo motivo, não são feitas previsões de vendas e de resultados confiáveis, as ações da empresa estão voltadas exclusivamente para vendas, desconhecendo-se totalmente as modernas técnicas de marketing. Há má gestão financeira, dos estoques e má gestão da atividade produtiva.

Segundo pesquisa realizada pelo SEBRAE (2002), no período entre 1997 e 2000 foram reveladas elevadas taxas de natalidade e de mortalidade de empresas em todos os anos, com as médias situando-se em 19,4\% e 12,9\%, respectivamente. Em termos absolutos, isso significa que, em média, 682.817 novas empresas foram abertas e 453.465 empresas foram extintas por ano. Importante é ressaltar que o saldo é sempre positivo, uma vez que a taxa de natalidade é 1,5 vez superior à de mortalidade, ou seja, registrou-se um número sempre maior de empresas sendo abertas do que sendo fechadas.

Os dados a seguir são resultantes da pesquisa "Fatores Condicionantes e taxa de Mortalidade", realizada pelo SEBRAE em 1999:

1) Na maioria dos Estados pesquisados, tanto empresas em atividade quanto extintas, recorreram principalmente ao contador (46\%) para conduzir ou gerenciar as empresas, vindo a seguir as pessoas que conheciam o ramo de atividade (32\%) e SEBRAE (31\%).

2) Dificuldades na condução dos negócios: A falta de capital de giro foi apontada em $73 \%$ dos Estados que fizeram parte da pesquisa como a maior dificuldade na condução das atividades, juntamente com a carga tributária e a recessão econômica.

3) Segundo a maioria dos entrevistados: A empresa para ter sucesso deve possuir bom conhecimento do mercado onde atua (48\%). Ter um bom administrador (41\%) e fazer uso de capital próprio $(31 \%)$ também foram fatores considerados importantes para o sucesso do empreendimento.

Além de concentrar o maior número de empresas, as micro empresas apresentam também as maiores taxas de natalidade e de mortalidade. No ano de 2000 , cerca de $99 \%$ das empresas criadas são desse porte. A tabela a seguir resume a demografia das empresas no Brasil no ano de 2000: 
Tabela 1: Nascimentos e mortes das empresas no Brasil - 2000

\begin{tabular}{|c|c|c|c|c|c|}
\hline & \multicolumn{4}{|c|}{ Porte } & \multirow{2}{*}{ Total } \\
\hline & Micro & Pequena & Média & Grande & \\
\hline $\begin{array}{l}\text { Número de } \\
\text { empresas }\end{array}$ & 3.740 .764 & 104.990 & 21.062 & 5.259 & 3.872 .075 \\
\hline $\begin{array}{l}\text { Nascimentos } \\
\text { em } 2000\end{array}$ & 704.628 & 4.894 & 634 & 102 & 710.258 \\
\hline $\begin{array}{l}\text { Mortes em } \\
2000\end{array}$ & 453.976 & 3.235 & 672 & 107 & 457.990 \\
\hline $\begin{array}{l}\text { Mudança de } \\
\text { porte }\end{array}$ & -7.171 & 6.173 & 683 & 315 & 0 \\
\hline $\begin{array}{l}\text { Variação } \\
\text { líquida em } \\
2000\end{array}$ & 243.481 & 7.832 & 645 & 310 & 252.268 \\
\hline $\begin{array}{l}\% \text { de variação } \\
\text { líquida em } \\
2000\end{array}$ & $6,51 \%$ & $7,46 \%$ & $3,06 \%$ & $5,89 \%$ & $6,52 \%$ \\
\hline $\begin{array}{l}\text { Número de } \\
\text { empresas em } \\
2000\end{array}$ & 3.984 .245 & 112.822 & 21.707 & 5.569 & 4.124 .343 \\
\hline
\end{tabular}

Fonte: IBGE, Diretoria de Pesquisas, Departamento de Emprego e Rendimento (2004).

O trabalho: Demografia das Firmas Brasileiras, elaborado pelo Banco Nacional de Desenvolvimento Econômico e Social - BNDES em 2003 (SEBRAE, 2002), teve como objetivo fornecer um quadro da dinâmica recente de sobrevivência das firmas formais no Brasil, por porte e por região geográfica, fornecendo dados sobre a taxa de mortalidade e natalidade das empresas do referido setor. Os principais resultados foram: a participação das firmas com até 19 empregados, no ano de 2000, representava 93\% do total, $97 \%$ dos nascimentos e $99 \%$ das mortes. Em média, a cada ano, foram criadas 314 mil firmas e fechadas 219 mil. 
Uma das características das pequenas empresas é o seu relativo custo maior de administração, ditado pela pequena escala de operação. A pequena escala pode limitar, em muito, as ações ligadas à gestão da produção, marketing, finanças, recursos humanos etc. Pzysieznig (1998) afirma que o caminho mais eficiente para a superação deste entrave é, obviamente, além da racionalização de processos, o próprio crescimento da empresa.

Pzysieznig (1998) diz que o risco associado a empreendimentos nascentes pode elevar-se, sobremaneira, quando estiver vinculado a inovações tecnológicas, uma vez que estão sujeitas não só a insucessos de mercado como a insucessos técnicos. Por outro lado, conforme Porter ${ }^{5}$ (1990 apud PZYSIEZNIG, 1998, p. 10), as empresas de base tecnológica são as que apresentam maior potencial para geração de retornos e as nações mais competitivas têm buscado viabilizar a constituição deste tipo de empresas, tanto em função de sua maior rentabilidade, quanto à natureza dos empregos que geram, mais exigentes em relação à qualificação dos recursos humanos e mais bem remunerados.

Além das dificuldades inerentes à formação de novas empresas, o Brasil tem, como agravante, altas taxas de juros, fortes inibidoras do investimento, mormente em projetos que apresentem um nível maior de risco. Desta forma, a menos que o pequeno empreendedor apresente um significativo conjunto de garantias patrimoniais, ou que mobilize e arrisque seu próprio patrimônio, o investimento privado em novas empresas tende a ter um volume bastante reduzido em relação ao considerado ideal.

\subsection{ORGANIZAÇÃO NAS PEQUENAS EMPRESAS}

\subsubsection{ORGANIZAÇÃO DO TRABALHO}

Os avanços na indústria automobilística no começo do século $X X$ trouxeram mudanças significativas para as organizações. Citado por Tedlow (2002), para que o automóvel se tornasse um produto de massa, Henry

\footnotetext{
${ }^{5}$ PORTER, MICHAEL E. (1990). The competitive advantage of nations. Free Press: N.Y.
} 
Ford implantou, entre 1913 e meados de 1914, a linha de montagem móvel em sua fábrica de Highland Park, racionalizando ao máximo o trabalho. Ford parcelou as tarefas e, assim, cada operário tornou-se responsável por um pequeno número de atividades, executadas por meio de gestos simples e repetidos, incessantemente durante uma jornada de trabalho. A ligação entre os vários trabalhos era feita pela linha de montagem.

O elemento que faltava para completar o que ficou conhecido como modelo fordista era a padronização das peças. Conforme citado por Maximiniano (2004, p.56), uma quantidade qualquer de um mesmo componente passou a ter uma medida exata e pôde ser, então, montado em qualquer automóvel. Com esse procedimento, Ford eliminou o tempo desperdiçado na adaptação dos componentes ao automóvel, como faziam os extintos operários qualificados. A divisão do trabalho implicou a especialização do trabalhador.

Nascia assim uma nova organização do trabalho, sendo o fordismo implantado fortemente na Europa e no Japão, depois de 1940, como parte do esforço de pós-guerra. Consolidou-se e expandiu-se por meio de políticas impostas na ocupação, ou do investimento direto americano, subseqüente. Essa abertura do investimento estrangeiro e do comércio permitiu que a capacidade produtiva excedente dos Estados Unidos fosse absorvida, ao mesmo tempo em que o sucesso do fordismo formava mercados de massa globais.

"Em todos os lugares onde eram pouco desenvolvidos, notadamente na Europa e no Japão, e toda vez que o podem ser, são os procedimentos doravante "clássicos" de organização do trabalho que são introduzidos: taylorismo, fordismo, sistemas de trabalho que incitam à produção". (BEAUD, 1999, p.315).

Logo depois da guerra, o presidente da Toyota, Kiichiro Toyoda, declarou ser de vital importância alcançar os norte-americanos, caso contrário, sua indústria corria o risco de desaparecer do cenário econômico. Seu principal engenheiro, Taiichi Ohno, desenvolveu, durante as décadas de 50 e 60, uma série de inovações, cujo conjunto ficou conhecido como lean production (produção enxuta ou produção flexível), pela eficiente capacidade de elevação da produtividade na indústria automobilística. 
O aumento da demanda trouxe mais inovações tecnológicas e novas formas organizacionais, originando o denominado just-in-time - JIT - sistema de produção descentralizado e flexível, capaz de controlar estoques e suprimentos. Um dos aspectos do JIT é a multifuncionalidade dos operadores, que nada mais é do que um movimento contrário à especialização do trabalhador.

De acordo com Sabbag (2000, p.3), as transformações a que assistimos nos dias de hoje são uma ameaça à sobrevivência das organizações e encontram-se amplificadas por um contexto que apresenta maior competitividade, agora no plano global. Ficou difícil projetar tudo o que pode ocorrer devido à ausência de regras claras. Por isso, cresce a complexidade da gestão com diversos paradigmas entrando em crise, e o próprio taylorismo requer maior sofisticação de processos, da organização e de sistemas gerenciais. A tecnologia da informação provoca modificações na organização do trabalho, com alteração de cargos, profissões, rotinas e mesmo a relação entre pessoas, fazendo com que empregos convivam com outras formas de trabalho.

Essa breve exposição de algumas das diversas formas de organização da produção teve a intenção de demonstrar que: seja a empresa focada nos princípios de Taylor ou nas técnicas de Taiichi Ohno, essas formas de organização possuem grande influência na motivação dos trabalhadores de hoje e, por conseqüência, na capacidade inovativa das organizações. Portanto, cabe um maior aprofundamento nas relações de comando, presentes nessas organizações, podendo remeter ao estilo dos gestores atuais, o que irá enriquecer o núcleo central de nossa pesquisa.

\subsubsection{COORDENAÇÃO DO TRABALHO}

Mintzberg (2003, p.14) aponta como sendo cinco mecanismos de coordenação:

a) ajuste mútuo: obtém a coordenação do trabalho pelo simples processo de comunicação informal. $O$ controle do trabalho permanece na mão dos operários. 
b) supervisão direta: quando uma pessoa passa a ser responsável pelo trabalho de outras. Surge quando ajustes mútuos não são suficientes para coordenar o trabalho.

c) padronização dos processos de trabalho: quando o conteúdo do trabalho for especificado ou programado.

d) padronização dos resultados do trabalho: a coordenação das tarefas é predeterminada e os resultados são especificados.

e) padronização das habilidades dos trabalhadores: quando os trabalhadores são escolhidos de acordo com as habilidades que possuem para o exercício das tarefas exigidas pelo cargo.

O autor declara que, à medida que o trabalho organizacional torna-se mais complicado, o ajustamento mútuo não se torna adequado e surge a padronização dos processos de trabalho.

A formalização do trabalho surge como forma de reduzir sua variabilidade e também para prevê-lo e controlá-lo, mas empobrece seu conteúdo quando tira do trabalhador a possibilidade de realizá-lo de acordo com as suas próprias aptidões e habilidades. Cabe aqui destacar duas definições em relação à presença ou não da formalização do comportamento, das quais emerge o conceito das estruturas burocráticas e das orgânicas.

Estruturas burocráticas são aquelas que confiam na formalização do comportamento como forma de obterem coordenação. Já as estruturas orgânicas enfatizam os arranjos flexíveis baseados no ajustamento mútuo ou na supervisão direta. Ambas encontram-se nos dois extremos do continuum da padronização.

Sabbag (2000) apresenta críticas em relação à estrutura burocrática e seu efeito danoso sobre a capacidade de inovação, dizendo que a primazia das regras faz vigorar a impessoalidade; a busca de eficiência suplanta a de eficácia; o desejo da reprodutibilidade requer uma ação desprovida de crítica, como se toda a razão já houvesse sido aplicada quando da criação da regra.

De acordo com Mintzberg (2003), a padronização ocorre mais no núcleo operacional, com os membros que executam o trabalho diretamente relacionado à fabricação dos produtos e à prestação dos serviços, como forma de proteger as operações de distúrbios externos. Embora alguns trabalhadores 
prefiram trabalhos repetitivos e estreitamente padronizados, a ampliação do trabalho compensa na extensão em que ganhos, decorrentes de trabalhadores mais motivados, compensam as perdas da especialização técnica menos otimizada.

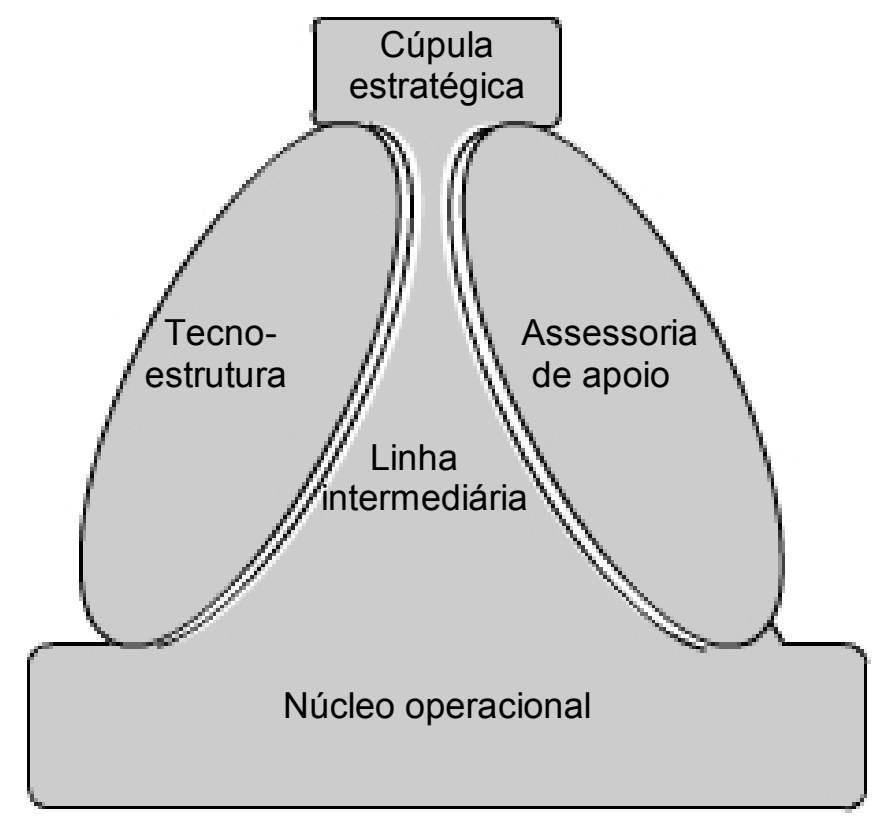

Figura 2: As cinco partes básicas da organização.

Fonte: MINTZBERG, H. (2003)

\subsubsection{DESCENTRALIZAÇÃO DE DECISÕES}

De acordo com Bateman e Snell (1998, p.248), a estrutura evidenciada pelo organograma da empresa não descreve, na maioria dos casos, como a empresa realmente funciona. Mesmo que se tenha o conhecimento sobre os relacionamentos de autoridade há de se entender quem realmente influencia quem, quais são os administradores mais poderosos, quais os grupos são mais eficazes, quem interage com quem. Essas questões terão grande influência no comportamento de seus funcionários. A descentralização surge como forma de delegação de responsabilidade e autoridade para a tomada de decisões. Numa organização com esse perfil, as decisões são tomadas em níveis mais baixos 
por pessoas que são mais diretamente afetadas e possuem conhecimento mais apurado do problema. A descentralização torna-se importante quando o ambiente de negócios modifica-se rapidamente e as decisões têm que ser tomadas com qualidade e rapidez.

Uma questão então é levantada por Mintzberg (2003, p.113): "Por que descentralizar a estrutura visto que a centralização é o meio mais seguro de coordenar a tomada de decisão na organização"?

Primeiro: porque nem todas as decisões conseguem ser entendidas em um centro, em um único núcleo pensante. Segundo: porque a descentralização traz flexibilidade à organização por permitir respostas rápidas em condições locais e, por fim, porque ela constitui um estímulo para a motivação.

Conforme ilustrado na Figura 3 a seguir, um processo de decisão mais descentralizado é aquele em que o tomador de decisão controla apenas a fase da escolha (BATEMAN e SNELL, 1998, p.95).

A descentralização pode ocorrer em duas dimensões e sua discussão torna-se relevante sob o aspecto de delegação de poder:

a) descentralização vertical: diz respeito à delegação de poder de tomada de decisão aos escalões inferiores da cadeia de autoridade, da cúpula estratégica para a linha intermediária.

b) descentralização horizontal: transferência de poder dos gerentes aos nãogerentes.

A descentralização somente poderá ser considerada completa quando o poder não for baseado em cargo ou conhecimento, mas sim na filiação: todos participam igualmente da tomada de decisão, tornando a organização democrática e favorecendo a motivação das pessoas.

Para finalizar a questão estrutural, na próxima seção são apresentadas as cinco estruturas descritas por Mintzberg (2003), com a devida ênfase em seus efeitos sobre o poder e a motivação dos indivíduos. 


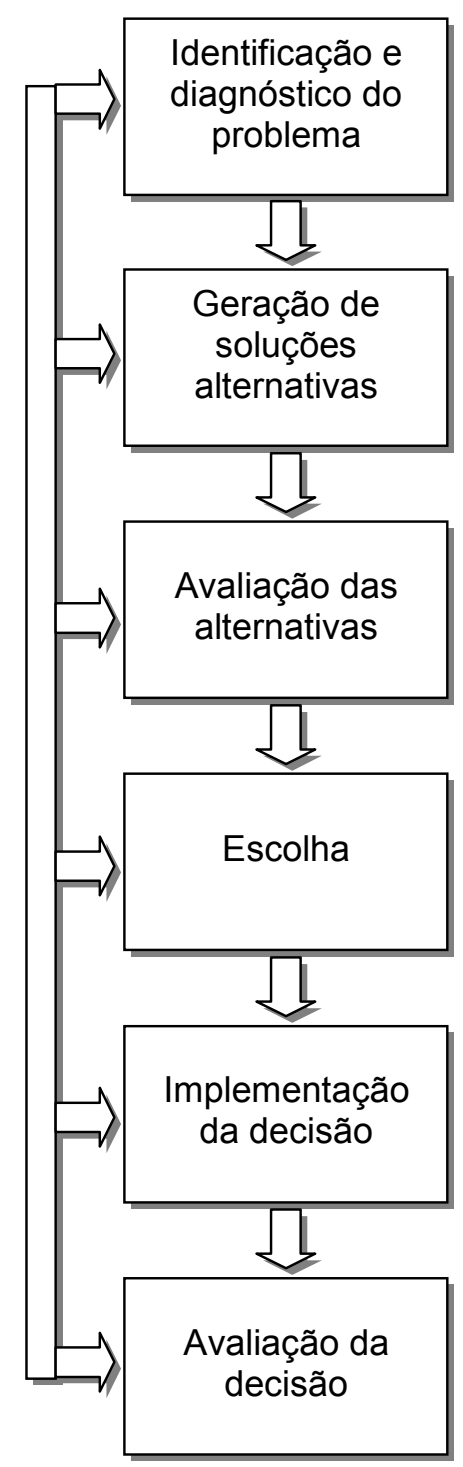

Figura 3: Os estágios da tomada de decisão

Fonte: Bateman e Snell (1998, p.95).

\subsubsection{AS CINCO ESTRUTURAS DE MINTZBERG}

As cinco partes básicas da organização, de acordo com Mintzberg, já foram apresentadas na Figura $2 \mathrm{e}$, embora uma discussão prévia sobre o comportamento do núcleo operacional tenha sido feita, é necessário que haja uma análise ressaltando as cinco forças que impulsionam a organização. 
Emergem daí as cinco configurações de estruturas a seguir:

a) A estrutura simples: caracterizada como uma estrutura orgânica em que o poder é centralizado por meio de supervisão direta. Sua ocorrência predomina em organizações pequenas, com sistema técnico simples e dinâmico. Pouco de seu comportamento é formalizado e há baixa aplicação de planejamento. É importante observar que o fluxo de informação flui informalmente nessa estrutura e há grande flexibilidade e rapidez na tomada de decisão, em função da centralização do poder. A estratégia emerge diretamente das crenças pessoais de seu dirigente máximo e torna-se uma extensão de sua personalidade. Muitas das pequenas organizações permanecem com essa estrutura e o caso clássico de organização simples é aquela dirigida pelo proprietário, com características de empresa empreendedora. A estrutura simples é considerada a mais arriscada das estruturas por depender diretamente da saúde e dos caprichos de um indivíduo.

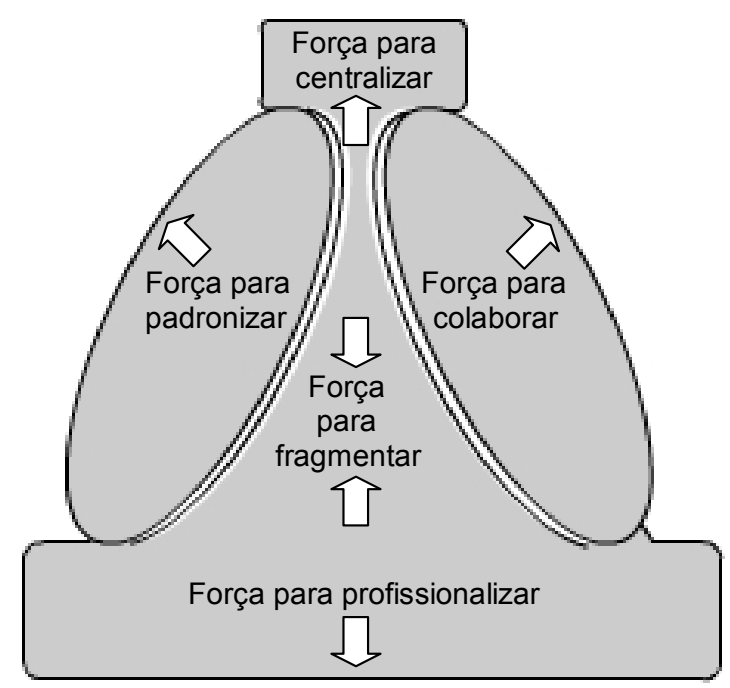

Figura 4: As cinco forças que impulsionam a organização.

Fonte: MINTZBERG, H. (2003).

b) A burocracia mecanizada: enfatiza a padronização dos processos de trabalho, formaliza o comportamento e possui centralização vertical e 
descentralização horizontal limitadas. Sua ocorrência é possível em ambientes simples e estáveis e seu nascimento reporta à Revolução Industrial. Nela, a comunicação formal é favorecida em todos os níveis e a tomada de decisão tende a seguir a cadeia de autoridade formal. A burocracia mecanizada é uma estrutura com obsessão pelo controle, usado principalmente para conter os conflitos com os quais ela é dominada, em virtude de seu design. Quando tarefas simples e repetitivas devem ser desempenhadas, a burocracia mecanizada é a estrutura mais eficiente, porém, sua obsessão pelo controle gera uma série de problemas humanos ao destruir o significado do próprio trabalho para os indivíduos. Também surgem problemas de coordenação uma vez que o núcleo operacional não está preparado para lidar com conflitos e seus reflexos acabam por afetar sua estrutura administrativa.

c) A burocracia profissional: busca a padronização com descentralização, tanto horizontal quando vertical, focando na padronização das habilidades, fazendo com que todos confiem no conhecimento de seus profissionais para produção de produtos ou serviços padronizados. A coordenação dessa padronização das habilidades ocorre por meio do treinamento e da doutrinação. A burocracia profissional enfatiza a autoridade de natureza profissional - o poder do conhecimento especializado. É democrática ao disseminar poder diretamente a seus trabalhadores profissionais, dandoIhes autonomia, o que permite o aperfeiçoamento de suas habilidades. Alguns problemas, porém, devem ser destacados nessa estrutura, em função de sua própria natureza democrática e autônoma, pois ela não pode lidar facilmente com profissionais incompetentes que ignoram as necessidades de seus clientes e da própria organização. Sua estrutura inflexível apresenta problemas de ajustamento para a produção de novos produtos, e a inovação é dificultada pelo pensamento convergente em que novos problemas são forçados a se adaptarem às antigas categorizações. O trabalho complexo não pode ser executado com eficácia, a menos que esteja sob controle do operador que o executa. 
d) A forma divisionalizada: possui descentralização vertical limitada e ocorre em mercados diversificados. Possui necessidade de poder dos gerentes intermediários e não constitui uma estrutura completa, que vai da cúpula estratégica ao núcleo operacional, mas é uma estrutura sobreposta a outras. Cada divisão tem sua própria estrutura e opera como entidade semi-autônoma, livre da coordenação como as outras unidades. O escritório central proporciona ampla autonomia para que as divisões tomem suas próprias decisões, desenhando o sistema de controle de desempenho e monitorando somente o resultado dessas decisões. Essa estrutura funciona melhor com as estruturas mecanizadas em suas divisões. De grande ocorrência em corporações muito grandes, esta estrutura apresenta riscos ao concentrar muito poder em poucas mãos.

e) A Adhocracia: seu principal mecanismo de coordenação é o ajustamento mútuo, definido no item 2.2.2. Possuindo estrutura orgânica e descentralização seletiva, a especialização horizontal do trabalho, nessa estrutura, é favorecida por ambientes complexos e dinâmicos. A Adhocracia possui a tendência de agrupamento dos especialistas das diversas unidades funcionais em pequenas equipes de projetos, envolvendo gerentes de linha, especialistas operacionais e assessores. Das cinco configurações apresentadas ela é a que menos se alinha com os princípios clássicos da administração, principalmente em relação à unidade de comando. A Adhocracia deve dar poder aos especialistas, não confiando nas habilidades padronizadas desses especialistas para obter a coordenação e, sim, estimulando a combinação de conhecimentos e habilidades existentes, por meio das equipes multidisciplinares formadas em torno de projetos específicos.

Mintzberg (2003) também divide a Adhocracia em Operacional e Administrativa. Os clientes são o foco da primeira e a própria estrutura é o foco da última, o que separa o componente administrativo do núcleo operacional, ficando o administrativo na forma de uma Adhocracia e o operacional, desconectado das outras partes. Diante de um problema do cliente, a Adhocracia Operacional reúne esforços criativos para apresentar uma nova 
solução, o que a faz diferente da burocracia profissional quando esta classifica o problema em uma categoria conhecida e aplica uma solução padronizada.

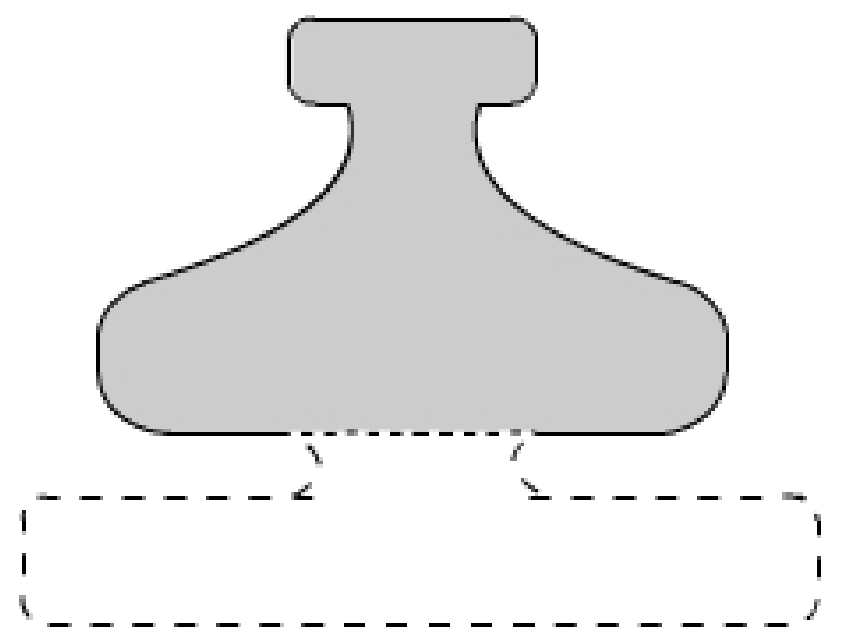

Figura 5: Adhocracia

Fonte: Mintzberg (2003, p.291).

O trabalho operacional e administrativo tendem a fundirem-se num esforço único, sendo difícil separar o planejamento do trabalho de sua execução. Nas Adhocracias, o poder de tomada de decisão é amplamente distribuído entre pessoal gerencial e não gerencial, de todos os níveis hierárquicos. Um híbrido entre Adhocracia Operacional e Estrutura Simples é denominada pelo autor como Adhocracia Empreendedora. Surge nas pequenas empresas caracteristicamente empreendedoras, o que as torna interessantes para o propósito deste trabalho.

Embora a estrutura apresente inúmeras colocações importantes, Mintzberg (2003, p.306) enfatiza que são necessárias condições naturais para sua adoção e que, uma vez implantada em um ambiente simples e estável, ela se tornaria artificial e desagradável para seus participantes, uma vez que não é adequada para tarefas comuns.

Embora a estrutura simples possa inovar, a Adhocracia possui a capacidade de inovações mais sofisticadas por reunir especialistas com múltiplos conhecimentos em equipes de projetos que funcionam regularmente. 


\subsubsection{ASPECTOS DA GESTÃO NA PEQUENA EMPRESA}

Embora os gerentes tanto de empresas grandes quanto de pequenas, desempenhem funções gerenciais similares, seu trabalho como gerentes é um tanto diferente. Isso é reconhecido prontamente por um gerente que se muda de uma empresa grande para uma pequena. Ele encontra uma atmosfera empresarial totalmente diferente. Além disso, as empresas pequenas sofrem constantes mudanças em suas necessidades organizacionais e gerenciais, à medida que se movem do ponto zero, de sua fundação, para o ponto em que podem empregar todo um staff de administradores profissionais (LONGENECKER, MOORE e PETTY, 1997).

Segundo Resnik (1990), quando os proprietários-gerentes de pequenas empresas compreendem os fatores básicos que causam o sucesso ou o fracasso da empresa, seus conceitos administrativos os ajudam a superar as dificuldades, inevitáveis, encontradas em todos os empreendimentos.

Um importante estudo feito por Filion (1999) classifica os gerentesproprietários de pequenos negócios em empreendedores e operadores, ambos com seus próprios sistemas de atividades. Para os empreendedores, as atividades no sistema foram: visão, projeto, animação, monitoração e aprendizagem, enquanto para os operadores foram: seleção, desempenho, atribuição, alocação, monitoração e ajuste. Ele salienta a ausência de trabalhos acerca do processo gerencial que tenham sido obtidos a partir de estudos empíricos e, embora já se tenha dito sobre as diferenças no gerenciamento de pequenas empresas, em relação às grandes, poucos modelos surgiram com base em dados empíricos. A pesquisa descrita por Filion (1999) mostra que os métodos gerenciais dos gerentes-proprietários não seguem a lógica formal demonstrada por Fayol: planejamento, organização, comando e controle.

Em relação à visão, foram identificadas três categorias. Primeiramente, a visão emergente - composta pelas idéias para futuros produtos e serviços.E seguida, a visão central - resultado de uma ou mais visões emergentes, e dividida em duas partes. A parte externa é composta pela faixa de mercado a ser ocupada por um produto ou serviço, e a parte interna pelo tipo de organização necessária a fim de tornar realidade o projeto. Por fim, a visão 
complementar - atividades gerenciais necessárias para dar suporte à concretização da visão central.

A Figura 6 ilustra os cinco elementos principais que irão fornecer a estrutura necessária para guiar as atividades dos empreendedores.

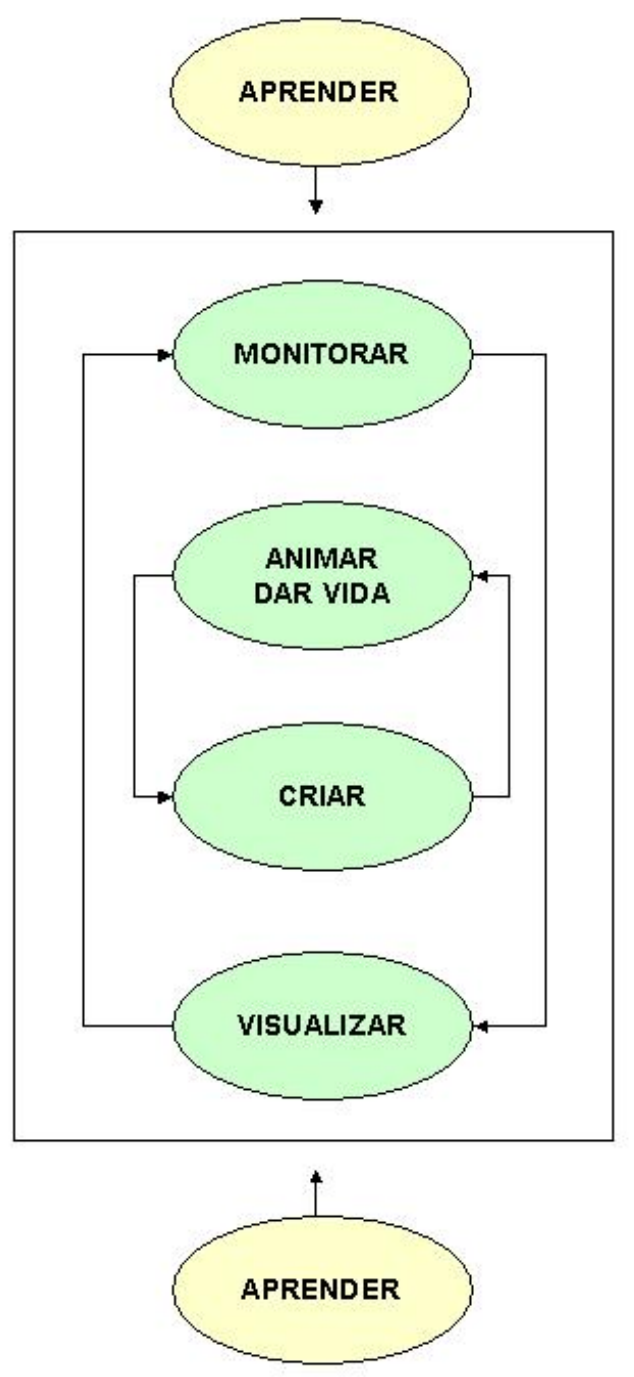

Figura 6: 0 processo gerencial dos empreendedores Fonte: FILION, L.J. (1999).

Ao projetar a arquitetura de negócios, a ênfase recai não sobre a produção, mas sobre a criação do produto e o marketing. A arquitetura imaginada pela maioria dos empreendedores bem-sucedidos, que foram entrevistados por Filion (1999), foi a de uma empresa original, tal empresa não 
obedecia às regras de uma estrutura hierárquica, o papel dos empregados era desenvolver um produto ou mercado, além de estruturar seu desenvolvimento sobre a autoridade de outra pessoa e prosseguir desenvolvendo outros produtos. Os gerentes-proprietários tornar-se-iam empreendedores, mais com o papel de animar, dar vida, do que com o de gerenciar. Suas presenças têm forte influência na relação entre criação e dinâmica e após um trabalho pronto, eles se deslocam ele se desloca para novas atividades, deixando as pessoas, treinadas e capacitadas, desenvolvendo o trabalho adequadamente. 


\section{CAPÍTULO III}

\section{CARACTERÍSTICAS E ESTILOS DE GESTÃO}

É notável como os temas que envolvem o comportamento humano sempre intrigaram os cientistas e pesquisadores, quer seja pela atração em entender sua própria natureza, quer pelo quanto esse assunto influencia diversos outros diretamente relacionados a ele como, por exemplo, o fenômeno da liderança.

De todas as funções de administração, a liderança parece ser a mais estudada e, talvez, a menos compreendida (HAMPTON, 1990, p.197).

Este capítulo demonstra, por meio dos principais autores de estudos sobre o assunto, que, do ponto de vista teórico, a pesquisa acadêmica vem tentando correlacionar o conceito de liderança às mais diferentes variáveis. Surgem daí várias preocupações de ordem prática, que têm motivado outras pesquisas com o objetivo de levantar os fatos que levaram alguns líderes a tornarem-se famosos, conduzindo suas organizações ao sucesso.

Hersey e Blanchard (1974, p.87) definem liderança como um processo de influenciar pessoas ou grupos, para a realização de um objetivo, em determinada situação. Portanto, liderança inclui a realização de objetivos com pessoas e por meio destas. Um líder deve ocupar-se de tarefas e realizações humanas. "Para ser um bom líder é preciso criar uma visão de grandiosidade para a unidade em questão, identificar e modificar aliados, adversários, os que ficam em cima do muro e também ter a coragem necessária para concretizar uma visão" (BATEMAN e SNELL, 1998, p.347). 


\subsection{A TEORIA DE TRAÇOS DE PERSONALIDADE}

Tida como a primeira sistematização dos estudos sobre liderança e tendo predominado até a década de quarenta, a Teoria dos Traços enfatiza as qualidades pessoais do líder. Seus pesquisadores sugeriam que os líderes deveriam possuir certas características de personalidade especiais que seriam as principais facilitadoras no desempenho do papel de liderança. Nesse enfoque, eles deveriam ser pessoas diferentes, cujos traços de personalidade seriam responsáveis não só por torná-los líderes como também por mantê-los em suas posições. Essa descrição tornaria os líderes natos, ou seja, pessoas que já nasceram com um dom especial de influenciar pessoas e reunir seguidores. Desta forma, não haveria técnicas possíveis de serem ensinadas a fim de que uma pessoa comum se tornasse um líder. Foram examinadas habilidades e características, tais como: inteligência, fluência verbal, escolaridade e conhecimento, bem como uma ampla gama de aspectos de personalidade (BRYMAN ${ }^{6}$ apud BERGAMINI, 1994, p.29).

De acordo com Hersey e Blanchard (1974, p.86), uma resenha das pesquisas sobre aqueles que utilizaram esse enfoque da liderança revelou poucos resultados significativos, pois, não foi possível chegar a um conjunto de qualidades de personalidade que poderiam ser usados para discriminar líderes de não-líderes. Estudos empíricos sugerem que a liderança é, na verdade, um processo dinâmico que varia de situação para situação, afetando líderes, seguidores e situações consequentemente, acredita-se em que todas as pessoas podem potencializar sua eficiência em papéis de liderança, por meio da educação, instrução e desenvolvimento.

\footnotetext{
${ }^{6}$ BRYMAN, A. (1992). Carisma and Leadership in organizations. London: SAGE Publications.
} 


\subsection{TEORIAS SOBRE ESTILOS DE LIDERANÇA}

Administradores líderes de negócios formam o recurso básico e mais escasso de qualquer empresa, podendo a maioria dos fracassos ser atribuída à liderança pouco eficiente (HERSEY e BLANCHARD, 1974, p.85). O comportamento dos líderes tem sido objeto de pesquisa há muito tempo e vários estudos consistentes apontam para duas variáveis importantes, de grande influência no desempenho de suas atividades: o "comportamento de relacionamento" e o "comportamento de tarefas". Tais comportamentos surgem como dois eixos de uma matriz que define o grau de importância dada pelo gestor as suas decisões, considerando a necessidade do cumprimento da tarefa e as necessidades de seus funcionários.

A liderança, segundo Douglas McGregor ${ }^{7}$ (1960 apud MAXIMINIANO, 2004, p.289) não é apenas um atributo da pessoa, mas também um processo social complexo, formado de quatro componentes básicos: as motivações dos liderados, a tarefa, o líder e a conjuntura ou contexto social em que ocorre a relação entre o líder e os liderados.

\subsubsection{A TEORIA DE HERSEY E BLANCHARD DO CICLO DE VIDA DA LIDERANÇA}

Hersey e Blanchard (1974, p.64), após constatarem que nos Estados Unidos, a maioria das pessoas era tratada em seu ambiente de trabalho, como seres humanos imaturos, desenvolveram uma série de estudos em organizações industriais para verificar quais os efeitos das práticas de administração no comportamento dos indivíduos e do seu crescimento pessoal dentro do ambiente de trabalho. Segundo eles, sete mudanças devem ocorrer na personalidade do indivíduo para que ele amadureça com o passar do tempo:

1) o indivíduo passa de um estado passivo, como um bebê, para um estado de crescente atividade, como adulto.

\footnotetext{
${ }^{7}$ MCGREGOR, D. (1960). The human side of enterprise. New York: McGraw-Hill.
} 
2) um indivíduo desenvolve-se de um estado de dependência em relação aos outros para um estado de relativa independência, como adulto.

3) como bebê, um indivíduo se comporta apenas de algumas formas, já como adulto pode se comportar de muitas formas diferentes.

4) como adulto, o indivíduo cria interesses mais profundos e intensos.

5) a perspectiva, enquanto criança, é muito limitada e, ao amadurecer, sua perspectiva de tempo aumenta a fim de incluir o passado e o futuro.

6) como um bebê, um indivíduo está subordinado a todos, mas adulto passa para posição igual ou superior.

7) como criança, um indivíduo não tem consciência do "eu", já como adulto não só tem essa consciência como é também capaz de controlar esse "eu."

Em muitas organizações espera-se que o operário atue de forma imatura. Eles são estimulados a serem passivos e subordinados e esta tendência para conservar as pessoas imaturas está implícita na natureza da organização formal, onde o poder e as decisões são colocadas nas mãos de poucas pessoas, instaladas na alta administração. Os que estão abaixo da corrente de comando são rigorosamente controlados e devem seguir as normas estabelecidas pelos seus superiores. Isso é incompatível com o desenvolvimento de uma personalidade madura.

Resgatando conceitos da escola de administração científica, com seu interesse por tarefa, e das relações humanas com interesse por relações pessoais, estudos realizados pelo Survey Research Center, da Universidade de Michigan, conseguiram identificar dois conceitos de liderança denominados “orientação para o empregado" e "orientação para produção". O líder orientado para o empregado enfatiza as relações humanas de seu trabalho, interessando-se por todos e aceitando suas individualidades e necessidades pessoais. Já o líder orientado para a produção acentua os aspectos técnicos do trabalho e considera os empregados como instrumentos para a realização dos objetivos da organização (HERSEY e BLANCHARD, 1974, p.91-92).

A Teoria do Ciclo de Vida da Liderança, de Hersey e Blanchard (1974) associa os estilos de liderança às várias situações, com base na maturidade do seguidor, ou seja, a capacidade para aceitar responsabilidades, bem como a educação significativa para a tarefa e experiência do indivíduo ou grupo. 
A teoria define que o estilo de liderança deve considerar o nível com que o liderado consegue desempenhar suas tarefas de maneira autônoma e, na medida em que o nível de maturidade dos seguidores de uma pessoa aumenta, o comportamento adequado desse líder altera-se, exigindo cada vez menos foco na tarefa, passando por um aumento no comportamento de relações, mas culminando com uma redução também destas relações.

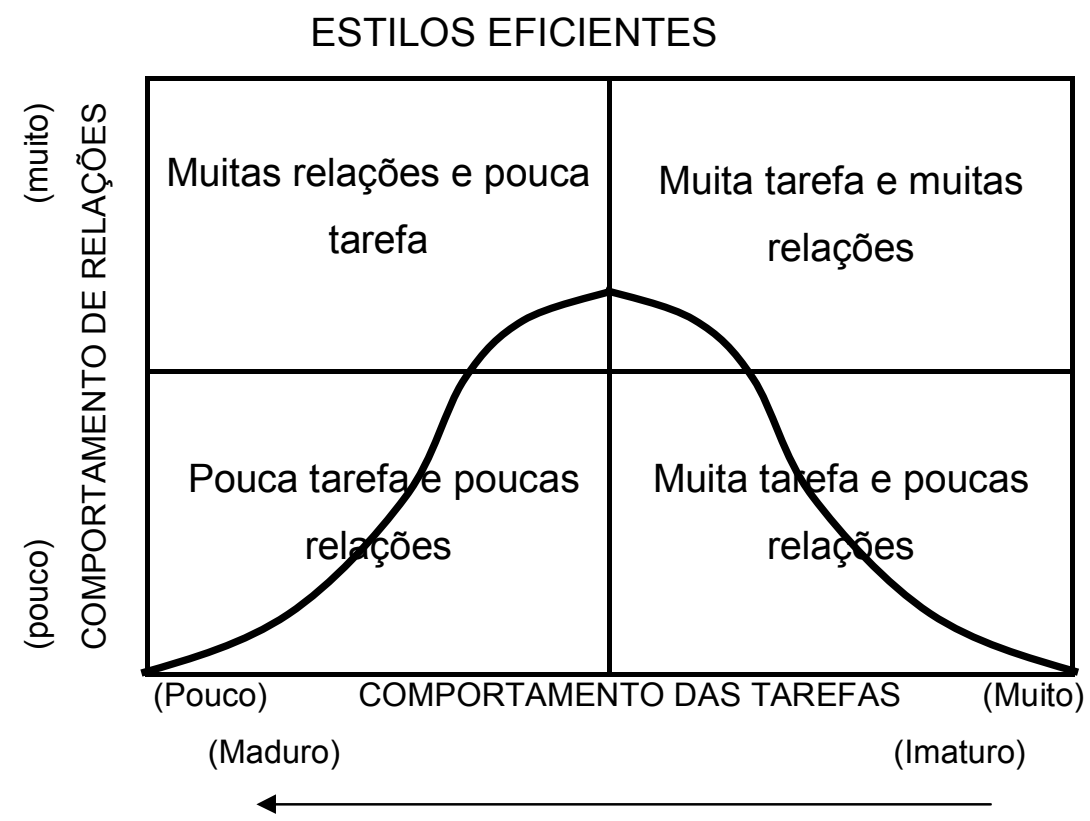

Figura 7: A Teoria do Ciclo Vital da Liderança.

Fonte: Hersey e Blanchard (1974)

\subsubsection{OS ESTUDOS DO INSTITUTE FOR SOCIAL RESEARCH}

Um programa de pesquisas, iniciado em grande escala no ano de 1947, pelo Institute for Social Research, com apoio do Serviço de Pesquisa Naval americano e da Fundação Rockefeller, entre outros, empreendeu uma série de estudos a fim de relacionar a estrutura organizacional e os principais métodos de liderança e administração que resultam numa melhor performance e desempenho organizacional. Anos mais tarde realizaram-se também experiências em outras companhias para aplicação e experimentação das 
descobertas dos estudos anteriores (LIKERT, 1979, p.19). Algumas conclusões gerais obtidas desses estudos apontam para um melhor desempenho quando supervisores focalizam atenção primeiramente sobre os aspectos humanos dos problemas de seus subordinados.

$\mathrm{Kahn}^{8}$ (1956 apud LIKERT, 1979, p.22) observou que os chefes das unidades mais produtivas não só se concentravam nos empregados como também Ihes davam a impressão de que alcançar um alto nível de produtividade constituía uma das partes mais importantes de seu trabalho. Desta forma, além de concentrar-se nos empregados, o líder tem que ser um entusiasta e envolver os empregados para o atingimento dos objetivos.

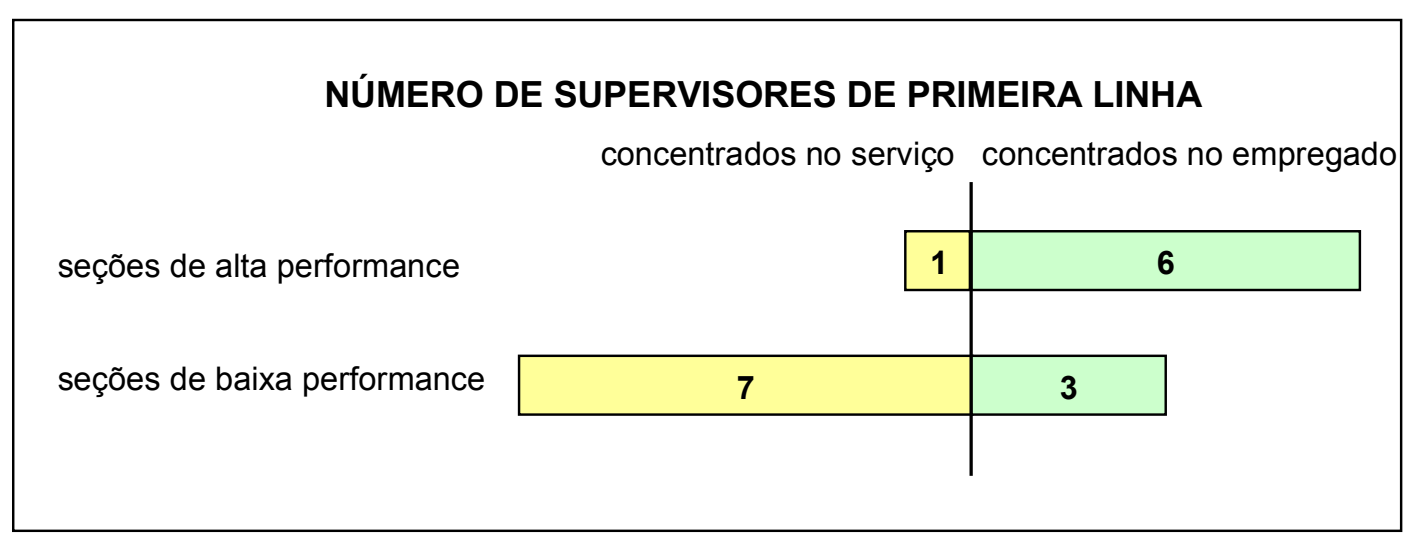

Figura 8: Supervisores concentrados: no empregado versus no serviço.

Fonte: LIKERT, R. (1979)

O estudo do Institute for Social Research aponta vantagens de desempenho também para o líder autêntico e solícito em relação ao sucesso e bem-estar de seus subordinados.

Figura 9 demonstra que os líderes de alta produtividade são cooperativos e compreensíveis, mesmo quando seus homens fazem um trabalho deficiente, pois acreditam que os empregados aprendem com seus erros.

Likert (1979, p.41) conclui esse tópico enfatizando que os dados obtidos revelam a grande importância da qualidade da liderança, e que a supervisão e o estilo gerencial adotados na organização exercem mais influência sobre sua

\footnotetext{
${ }^{8}$ KAHN, R. L. (1956). The prediction of productivity. J. Soc. Issues, 12, 41-49.
} 
eficácia do que fatores gerais, tais como: atitudes para com a empresa e interesse pelo próprio emprego.

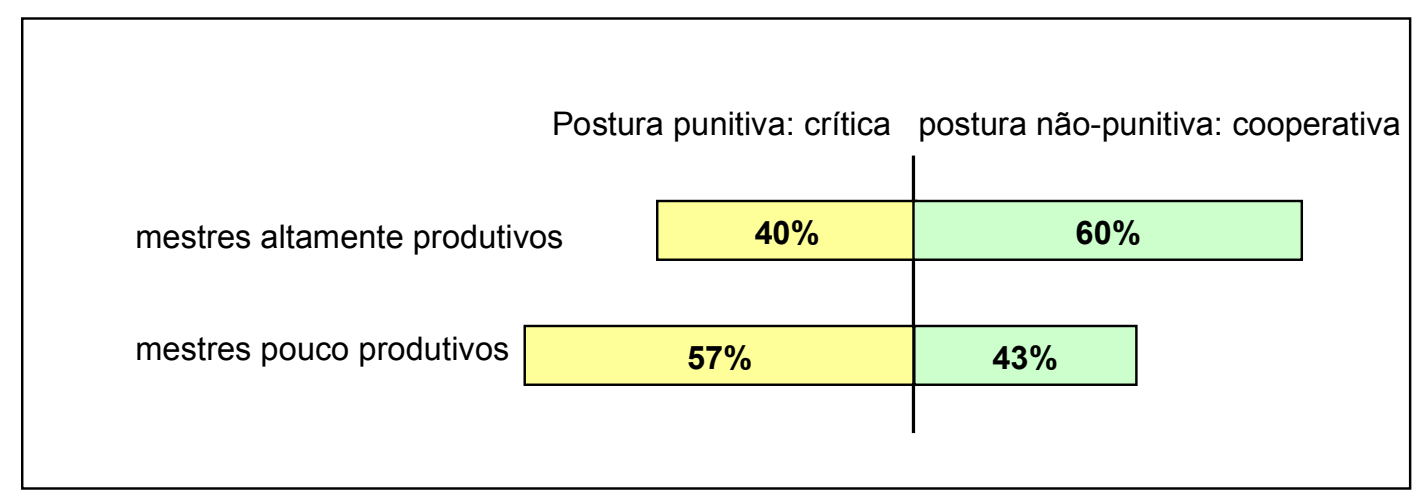

Figura 9: Mestres punitivos versus mestres não punitivos.

Fonte: LIKERT, R. (1979)

\subsubsection{ABORDAGEM SITUACIONAL DA LIDERANÇA}

Tannembaum e Schmidt $^{9}$ apud BATEMAN e SNELL (1998, p.344) descreveram como os administradores devem considerar três fatores antes de decidirem como liderar e, embora tenha sido publicados pela Harvard Business Review há quase meio século, a maioria de seus argumentos continua válida.

Os três fatores são:

a) as forças que atuam no administrador: seus valores pessoais, inclinações, sentimentos de segurança e confiança nos subordinados.

b) as forças que atuam nos subordinados: conhecimento e experiência, prontidão para assumir responsabilidades, interesse pela tarefa, entendimento e aceitação das metas da organização.

c) forças que atuam na situação: estilo de liderança valorizado pela organização, medida segundo a qual o grupo trabalha, como uma unidade eficaz, o problema em si e o tipo de informação necessária para resolvê-lo, o tempo disponível do administrador para tomar a decisão.

\footnotetext{
${ }^{9}$ TANNENBAUM, A.; SCHMIDT, W. (1958). How to choose a leadership pattern. Op. cit.
} 
De acordo com Hampton (1990), as situações em que a liderança acontece diferem-se e mudam. Há uma quantidade substancial de pesquisas que ilustram como a liderança é contingente à combinação de estilos e situações. Hampton cita Fiedler ${ }^{10}$ como principal pesquisador de liderança e responsável por evidenciar meios de se medir estilos e situações de liderança, sugerindo quais são boas combinações entre os dois.

Os estudos de Fiedler concentraram-se em três situações de liderança: a relação líder-membro, o poder da posição do líder e o grau de estruturação da tarefa, conceber uma forma de medida, por meio de questionários, primeiro para avaliar os sentimentos dos membros em relação ao líder; segundo para avaliar a capacidade do líder em promover ou rebaixar e, por fim, o nível no qual a tarefa é definida e certa, refletindo quão estruturada ela é. Os resultados dos questionários são combinados, indicando o grau de dificuldade em administrar a situação. Quanto maior o poder do líder e melhores as suas relações com os liderados, dentro de uma tarefa estruturada, mais fácil será a situação de administrar. Qualquer situação contrária será menos favorável para o líder.

Essa linha de pesquisa procura descobrir que espécie de líder alcançará um melhor desempenho de grupo em situações favoráveis, intermediárias e desfavoráveis. Apresenta a liderança orientada para a tarefa como associada com desempenho eficaz do grupo, em situações que são muito favoráveis ou muito desfavoráveis para o líder, enquanto a liderança orientada para as pessoas está associada com o desempenho eficaz do grupo, em situações de dificuldade intermediária.

\subsubsection{LIDERANÇA MOTIVACIONAL}

Maximiano (2004, p.303) difere essa abordagem das anteriores porque, enquanto as outras baseiam-se na divisão do poder de decisão entre o líder e os liderados, formando a idéia do líder autocrático versus democrático, a liderança motivacional enfatiza o tipo de recompensa oferecido pelo líder para

\footnotetext{
${ }^{10}$ FIEDLER, F. E. (1967). A theory of leadership effectiveness. New York: McGraw-Hill.
} 
a realização da tarefa e, segundo ele, existem dois estilos motivacionais: o carismático e o transacional.

A liderança carismática, inspiradora ou transformadora, é aquela em que o líder oferece como recompensa a própria realização da tarefa, suas recompensas têm conteúdo moral e seus seguidores são fiéis. Suas recompensas são compostas por satisfação e oportunidade de crescimento pessoal, associação a um líder e a uma equipe de prestígio, recompensas simbólicas e agradecimentos. Para alcançar um alto grau de comprometimento, os líderes carismáticos dispendem atenção especial para as potencialidades e necessidades de seus seguidores, encorajando-os e dando-lhes inspiração.

O líder transacional recorre aos interesses e necessidades primárias dos seguidores, prometendo recompensas materiais ou psicológicas a fim de que seus subordinados realizem as metas traçadas. Essas recompensas podem ser: promoções, aumentos salariais, autonomia e liberdade no uso do tempo, prêmios por desempenho entre outras. Esse estilo baseia-se no princípio de que o desempenho e a competência devam ser recompensados conforme algum critério.

\subsection{CARACTERÍSTICAS FUNCIONAIS E A INOVAÇÃO}

Peter Drucker ${ }^{11}$ (apud SCHULER e JACKSON, 1995, p.3), ao comentar a relação entre recompensa e estratégia de inovação, observou que ele próprio cometeu o erro de pensar ser possível inovar dentro de uma unidade operacional existente há 30 anos. Tal fato aconteceu quando prestava consultoria para a principal mudança organizacional da história americana; a reorganização da General Eletric, no começo dos anos 50. Ele advertiu os executivos e eles aceitaram o fato de que os gerentes, em geral, não só seriam responsáveis pelas operações atuais como também pelo gerenciamento do futuro. Concomitantemente, foi desenvolvido um dos primeiros planos sistemáticos de recompensas, e todo o conceito das pessoas serem

\footnotetext{
${ }^{11}$ RUTIGLIANO, A. J. (1986). Managing the New: An Interview with Peter Drucker. Management Review. p.38-41.
} 
remuneradas, baseadas em seus desempenhos no ano anterior, surgiu desse plano.

O resultado disso foi que, por dez anos, a GE perdeu completamente sua capacidade de inovar, simplesmente porque o amanhã produz custos que duram 10 anos e nenhum retorno. Então os gerentes decidiram, não apenas por preocupação com eles mesmos, mas também com seus pares, prorrogar qualquer investimento em inovação. Tão somente quando a empresa desistiu do plano de remuneração por resultados e organizou a busca pelo verdadeiramente novo (não apenas pela melhoria da aparência dos negócios existentes) é que a GE recobrou, brilhantemente, sua capacidade de inovação. Muitas empresas vão atrás do novo ou de uma modesta atualização e acabam por perceber que não têm nem um nem outro.

A estratégia de inovação é utilizada para produzir produtos ou serviços diferentes daqueles produzidos pelos concorrentes. O foco primário desta estratégia é oferecer algo novo e diferente.

Citada por SCHULER e JACKSON (1995): para encorajar tantos funcionários quantos possíveis a serem inovadores, a $3 \mathrm{M}$ criou uma doutrina informal de permitir que seus funcionários dediquem $15 \%$ de seu tempo a seus projetos pessoais. Uma abordagem menos sistemática de inovação é o estímulo para que os funcionários ofereçam sugestões para novas e melhoradas maneiras de fazer seu trabalho ou fabricar os produtos.

SCHULER e JACKSON (1995) concluem que, de uma forma global, para empresas que adotam a estratégia de inovação, o perfil do comportamento de papéis de seus funcionários inclui:
a) alto grau de comportamento criativo,
b) foco de longo prazo,
c) um relativo alto grau de cooperação e comportamento interdependente,
d) um moderado nível de preocupação com a qualidade,
e) um moderado nível de preocupação com quantidade,
f) um nível de preocupação equivalente para processos e resultados,
g) um alto grau para tomada de ação de risco,
h) alta tolerância para com a ambigüidade e imprevisibilidade. 


\subsection{GESTÃO PARA INOVAÇÃO}

De acordo com Sutton (2002), embora todo executivo saiba que a inovação exige práticas radicalmente diferentes daquelas do dia-a-dia, muitas empresas ainda sofrem quando tentam mudar a rotina. Ele salienta que grande parte do problema é o fato de os administradores recuarem ao perceberem que a inovação exige práticas estranhas e aparentemente equivocadas, que até mesmo podem provocar uma perda inicial de faturamento ou talvez nunca gerem dinheiro algum. Entretanto a longo prazo, as empresas não podem sobreviver apenas de iniciativas já experimentadas, elas precisam explorar novos procedimentos e tecnologias para satisfazer a demanda do consumidor, para ganhar vantagem sobre seus concorrentes ou até para não perder o ritmo. Sutton (2002) apresenta três princípios contra a rotina, seguidas de oito técnicas "absurdas" 12 para a mudança.

Princípios contra a rotina e que regem a exploração de novas possibilidades:

1) Acentuar a diversidade: a inovação exige aumentar a discrepância de ideais na empresa; idéias promissoras podem surgir do que antes parecia ser apenas "entulho".

2) Encarar coisas antigas de novas maneiras: ver tudo sob um novo ângulo, toda vez.

3) Romper com o passado: embora a maior parte das idéias novas seja ruim e o índice de fracasso de novos produtos e novas empresas seja bem mais alto, o que é "testado e aprovado" nem sempre resiste a uma inovação.

Oito técnicas absurdas para a mudança:

1) Provocar emoções desagradáveis nos outros; pessoas tendem a reagir com irritação, ansiedade e desaprovação ao se depararem com o desconhecido. Se todo mundo sempre gosta de suas idéias elas provavelmente não são novas.

2) Tornar-se desconfortável consigo mesmo: a inovação exige que os inventores também se contorçam porque o desconforto é um sinal de que o projeto é estranho ou arriscado, por isso deve ser inovador.

\footnotetext{
${ }^{12}$ A expressão "absurda" é do próprio autor.
} 
3) Tratar tudo como condição temporária: o trabalho rotineiro pressupõe uma condição permanente e isso não pode ser válido para o trabalho inovador. Embora romper com o passado só faça sentido quando as maneiras antigas são obsoletas, a inovação sustentável exige tratar equipes, empresas, procedimentos e linhas de produtos como temporários.

4) Ignorar os especialistas: segundo esse princípio, as pessoas que não sabem como fazer não ficam tolhidas por pressupostos existentes e, desta forma, podem ver coisas que os especialistas rejeitaram.

5) Pensar em algo ridículo e planejar sua execução: essa técnica força as pessoas a exporem e desafiarem pressupostos que atravancam o desenvolvimento de grandes idéias.

6) Fazer sessões do tipo "Vaca Sagrada": crie momentos especiais, reuniões e forças-tarefas, nas quais haja pessoas encarregadas de caçar e eliminar "vacas sagradas". Essa expressão representa maneiras ineficientes de raciocinar e agir que sobrevivem além do seu tempo de vida útil, e sobre as quais as pessoas não pensam mais ou temem mudar.

7) Incorporar pessoas lentas para aprender: as empresas precisam de pessoas que não estão dispostas ou não sejam capazes de aprender o código corporativo, entendido como "conhecimentos e crenças" de uma empresa. A inovação exige pessoas que vejam as coisas de maneira diferente e não sejam facilmente convertidas.

8) Dispersar e reagrupar equipes: as equipes podem ficar presas no passado e seus membros podem tornar-se sectários, até mesmo ignorando opiniões externas.

Leonard-Barton (1998, p.33) diz que as aptidões específicas de uma empresa aumentam sua probabilidade de explorar uma nova tecnologia e que, portanto, os gerentes devem incrementar essas aptidões e depois estimularem o desenvolvimento de planos para explorá-las. Embora as empresas tenham investido, ao longo dos anos, no incremento do saber, ainda precisam continuar a criar e modificar tais habilidades, em função de condições mutáveis. A inovação contínua é um ato de "destruição criativa", e até mesmo inovações aparentemente insignificantes comprometem a utilidade de conhecimentos já bem assimilados. Pressupondo que o futuro seja muito parecido com o presente, as empresas geralmente se preocupam em fazer as 
coisas melhores, e não diferentes do que normalmente se fazem. Por isso, as informações adquiridas passam por uma filtragem para rejeitar os conhecimentos que não sejam relevantes para as atuais aptidões estratégicas da empresa, criando, assim, atividades inibidoras do saber.

Christensen (2002, p.34) argumenta que muitas companhias de sucesso falham, não por terem uma administração ineficaz, mas justamente por que elas são bem administradas, ficando dentro padrão. Elas escutam e satisfazem as necessidades de seus melhores clientes e focam investimentos nas faixas mais lucrativas de seus mercados, sustentando seus lucros enquanto não há grandes rupturas no mercado. Quando isso acontece, seus produtos e serviços perdem mercado rapidamente por não parecerem tão bons, surgindo ainda um outro grande problema: os novos produtos não oferecem inicialmente grandes margens de lucro que possam se enquadrar ao padrão exigido pela empresa.

De acordo com Hamel e Skarzynski (2001, p.19), um problema a ser considerado é o que chamaram de "quebra do monopólio estratégico". Em muitas empresas, a hierarquia da organização domina a hierarquia das idéias e a solução sugerida é encorajar a inovação, expor idéias por toda a companhia, estimular e trazer funcionários de todos os níveis para compartilhar novas perspectivas que podem tornar-se o núcleo de novas grandes idéias.

Três caminhos são então apresentados para que executivos possam iniciar rapidamente processos que levam à inovação. O primeiro deles é justamente a quebra do monopólio estratégico, incentivando o intercâmbio entre administradores e funcionários para aquecer as conversações acerca das questões corporativas. O segundo caminho trata da busca de novas perspectivas, de uma nova visão de negócios. Por fim, a terceira possibilidade provém de inovações que despertam novas paixões. Elas surgem não somente da cabeça, mas também no coração.

Os administradores não devem amedrontar seus funcionários a engajarem-se em novos caminhos. Quando as pessoas são partes do processo e não somente um dente da engrenagem, seu empenho é bem maior.

Para a pesquisa de campo serão tratados os aspectos de gestão relacionados ao grau de cooperação entre administradores e funcionários, a influência da liderança e a eficácia de seu comportamento, os valores e formas 
de recompensas, a postura da administração diante de práticas inovadoras e sua capacidade de promover discussões acerca de novas idéias. 


\section{CAPÍTULO IV}

\section{GESTÃO DA INOVAÇÃO EM PRODUTOS E PROCESSOS}

Drucker (1999, p.30) traça o perfil do que chamou de "os cinco pecados mortais dos negócios" e cita um deles como sendo o "ato de alimentar problemas e matar de fome as oportunidades". Ele explica que grande parte das organizações designa seus melhores colaboradores internos para trabalharem na solução de problemas - velhos negócios que estão perdendo lucratividade, velhos produtos que estão sendo sufocados pela concorrência, velhas tecnologias que ficam sendo amparadas - e deixam de lado grandes oportunidades que poderiam produzir bons resultados e crescimento. Segundo Drucker o procedimento correto é o adotado pela $\mathrm{GE}^{13}$ com sua política de livrar-se de todos os negócios que não oferecem crescimento a longo prazo, e colocar seu pessoal de melhor desempenho nos negócios que oferecem oportunidades.

Hamel (2001, p.65) afirma que, na nova economia, as maiores recompensas vão para companhias que criam modelos de novos negócios idéias que trazem novas fontes de renda, baseadas em tecnologia viável e em novos hábitos dos consumidores. Um ambiente inovador pode ser criado, conscientemente, se uma empresa está disposta a abandonar velhas regras.

E a inovação não fica só no produto; uma empresa pode ser altamente inovadora e obter grande êxito nos negócios vendendo, por exemplo, sanduíches de hambúrguer, semelhantes aos de qualquer outra lanchonete,

\footnotetext{
${ }^{13}$ General Electric Company
} 
como faz a rede McDonald's. Para isso, a inovação deverá manter o foco no seu processo produtivo, de forma a atingir um diferencial que irá agregar valor aos olhos do cliente.

Exemplos como os de Henry Ford e sua linha de montagem na fábrica de Highland Park, e da General Motors com a gestão descentralizada, que fez com que as divisões da empresa tornassem-se unidades de negócio, mostraram a possibilidade de fazer-se inovação sem investir, necessariamente, grandes quantias em pesquisa e desenvolvimento de produtos.

Segundo Sabbag (2000, p.3), entre os novos trabalhadores surge uma elite, cada vez mais valorizada, e que poderá constituir-se no paradigma dessa nova era: os "trabalhadores do conhecimento". Suas qualidades são resumidas por ele como sendo compostas de: habilidade para aprender; criatividade para lidar com problemas pouco estruturados e singulares em que a experiência pouco conta; habilidade para lidar com simbolismos por meio do uso de metáforas e representações, não contando apenas com o raciocínio lógico para enfrentar a ambigüidade; vocação experimental para lidar com projetos em equipes ad hoc e sistemas de gestão adequados à transitoriedade e à experimentação; visão estratégica conjugada à habilidade operativa; interdependência e cooperação para evocar a sinergia de todos e a compreensão da interdependência entre as funções e habilidades - précondição para a cooperação; vitalidade e perfil empreendedor que exige fé, otimismo, persistência, cálculo de riscos e a busca de realizações; autonomia e responsabilidade; maturidade profissional, entendida como "mente aberta", livre de preconceitos ou convicções exageradas e desapegada das experiências passadas.

La Rovere e Medeiros (2000) apresentam um interessante debate acerca da capacidade inovadora das pequenas e médias empresas, partindo do fato de que, embora elas dependam de fatores relacionados à organização do setor e ao sistema de inovações nos quais elas se encontram, suas atividades diversificadas e estruturas flexíveis favorecem respostas rápidas a mudanças do mercado. Portanto sua capacidade de atuação em nichos de mercado que apresentam uma alta taxa de inovação, e sua menor aversão ao risco, aparecem como vantagens na geração e adoção de inovações. Diferentes tipos de programas compõem a política de inovação para PMEs, 
auxiliando sua gestão. Dentre eles: programas de capacitação tecnológica que apóiam P\&D e difusão de informações tecnológicas, programas de conscientização que colocam especialistas técnicos e consultores nas firmas para treinamento tecnológico e identificação de possibilidades de melhoria do produto ou processo, programas ponte nos quais o governo fornece educação técnica e vocacional, prescrevendo práticas baseadas em experiências de sucesso e desenvolve pólos de ciência e tecnologia.

Na região metropolitana do Rio de Janeiro, onde La Rovere e Medeiros (2000) conduziram sua pesquisa, em empresas de confecção ali instaladas, foi constatado que a partir de vínculos estáveis com empresas maiores as pequenas e médias empresas obtêm informações técnicas que são repassadas em função da necessidade de garantia de qualidade das peças. Não foi encontrada, porém, uma relação de cooperação e, quando esta existe, fica limitada aos clientes das empresas. Para obtenção de informações técnicas adicionais, as empresas agem individualmente, utilizando raramente os cursos de capacitação disponíveis.

\subsection{APRENDIZAGEM E CRIAÇÃO DE CONHECIMENTO}

Entende-se por aprendizagem e criação de conhecimento organizacional a capacidade que uma empresa tem de criar novo conhecimento, difundi-lo por toda a organização, internalizando-o em produtos, processos e serviços que transcendem a trajetória de aquisição, disseminação e memorização. Esse processo constitui-se em obtenção de inovação contínua e incremental, realizando um movimento espiralado que combina dois tipos de conhecimentos: o explícito e o tácito. O conhecimento explícito é expresso em palavras e números, sendo de comunicação fácil e podendo ser compartilhado sob a forma de dados brutos, fórmulas científicas, procedimentos codificados ou princípios universais. O conhecimento tácito engloba conclusões, insights e palpites subjetivos, todos imbricados nas ações e experiências de um indivíduo, suas emoções, valores e ideais que culminam em complexo compartilhamento e transmissão (NONAKA, 1997). 
A dependência das organizações de novos conhecimentos suscita a reflexão sobre a possibilidade de gerir, no plano organizacional, os conhecimentos sempre tratados no plano individual, enquanto processo cognitivo. Além de aprimorar a cognição individual, visando a ampliar a capacidade de aprendizagem global, buscam-se formas de compartilhamento e apropriação coletiva dos novos conhecimentos gerados. Não apenas a assimilação pelas pessoas ou grupos, mas também da incorporação desses conhecimentos na organização e em seu funcionamento: nas regras, políticas e cultura organizacional.

Segundo Sabbag (2000, p.5), há duas estratégias distintas para aprimorar conhecimentos. A primeira lida com a cognição e com o aprimoramento individual. É a estratégia tradicional que hoje denominamos de Gestão de Competências, e significa expor os profissionais a fatos, emoções e percepções, cuja compreensão é ampliada, ordenadamente, por meio da experiência, do estudo e do treinamento monitorados. A nova estratégia oferecida pela proposição da Gestão do Conhecimento significa organizar e aproveitar oportunidades de criação e compartilhamento de conhecimentos no plano organizacional. Esta estratégia não ignora o poder do relacionamento interpessoal, a sinergia enquanto "química" do sucesso de equipes e organizações, a motivação derivada da amizade e companheirismo.

Quanto à condição de transmissão, Nonaka (1997) diz que o conhecimento tácito e o explícito seguem caminhos bifurcados para depois se constituírem em um único conjunto de conhecimentos. $O$ tempo que transcorre entre a conversão do conhecimento tácito em explícito, ou vive-versa, é que determina a criação de conhecimento organizacional.

O reconhecimento da importância do conhecimento tácito faz da inovação um processo de auto-renovação, pessoal e organizacional. $O$ comprometimento das pessoas para com a empresa e a sua filosofia organizacional passam a ser fatores indispensáveis em tal processo. Essa condição impulsiona o processo de inovação, ou seja, a vontade e a determinação de recriar mundos, de acordo com uma visão específica e ideal compartilhados. A partir dessa função, a criação de conhecimento não se resume apenas em aprender com os outros ou obter conhecimentos externos. O aprendizado que vem de fontes externas à empresa necessita ser 
internalizado, isto é, modificado, melhorado e traduzido conforme a identidade e auto-imagem empresarial. Isso requer do corpo gestor a ruptura de pensar a aquisição e criação de conhecimento, de modo normativo e formal para incorporar os insights e palpites de caráter mais subjetivo, por meio de metáforas, analogias, imagens ou experiências individuais e coletivas.

\subsubsection{A ESPIRAL DO CONHECIMENTO}

A distinção entre os conhecimentos implícito e tácito é considerada como a pedra fundamental que explica a dimensão epistemológica da criação de conhecimento, cujo movimento principal está na mobilização e conversão do conhecimento tácito em fator de produção (NONAKA, 1997).

A partir da interação entre os conhecimentos explícito e tácito, os referidos autores apontam quatro modos de conversão do conhecimento, denominados: socialização (do conhecimento tácito em mais conhecimento tácito), externalização (do conhecimento tácito em conhecimento explícito), combinação (do conhecimento explícito em conhecimento explícito) e internalização (do conhecimento explícito para conhecimento tácito).

Pressupõe-se, então, que os conhecimentos tácito e explícito são entidades que se completam mutuamente, interagindo um com o outro na utilização de trocas criativas entre indivíduos, expandindo-se continuamente. A socialização é um processo que se constrói a partir do compartilhamento de experiências e da criação do conhecimento tácito, como os modelos mentais ou habilidades técnicas compartilhadas, em que a linguagem não é necessariamente utilizada: "os aprendizes trabalham com seus mestres e aprendem sua arte não através da linguagem, mas sim através da observação, imitação e prática" (NONAKA, 1997, p. 69).

Logo, a aquisição de conhecimento tácito vincula-se à experiência e ao conteúdo por esta revelado. Quando não se troca experiência, será difícil para um indivíduo projetar-se no processo de raciocínio de outro indivíduo.

A externalização relaciona-se à criação de um conhecimento perfeito à medida que o conhecimento tácito se torna explícito, na forma de metáforas, analogias, conceitos, hipóteses ou modelos. Ao conceituar uma imagem ou 
idéia, o uso da escrita permite a conversão do conhecimento tácito em explícito, ainda que não seja tão fácil esse processo, devido às expressões serem, muitas vezes, inadequadas e insuficientes.

A combinação consiste na conversão sistemática de conceitos em um sistema de conhecimento. A combinação de conjuntos diferentes de conhecimento explícito dá-se quando indivíduos trocam e combinam conhecimento por meio de documentos, reuniões, redes de comunicação computadorizadas, teleconferências, treinamentos etc. Todos esses meios reconfiguram as informações existentes por meio de acréscimo e categorização do conhecimento explícito ocasionando novos conhecimentos.

A internalização relaciona-se ao aprender-se fazendo. As experiências resultantes da socialização, externalização e combinação consubstanciam-se em recursos valiosos, quando são internalizados como conhecimento tácito dos indivíduos, expresso nos seus modelos mentais ou know-how compartilhado.

De acordo com Nonaka (1997, p.80), para a viabilização da criação do conhecimento organizacional, o conhecimento tácito adquirido e acumulado necessita ser socializado com os demais membros da organização (por meio de documentos, histórias e resgate de memória), dando início a uma nova espiral de criação do conhecimento.

A Figura 10 apresenta a espiral dos modos de conversão e seus respectivos componentes. A socialização geralmente tem início na criação de um campo de interação, facilitador da ação de compartilhar as experiências e os modelos mentais dos indivíduos. No modo de externalização ocorre o diálogo e a reflexão do grupo de trabalho, ricos de significado e que empregam o uso de metáfora e analogia na articulação do conhecimento tácito. A combinação é realizada pela relação do conhecimento recém criado e do conhecimento preexistente em uma rede, materializando-se em novo produto, serviço ou modelo de gestão. E, por último, a internalização relaciona-se com o aprender fazendo.

Esse modelo espiralado da criação de conhecimento servirá de base para a compreensão do processo de aprendizagem, com vistas a uma possível relação entre o estilo de gestão presente e a capacidade de geração de conhecimento que leva ao desenvolvimento de produtos e processos que propiciem vantagem competitiva à empresa. 


\section{Espiral do Conhecimento}

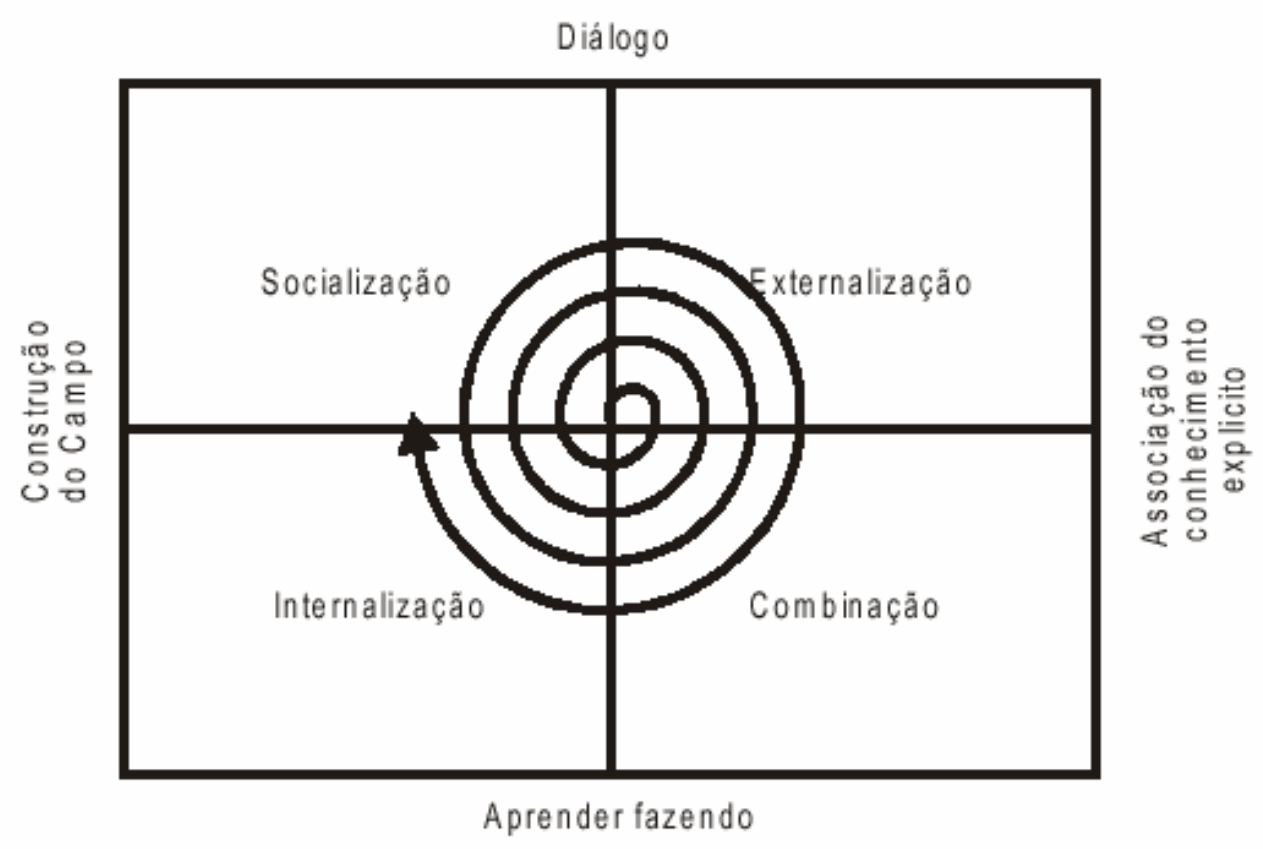

Figura 10: A espiral do conhecimento.

Fonte: NONAKA, I. (1997).

\subsection{A NOVIDADE E A INOVAÇÃO}

A palavra inovação remete à novidade, à qualidade de novo ou à coisa nova $^{14}$ e, por meio de uma análise criteriosa da relação valor/preço, definida por Porter (1998), pode-se inferir que a inovação é assim caracterizada quando o consumidor ou usuário de um produto ou serviço reconhece e atribui um valor adicional ao novo produto ou serviço, considerando diferenciais perceptíveis a ele. Cabe observar que inovação é também ganhar dinheiro por meio de alguma coisa, ou arranjo, que antes não era usado, mas se não cria valor, não é inovação, é apenas novidade, e novidade é irrelevante em negócios.

\footnotetext{
${ }^{14}$ Definição constante em FERREIRA, A. Dicionário da Língua Portuguêsa. Rio de janeiro: Nova
} 
Casarotto (2002, p.126) diz que "a inovação pode ser definida como a transformação de uma idéia tecnicamente viável (invenção) em produtos ou processos até sua utilização com sucesso comercial".

Cabe aqui apresentar, por meio da Figura 11, o gráfico de Hayes e Wheelwright $^{15}$ (1994 apud Casarotto, 2002, p.127) com as curvas típicas das taxas de inovação do produto e do processo versus a maturidade do produto, combinado com exemplos apresentados por Casarotto (2002, p.128). As retas tracejadas "A" e "B" são exemplos de duas estratégias de inovação, com ênfase respectiva em produto e processo. A reta "A" demonstra uma ênfase na inovação de produto, na opção de comercialização de produtos diferenciados e mais caros. A reta "B" indica uma opção estratégica de inovação em processos, possibilitando a oferta de produtos mais baratos.

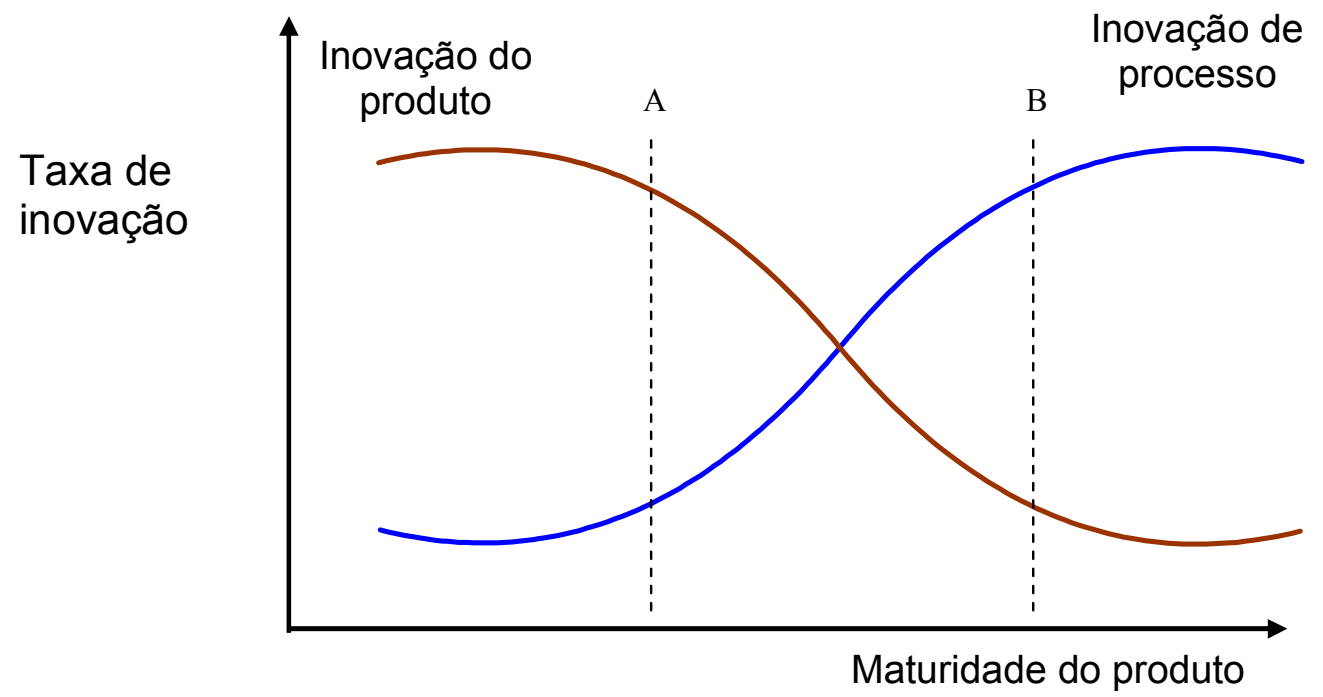

Figura 11: Curvas de inovação. Adaptado de Casarotto (2002, p.127).

\subsection{A DINÂMICA DA INOVAÇÃO}

Conforme descrito por Wheelwright e Clark (1992), a maioria dos desenvolvimentos de novos processos e produtos é complexa e envolve

\footnotetext{
${ }^{15}$ HAYES, R. H.; WHEELWRIGHT, S. C. (1984). Restoring our competitive edge-competing
} through manufacturing. New York: John Wiley. 
centenas de decisões, pessoas diferentes e objetivos múltiplos com interesses competitivos, mas os benefícios antecipados do desenvolvimento de novos produtos sempre desafiam a descrição. Neste contexto, os principais benefícios de um processo de desenvolvimento de esforços podem ser compreendidos em três principais tipos:

1) Posição de mercado: um novo produto pode fixar padrões industriais, que se tornam uma barreira para os competidores, ou mesmo abrir novos mercados antes não explorados;

2) Utilização de recursos: por meio, tanto da capitalização de investimentos anteriores de P\&D, quanto da melhora no retorno de ativos existentes (como força de vendas, produção etc.); aplicando novas tecnologias em ambos: produtos e processos, e eliminando os recursos que se encontram ociosos;

3) Renovação e transformação da organização: por meio da imagem e crescimento associados ao desenvolvimento do produto ou processo, reforçando de forma substancial o comprometimento, inovação e criatividade entre todos os membros da organização.

De acordo com Utterback (1996), não havendo restrições impostas por normas técnicas universais, ou por expectativas uniformes em relação ao produto no mercado, os participantes pioneiros da nova tecnologia desfrutam de uma ampla liberdade para experimentar novas formas e materiais. Este pioneirismo prevaleceu nos primórdios da indústria automobilística, quando um grande número de veículos com projetos específicos surgiu em centenas de oficinas nos Estados Unidos e Europa. Com o mercado formando suas expectativas para o produto em termos de características, formato e capacidade, as bases sobre as quais a inovação do produto pode ocorrer tornam-se menores e o foco se concentra nas inovações incrementais das características existentes.

Basicamente, a organização de uma empresa criada em torno de uma inovação passa por uma transformação que a maioria das organizações empreendedoras experimenta, na medida em que se tornam mais bemsucedidas e mudam o seu enfoque do produto inovador para a produção de produtos padronizados. Durante os períodos de grande incerteza de mercado e de ordem técnica, uma unidade produtiva precisa estar concentrada para fazer 
progressos. Para que um grupo seja bem-sucedido em um ambiente incerto, os indivíduos que constituem a organização precisam agir em conjunto. Esta estrutura é chamada orgânica e enfatiza o ajuste freqüente, a redefinição de tarefas, a hierarquia reduzida e um alto grau de comunicação lateral. Uma empresa orgânica é adequada para ambientes incertos, em função do seu maior potencial para coleta e processamento de informações para tomada de decisões. O poder relativo das pessoas nas empresas orgânicas está relacionado com o papel empreendedor que assumem e a capacidade inovadora deste tipo de organização é alta.

À medida que a empresa perde seu caráter orgânico, o poder relativo das pessoas começa a se afastar daquelas com habilidades empreendedoras, deslocando-se em direção àquelas com aptidões gerenciais. $\mathrm{O}$ crescimento $\mathrm{e}$ estruturação da organização exigem um conjunto diferente de habilidades.

Quando o ambiente empresarial torna-se mais conhecido e as operações se tornam rotina, considera-se necessário implementar uma coordenação mais rígida para minimizar a ineficiência e os custos operacionais. Cria-se, então, um tipo de estrutura chamada mecanística, em que a capacidade de inovação tende a ser baixa pois, torna-se, nesta estrutura, uma ameaça e um aborrecimento devido ao alto grau de integração dos processos e um alto grau de interdependência entre os sub-processos. As interrupções e os custos associados a grandes mudanças tornam-se uma preocupação fundamental.

\subsection{A ESTRUTURA DE DESENVOLVIMENTO DE PRODUTOS E PROCESSOS}

Produtos novos chegam ao mercado por meio de procedimentos que primeiro transformam idéias e conceitos em protótipos, em projetos que são testados e finalmente produzidos por empresas.

Para atingir o sucesso no desenvolvimento de projetos é necessária uma estrutura coerente e um bom entendimento dos processos envolvidos, porém, de acordo com Wheelwright e Clark (1992, p.135), em algumas empresas os projetos não possuem objetivos claros; em outras, os procedimentos e regras 
são excessivos ou não são bem entendidos. Isso requer atenção e esforços por parte dos administradores para que não haja confusão e atrasos que podem sufocar os projetos.

Wheelwright e Clark (1992, p.161) apresentam cinco princípios básicos que se aplicam aos processos de desenvolvimento:

1) Foco no cliente: deve-se conhecer e entender as exigências do cliente, traduzindo suas necessidades em condições que possam ser desenvolvidas no projeto.

2) Disciplina: embora regras excessivas e procedimentos burocráticos possam reprimir a criatividade, disciplina é essencial para alcançar, com rigor, eficácia e consistência, o desenvolvimento de um projeto.

3) Coerência nos detalhes: a relação entre líderes e responsáveis deve ser integrativa, e não de forma a segregar a equipe.

4) Ajuste com a missão: estabelecer um padrão entre o mercado competitivo e o padrão de desenvolvimento é essencial devido à complexidade do ambiente.

5) Compartilhamento do padrão: deve haver coerência na estrutura de desenvolvimento para que haja a criação de modelos de como transformar idéias em produtos e processos comerciais. Se articulados dentro da empresa, esses modelos tornam-se um idioma compartilhado e uma estrutura para desenvolvimento. Esta parte é destacada como crucial em um processo de desenvolvimento efetivo dentro da empresa.

\subsection{O MIX ESTRATÉGICO E A INOVAÇÃO}

Porter $^{16}$ (1986 apud CASAROTO FILHO, 2002) identifica três estratégicas quanto à competitividade: a liderança em custos, a liderança pela diferenciação e a liderança pelo foco de mercado. A primeira é voltada para a produção em massa, com ênfase no processo e baixos investimentos em pesquisa de produto. A estratégia de diferenciação, que possui sua atenção voltada para o produto tendo como objetivo torná-lo único no mercado,

\footnotetext{
${ }^{16}$ PORTER, M. E. (1986). Estratégia Competitiva. Rio de Janeiro: Campus.
} 
demanda investimentos em pesquisa e necessita de grande flexibilidade na estrutura da empresa. A terceira visa atingir um segmento de mercado, o que caracteriza uma especialização, não em relação ao produto, mas, em relação ao mercado.

\subsubsection{ESTRATÉGIAS QUANTO À COMPETITIVIDADE}

Ainda segundo Porter (1998), o meio-termo entre custo e diferenciação não é indicado e o que vale é a relação valor/preço do produto, devendo ser maior do que 1, ou seja, o consumidor deve atribuir um valor ao produto, maior do que o seu preço. Neste cenário, completa o autor, encaixam-se as pequenas empresas, em contraponto às grandes empresas que fazem produtos mais baratos do que realmente valem. Ambos os extremos da Figura 12, a seguir, ilustram essa condição, porém demandam algum tipo de ação inovadora para o alcance de seus objetivos, seja ela no produto ou no processo, pois, sugerem melhoria contínua.

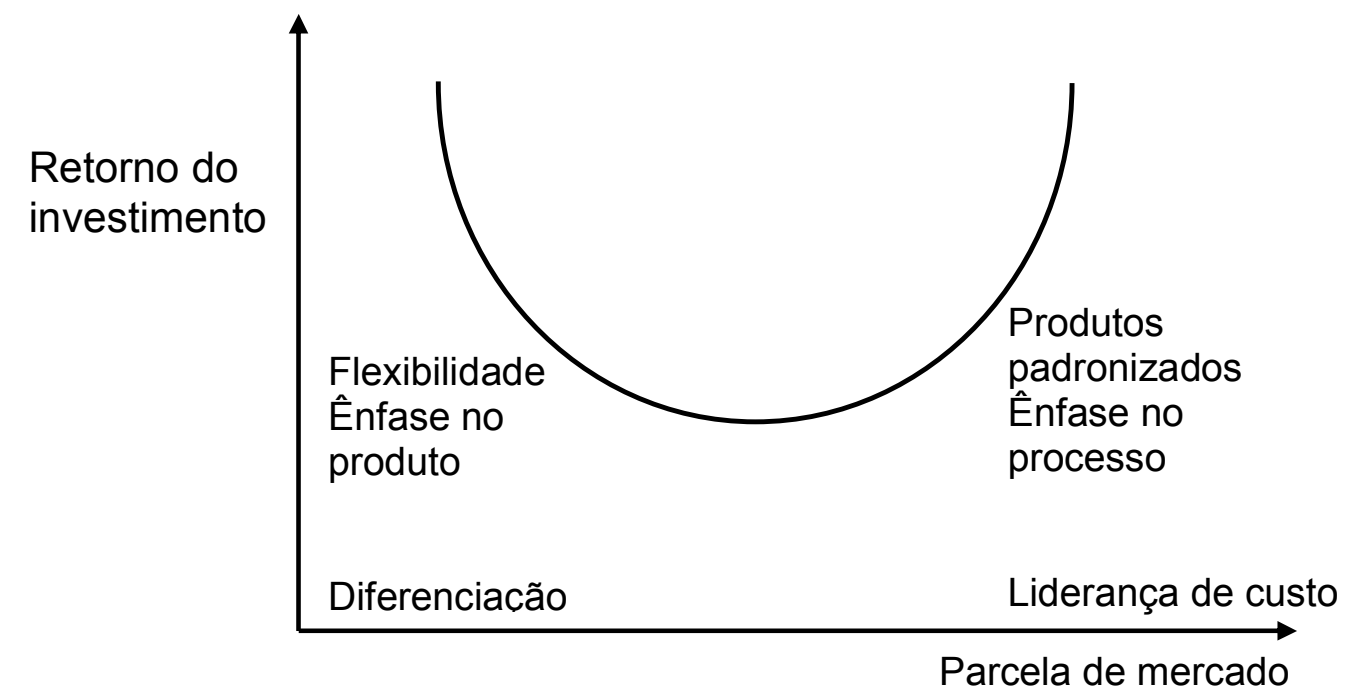

Figura 12: Retorno do investimento versus parcela de mercado.

Fonte: Casarotto (2002).

A pequena empresa, mesmo com o envolvimento nos processos de terceirização, parcerização ou outra forma qualquer de repasse da produção 
por uma grande empresa, só conseguirá retorno de seus investimentos, conforme o modelo proposto, se todos atingirem um dos extremos.

Sob a perspectiva das redes flexíveis de pequenas empresas, contrapondo-se na curva original de Porter, as pequenas empresas são recolocadas por Casarotto (2002, p.45), conforme a Figura 13.

Sendo assim, uma pequena empresa poderá competir: pela diferenciação do produto enquanto associada ou não a um nicho de mercado; pela liderança em custo, sendo fornecedora em uma rede topdown; ou pela flexibilidade/custo em uma rede de empresas flexíveis. Para uma pequena empresa, desenvolvimento de produto pode significar a criação de uma nova embalagem para o produto de uma empresa maior ou uma mudança significativa num determinado processo produtivo para atender rapidamente uma empresa dominante em algum segmento do mercado.

Portanto, com base nos trabalhos de Porter (1986) e Casarotto (2002), a pequena empresa deve incorporar, em seu processo estratégico, a inovação como um ponto essencial para o sucesso de seus negócios.

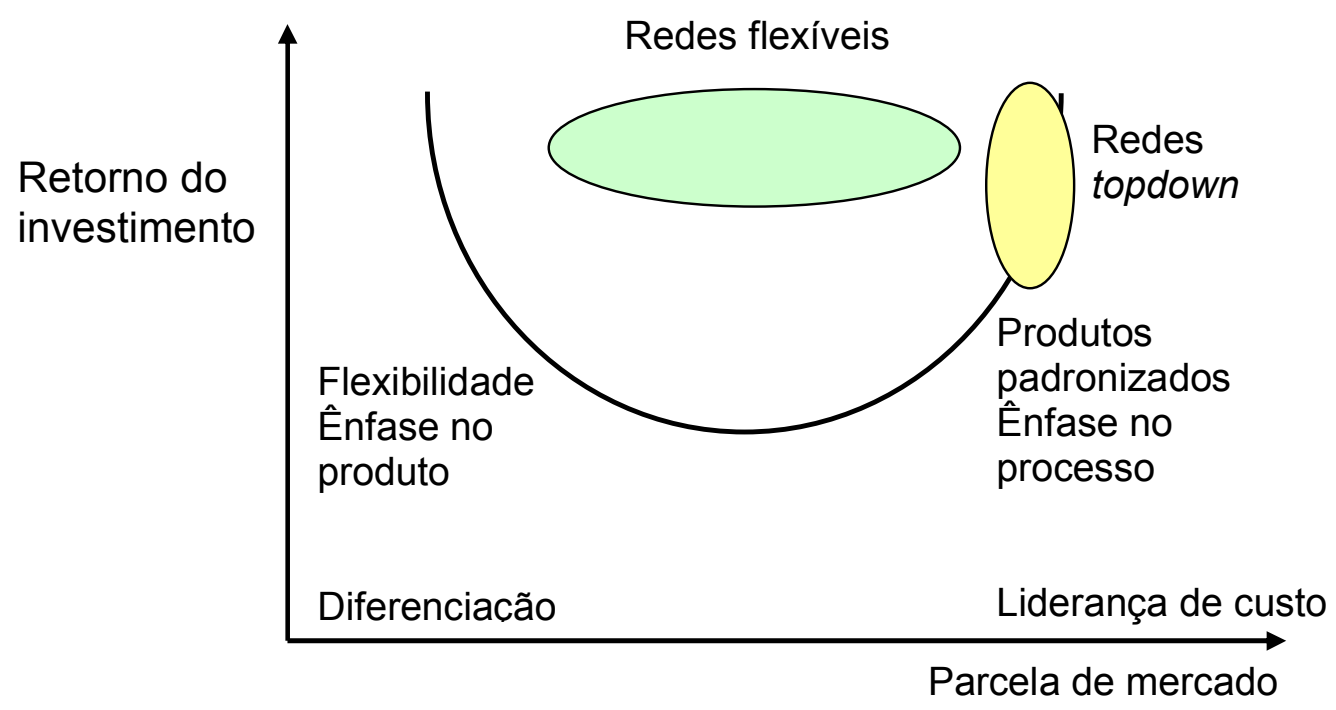

Figura 13: Curva "U" e estratégias competitivas ampliadas.

Fonte: Casarotto (2002). 


\subsubsection{ESTRATÉGIAS QUANTO AO PRODUTO E AO MERCADO}

Ansoff (1990) apresenta a matriz produto/mercado composta por quatro possíveis estratégias, conforme demonstrado na Figura 14.

Pela figura é possível identificar que a estratégia de penetração dá-se com os mesmos produtos para os mesmos mercados, o que sugere melhorias de produtividade por meio de novos processos. Para o mercado atual, uma outra estratégia é o desenvolvimento de novos produtos, novos processos ou ambos.

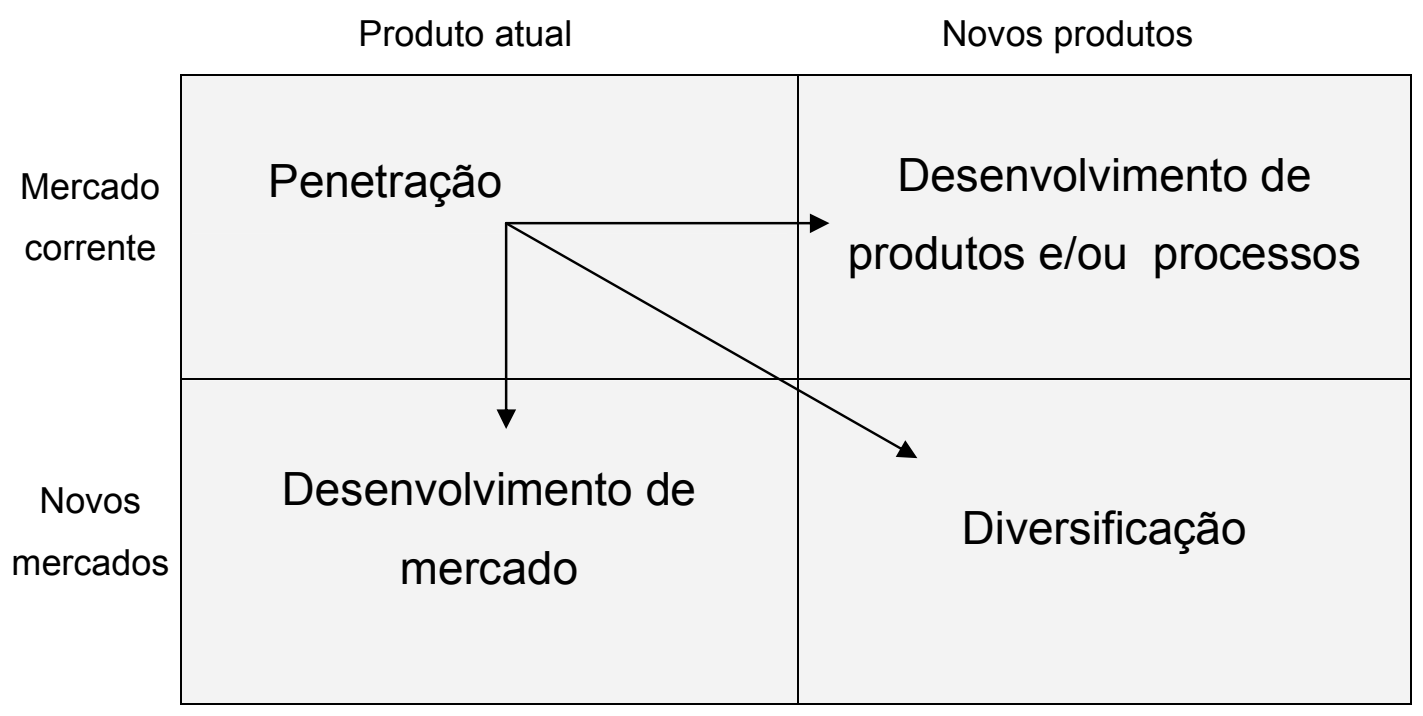

Figura 14: Matriz produto/mercado

Fonte: Ansoff (1990).

Novos produtos para novos mercados implicam diversificação que, de acordo com Casarotto (2002, p.48), pode-se dar de três maneiras:

1) Diversificação lateral: novos produtos em linhas de produção ou processos paralelos;

2) Integração a jusante: novos produtos tendo como matéria-prima seus atuais produtos;

3) Integração a montante: novos produtos como insumos para seus atuais produtos, podendo também ser destinados ao mercado. 


\subsubsection{ESTRATÉGIAS QUANTO A UTILIZAÇÃO DOS MEIOS}

Citada por vários autores como: Maximiano (2004 p.178) Bateman e Snell (1998 p.131) e Casarotto (2002 p.49), em administração, estratégia, produção, análise de projetos e matérias relacionadas, a Matriz BCG do Boston Consulting Group aparece como uma ferramenta consolidada para avaliação de negócios nas organizações modernas inseridas em mercados complexos.

Nela, cada produto ou negócio da empresa é plotado na matriz com base na taxa de crescimento do respectivo mercado e da relativa força de sua posição competitiva nesse mercado. O produto ou negócio é representado por um círculo de tamanho equivalente à sua contribuição para a receita total da empresa:

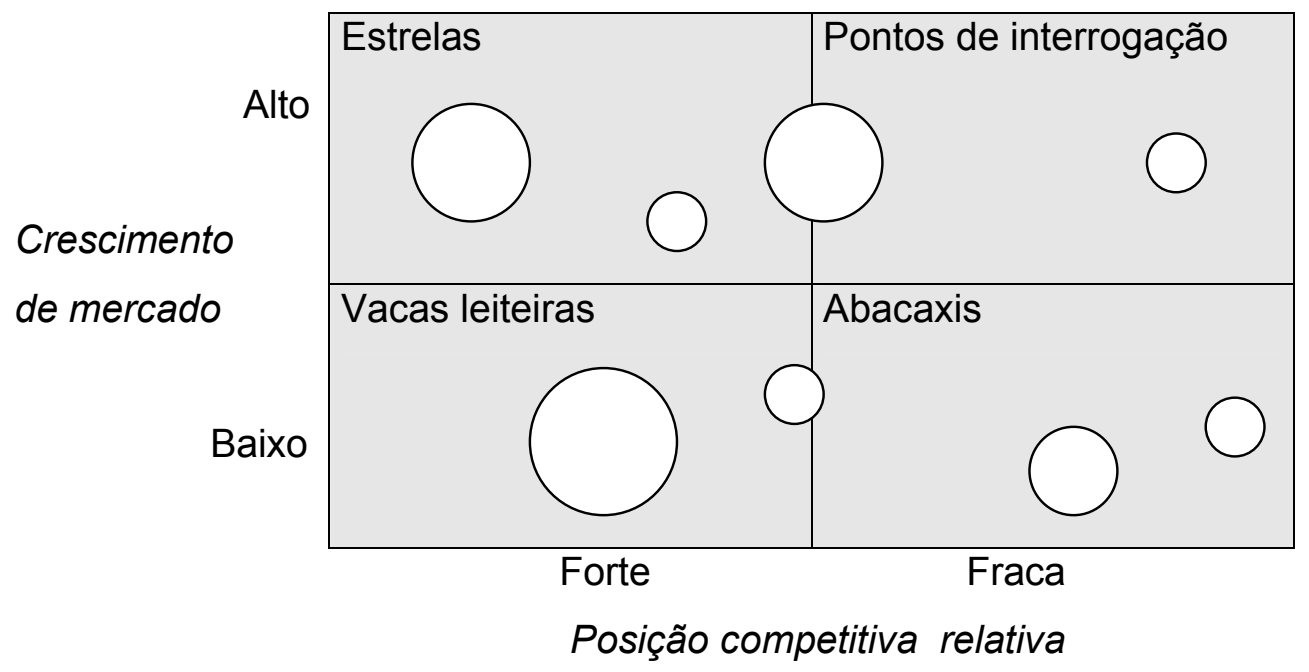

Figura 15: A Matriz BCG.

Fonte: Casarotto (2002 p.49).

Produtos "estrela" possuem alto crescimento de mercado e ainda necessitam de investimentos para manutenção de sua forte posição competitiva, ao contrário dos produtos classificados como "vaca leiteira", possuidores de uma forte posição competitiva, mas que estão inseridos num mercado de baixo crescimento.

O ciclo normal é que produtos classificados como pontos de interrogação, com alto crescimento de mercado e baixa fatia relativa, passem para estrela por meio de investimentos na melhoria dos processos, levando a 
liderança por custos, ou então, na impossibilidade de endividamento, deve-se buscar uma estratégia de diferenciação.

Vianna ${ }^{17}$ (1992 apud CASAROTTO, 2002) incorporou uma inovação ao modelo inserindo a variável "intencionalidade", que inclui fatores como: ambição e paixão pelo negócio, persistência e disposição ao risco. A vontade de correr e enfrentar riscos, acreditar no negócio e ter gosto pelo que se faz. Tais características estão referenciadas no capítulo III, como pertinentes ao perfil empreendedor.

\subsection{A INOVAÇÃO NA PEQUENA EMPRESA}

Longenecker, Moore e Petty (1997, p.35) questionam a importância da grande empresa para atingir as inovações verdadeiramente significativas e mostram alguns exemplos de novos produtos que foram criados por pequenas empresas no século XX:

Tabela 2: Inovações de pequenas empresas no século XX.

\begin{tabular}{|c|c|}
\hline Fotocópias & Transmissão automática \\
\hline Insulina & Motor a jato \\
\hline Aspirador de pó & Helicópitero \\
\hline Penicilina & \begin{tabular}{c} 
Direção eletrônica \\
\hline Colhedora de algodão
\end{tabular} \\
\hline Zíper & Filme colorido \\
\hline Caneta esferográfica
\end{tabular}

Fonte: Longenecker, Moore e Petty (1997, p.35).

\footnotetext{
${ }^{17}$ VIANNA, M. A. (1992). Avaliação prospectiva de protfólio, base para o desenvolvimento
} sustentado das empresas. São Paulo: Sociedade Brasileira de Planejamento Empresarial. 
Os autores ressaltam a probabilidade de que algumas idéias geradas pelas grandes empresas sejam deixadas de lado por não haver relacionamento com produtos existentes ou devido a sua natureza incomum. Essa preocupação com produtos existentes pode fazer com que as pessoas não enxerguem o valor de uma idéia nova.

Nota-se que as pequenas empresas são freqüentemente engajadas em P\&D informal (não necessariamente contabilizado); em áreas relacionadas com a comercialização de tecnologias existentes, criação ou re-engenharia de serviços. Geralmente, elas desenvolvem inovações incrementais e são responsáveis por grande parte do processo de adaptação de novos produtos, ou serviços mais adequados às demandas dos consumidores.

Constata-se também a tendência à inserção das pequenas empresas em redes e parcerias com outras empresas e instituições, com o objetivo de tirar proveito de fluxos de informações que favorecem o esforço inovador e a capacitação desses parceiros. Vários estudos foram evidenciados por Perussi Filho (2001) e mostram que a problemática tem a ver com questões importantes como uma política de empreendedorismo e de apoio à inovação, capacitação e treinamento em gestão empresarial, capacidade organizacional e tecnológica, processo de aprendizado, acesso a conhecimentos, interações e parcerias entre empresas e outras instituições, identificação de oportunidades tecnológicas e mercadológicas, relação entre criação de empresas e difusão de novas tecnologias.

A sobrevivência das empresas exige, cada vez mais, que elas aprendam a aprender, tornando-se empresas inteligentes, ágeis e adaptativas e, neste ponto, a pequena empresa apresenta a vantagem de poder reagir rapidamente às mudanças na realidade empresarial (TERENCE, 2002, p.61).

Pode-se notar que a literatura sobre pequenas e médias empresas debate o papel inovador destas empresas, trazendo muitas características que favorecem a sua atividade inovadora. De acordo com Terence (2002), as pequenas empresas possuem qualidades que podem oferecer contribuições excepcionais na medida em que introduzem inovações. A atividade inovadora tende a diminuir com o nível de concentração de um setor e, dado o grande número de pequenas empresas, estas levam o mercado a uma menor 
concentração. Como observado por Rothwell e Dodgson ${ }^{18}$ (1993 apud LA ROVERE e MEDEIROS, 2000, p.2), tanto as pequenas, médias e as grandes empresas têm vantagens para gerar e adotar inovações. Enquanto as grandes empresas têm vantagens materiais para gerar e adotar inovações, devido à sua maior capacidade de P\&D, as pequenas e médias empresas têm vantagens comportamentais relacionadas à sua maior flexibilidade e capacidade de adaptação a mudanças no mercado.

Entretanto, as pequenas e médias empresas não têm consciência dos possíveis ganhos de competitividade trazidos pelas inovações. A maioria das PMEs introduz inovações apenas quando elas percebem claramente as oportunidades de negócio ligadas à inovação (GAGNON e TOULOUSE ${ }^{19}, 1996$ apud LA ROVERE e MEDEIROS, 2000) . Ou, então, porque estão sob pressão de clientes e/ou fornecedores. Isto ocorre devido às especificidades do processo de aprendizado tecnológico das PMEs, em que a busca e seleção de informações é afetada por limitações de tempo e de recursos humanos. Por causa disso, nem sempre estas empresas adotam inovações, o que limita a obtenção de ganhos de competitividade.

Nas pesquisas empreendidas por Filion (1999), foi observado ainda que, embora alguns dos empreendedores entrevistados tivessem uma grande quantidade de idéias brilhantes, eles não prosperaram devido à falta de foco e concentração.

Conforme estudo apresentado por La Rovere e Medeiros (2000), e desenvolvido entre pequenas e médias empresas de confecções situadas na região metropolitana do Rio de Janeiro e adjacências, foi verificado que, a partir do estabelecimento de vínculos estáveis com empresas maiores, as PMEs garantem a demanda de seus produtos devido à força da marca da empresa maior, e obtêm informações técnicas que são repassadas a elas, em função da necessidade de garantia da qualidade das peças. As relações de cooperação, quando existem, limitam-se aos clientes das empresas. Apesar dos dirigentes das empresas entrevistadas conhecerem-se mutuamente, eles não trocam informações e as PMEs, em geral, não tomam a iniciativa de desenvolvimento

\footnotetext{
${ }^{18}$ ROTHWELL, R.; DODGSON, M. (1993). Technology-based SMEs: their Role in Industrial and Economic Change. Buckinghamshire, UK: Inderscience Enterprises.

19 GAGNON, Y. C.; TOULOUSE, J.M. (1996). The Behavior of Business Managers when Adopting New Technologies. Technological Forecasting and Social Change, 52.
} 
de novos produtos, limitando-se simplesmente a ouvir os clientes e atendê-los em suas especificações. Apenas uma empresa foi além de inovações incrementais nos produtos, tendo desenvolvido novos produtos a partir da identificação de nichos de mercado específicos. As entrevistas evidenciaram que as pequenas e médias empresas daquela região agem segundo planejamento e necessidades de curto prazo, seguindo uma estratégia de sobrevivência. Poucas empresas incluem a atividade inovadora no planejamento de suas atividades. Foi observado também que a maior parte dos entrevistados ainda tem posturas arcaicas no que se refere às relações de trabalho, considerando os empregados de forma paternalista e demonstrando pouco interesse em interações com eles o que poderia estimular a geração de conhecimento.

Com base nos tópicos precedentes e no perfil do empreendedor ressaltado no parágrafo acima, o presente trabalho começa a formar elementos que reforçam a necessidade de um estudo mais aprofundado em relação às estratégias de inovação para manutenção e conquista de vantagens competitivas na pequena empresa bem como o alinhamento dessas estratégias ao estilo de gestão do empreendedor.

Analisando três itens precedentes, que irão auxiliar na análise do mix estratégico da empresa: competitividade, produto versus mercado e a estratégia de utilização dos meios, pode-se encontrar vasta referência à necessidade de inovar e a conseqüente capacidade de desenvolvimento de novos produtos e processos.

A criação de novas empresas é um mecanismo fundamental para o desenvolvimento econômico de um país ou região. O surgimento de novas empresas, ao invés do crescimento das grandes empresas, propicia uma melhor distribuição da renda e o surgimento de novas oportunidades para o aproveitamento de recursos naturais e humanos.

Diante do que foi exposto, deve-se enfatizar a necessidade de desenvolvimento de novas técnicas administrativas, adequadas às particularidades das pequenas empresas, considerando as dificuldades enfrentadas na obtenção de capital, a baixa disseminação do conhecimento e um menor controle sobre o ambiente externo bem como os pontos favoráveis: uma estrutura organizacional simples e de menor custo, maior centralização 
permitindo maior agilidade ao processo decisório e facilidade de comunicação como vantagem competitiva.

Embora os processos que levam à inovação, e que foram encontrados na literatura pesquisada, compreendam um amplo conjunto de atividades que antecedem até mesmo a concepção da idéia do produto ou processo, e que só termina após seu lançamento, o presente trabalho irá adotar como parâmetro para a pesquisa de campo a teoria apresentada na seção 4.4 tal teoria diz respeito à estrutura favorável para desenvolvimento de projetos, por estar essa fase inicial mais alinhada com os objetivos deste trabalho. Inovação será entendida como o resultado positivo para a empresa com o público externo, obtido por meio de melhorias ou lançamento de novos produtos ou processos, que venham sustentar vantagens na competição de mercado. 


\section{CAPÍTULO $v$}

\section{O TRABALHO DE CAMPO}

Para o alcance dos objetivos da pesquisa foi realizado um estudo multicasos, adotando-se a metodologia referenciada na seção 5.3. As empresas selecionadas para a pesquisa estão descritas no presente capítulo.

\subsection{APRESENTAÇÃO DO SETOR DE PESQUISA}

Situada no centro do interior de São Paulo, estado brasileiro de maior industrialização e um dos maiores mercados da América Latina, São Carlos, além de firmar-se nas duas últimas décadas como um tecnopolo, também é um importante pólo industrial, constituindo junto com outras cidades tais como Sorocaba e Ribeirão Preto, em uma das regiões mais ricas e industrializadas do interior paulista. A reunião de uma série de fatores: um percurso histórico de investimentos em educação e ciências que desencadeou um processo cumulativo de formação de pesquisadores e desenvolvimento de pesquisa de alto nível, a existência de cursos profissionalizantes, de uma base industrial forte e diversificada, e da mobilização e envolvimento de algumas instituições locais terminaram por consolidar na cidade um ambiente propício ao surgimento do tecnopolo (BAPTISTA, 2000).

O movimento de criação de empresas de base tecnológica já pode ser observado no contexto de São Carlos, a partir da década de 1960, mas 
intensifica-se a partir de 1980. Em 1984 foi instituída uma fundação, a Fundação Parque de Alta Tecnologia de São Carlos, com a missão de ser a gestora desse arranjo organizacional. Atualmente, São Carlos abriga dezenas de empresas de base tecnológica que atuam em áreas consideradas de "tecnologia de ponta", tais como: microeletrônica, informática, robótica, mecânica de precisão, química fina, entre outras. Além das empresas de base tecnológica e da Fundação, uma série de outros órgãos e instituições locais têm exercido importante papel na formação e desenvolvimento desse tecnopolo, dentre as quais destacam-se: a Universidade de São Paulo - USP, a Universidade Federal de São Carlos - UFSCar, a Prefeitura Municipal, o SEBRAE, SENAI, CIESP/FIESP, entre outras (BAPTISTA, 2000).

O trabalho de campo foi realizado com uma amostra de empresas industriais localizadas no pólo tecnológico da cidade de São Carlos, de onde foi selecionada uma amostra de três empresas de sucesso.

\subsection{CRITÉRIOS DE CLASSIFICAÇÃO DA PEQUENA EMPRESA}

De acordo com o Art. $1^{\circ}$, da Lei 9.841, de 05/10/1999, nos termos dos arts. 170 e 179 da Constituição Federal, é assegurado às microempresas e às empresas de pequeno porte tratamento jurídico diferenciado e simplificado nos campos administrativo, tributário, previdenciário, trabalhista, creditício e de desenvolvimento empresarial, em conformidade com o que dispõe aquela Lei e a Lei $n^{\circ}$ 9.317, de 5 de dezembro de 1996, e alterações posteriores ${ }^{20}$.

O tratamento jurídico simplificado e favorecido, estabelecido nesta Lei, visa facilitar a constituição e o funcionamento da microempresa e da empresa de pequeno porte, de modo a assegurar o fortalecimento de sua participação no processo de desenvolvimento econômico e social.

Segundo a referida Lei, o conceito formal de micro e pequena empresa

${ }^{20}$ Informações obtidas no site do SEBRAE - Disponível em http://www.sebrae.com.br/br/ued/index.htm. acesso em 27/03/2004. 
foi estabelecido considerando-se:

I. Microempresa, a pessoa jurídica e a firma mercantil individual que tiver receita bruta anual igual ou inferior a $R \$ 244.000,00$ (duzentos e quarenta e quatro mil reais);

II. Empresa de pequeno porte, a pessoa jurídica e a firma mercantil individual que, não enquadrada como microempresa, tiver receita bruta anual superior a $R \$ 244.000,00$ (duzentos e quarenta e quatro mil reais) e igual ou inferior a $R \$ 1.200 .000,00$ (um milhão e duzentos mil reais).

A tabela 3, abaixo, apresenta os critérios de classificação das micro e pequenas empresas brasileiras sobre a óptica do SEBRAE:

Tabela 3: Critérios de classificação das MPE

\section{Classificação de empresas por número de empregados}

\begin{tabular}{|c|c|c|}
\hline & Na indústria & No comércio e serviço \\
\hline ME (Microempresa) & Até 19 empregados & Até 09 empregados \\
\hline PE (Pequena empresa) & De 20 a 99 empregados & De 10 a 49 empregados \\
\hline MDE (Média empresa) & De 100 a 499 empregados & De 50 a 99 empregados \\
\hline GE (Grande empresa) & Acima de 499 empregados & Acima de 99 empregados \\
\hline
\end{tabular}

Fonte: SEBRAE (2004).

Neste trabalho será adotada a classificação do SEBRAE, de acordo com a Tabela 3 apresentada. 


\subsection{METODOLOGIA}

\subsubsection{CARACTERIZAÇÃO DA PESQUISA}

Devido às suas características, a pesquisa pode ser classificada (VERGARA, 2000):

- Quanto aos fins, como uma pesquisa exploratória e descritiva.

- Quanto aos meios de investigação, como de campo.

- Quanto ao tratamento dos dados, como qualitativa.

A pesquisa caracteriza-se como exploratória porque visa proporcionar maior familiaridade com o problema, com o intuito de torná-lo explícito, sendo realizada em área em que há pouco conhecimento acumulado e sistematizado. (VERGARA, 2000, p.47).

Em relação aos meios de investigação, classifica-se como pesquisa de campo por trazer uma investigação empírica realizada no local onde ocorre o fenômeno ou onde são dispostos os elementos para explicá-lo.

Foi aplicada uma forma bastante comum de coleta de dados que é a entrevista, realizada por meio de formulários que o pesquisador preencheu de acordo com as respostas do entrevistado.

Além de caracterizar-se como pesquisa de campo, também carrega características do estudo multicasos, pois, propõe-se a analisar mais de uma empresa, sem a necessidade de perseguir objetivos de natureza comparativa. (VERGARA, 2000). O estudo multicasos permitiu que a análise dos dados não ficasse restrita às particularidades de uma única empresa.

A escolha das três empresas pesquisadas foi intencional, estando elas instaladas no pólo tecnológico de São Carlos.

Para que os resultados obtidos neste tipo de delineamento sejam significativos, recomenda-se o estudo de certa variedade de casos. Estes, em geral, não são selecionados mediante critérios estatísticos. 


\subsubsection{QUESTÕES DA PESQUISA}

De acordo com o objetivo proposto, as questões da pesquisa são as seguintes:

1) Quais são os estilos de gestão mais evidentes nas pequenas empresas consideradas inovadoras?

2) Como o gestor contribui para a criação e o desenvolvimento de projetos na empresa?

3) De que forma a empresa busca alcançar e/ou manter sua postura inovativa?

\subsubsection{VARIÁVEIS DA PESQUISA}

De acordo com o objetivo proposto, são variáveis da pesquisa:

- Pequena empresa: as particularidades da pequena empresa, como estrutura simples e orgânica, ausência de padronização dos processos de trabalho, centralização na tomada de decisão, inexistência de processo formal de planejamento e dificuldades na busca de informações externas, entre outras, que terão influência na sua postura inovativa.

- Estilos de gestão: a maneira como os gestores se comportam em relação às tarefas e aos funcionários, seus valores pessoais, a maturidade dos gestores e dos funcionários, o nível do monopólio estratégico e a pressão do tempo sobre as situações cotidianas, que irão definir o modo de atuação dos funcionários.

- Inovação: o ambiente criado e que conduza à aprendizagem, a existência de estratégias para inovação, a participação ativa dos gestores nas ações inovadoras e as condições gerais que impulsionam a inovação, entre outras, e que irão compor o processo de inovação da empresa. 


\subsubsection{TÉCNICA DE COLETA DE DADOS}

A coleta de dados foi realizada por meio de observações, entrevistas nas empresas, análise de documentos, estudo dos aspectos regionais e segmento das empresas pesquisadas.

A observação empregada foi do tipo simples, com postura não interativa do espectador (VERGARA, 2000, p.54). A atenção voltou-se para o ambiente, permitindo ao pesquisador poder certificar-se da presença dos elementos envolvidos na pesquisa.

O formulário constante no Apêndice B foi utilizado na entrevista, apresentado por escrito, mas preenchido pelo pesquisador. Essa técnica é descrita por Vergara (2002, p.55) como favorável para uma maior profundidade na abordagem dos assuntos envolvidos porque permite um melhor entendimento por parte do entrevistado.

\subsubsection{FORMA DE ANÁLISE DOS DADOS}

A pesquisa realizada foi do tipo exploratória e descritiva, de caráter qualitativo. Por esse motivo, a análise foi feita a partir da interpretação dos dados obtidos na pesquisa de campo, confrontando-os com os conceitos e teorias levantadas na pesquisa bibliográfica.

De acordo com Gil (2002), ao contrário do que ocorre com os levantamentos e os estudos experimentais, para o estudo de caso não se pode falar em etapas que devem ser observadas no processo de análise e interpretação dos dados. Isso tende a provocar duas situações distintas, mas igualmente desfavoráveis para a pesquisa. A primeira consiste em finalizar a pesquisa com a simples apresentação dos dados coletados. A segunda consiste em partir dos dados diretamente para a interpretação, ou seja, para a procura dos mais amplos significados que os dados possam ter.

A interpretação dos dados, na forma qualitativa, visa à formação de "categorias de dados" objetivando a compreensão de partes do fenômeno estudado na pesquisa. 
A apresentação dos resultados é dada na forma de relatório onde constam também, entre outros: a descrição dos dados e a transcrição das observações, os métodos de coleta destes dados e as reflexões sobre o cenário atual.

\subsection{DESCRIÇÃO DAS EMPRESAS}

As empresas participantes desta pesquisa são identificadas como empresa A, B e C. A descrição das empresas foi feita com base no questionário de caracterização geral da empresa, apresentado no apêndice $A$.

\subsubsection{EMPRESA A}

A empresa A foi fundada em 1992 e atua no ramo de instrumentos médicos e ópticos, realizando a industrialização e comercialização de topógrafos de córnea, oftalmoscópios binoculares e auto-projetores, entre outros. Os topógrafos de córnea representam em torno de $60 \%$ da sua produção.

Todos os seus seis proprietários são ex-funcionários do Departamento de Física da Universidade de São Paulo, campus de São Carlos, sendo que quatro atuam diretamente na empresa e os outros dois são sócios investidores, cujas atividades são exercidas em outra empresa ligada ao mesmo ramo de atividade da empresa $\mathrm{A}$.

O faturamento anual foi de $\mathrm{R} \$ 1,5$ milhão no ano de 2004, representando um crescimento de $15 \%$ em relação ao ano anterior, motivado principalmente pelo lançamento de novas linhas de produtos e pelo aumento da credibilidade dos produtos de origem nacional na área médico-hospitalar. 


\subsubsection{Estrutura}

Possuindo uma área construída de $600 \mathrm{~m}^{2}$, a empresa emprega 25 funcionários alocados na área operacional e mais 5 funcionários, além dos 4 sócios, na área administrativa. Sua estrutura organizacional pode ser vista no conjunto de organogramas apresentados na Figura 16 e na Figura 17, cujas versões originais foram fornecidas pela empresa na forma impressa e constam no seu sistema de controle administrativo, que é totalmente informatizado.

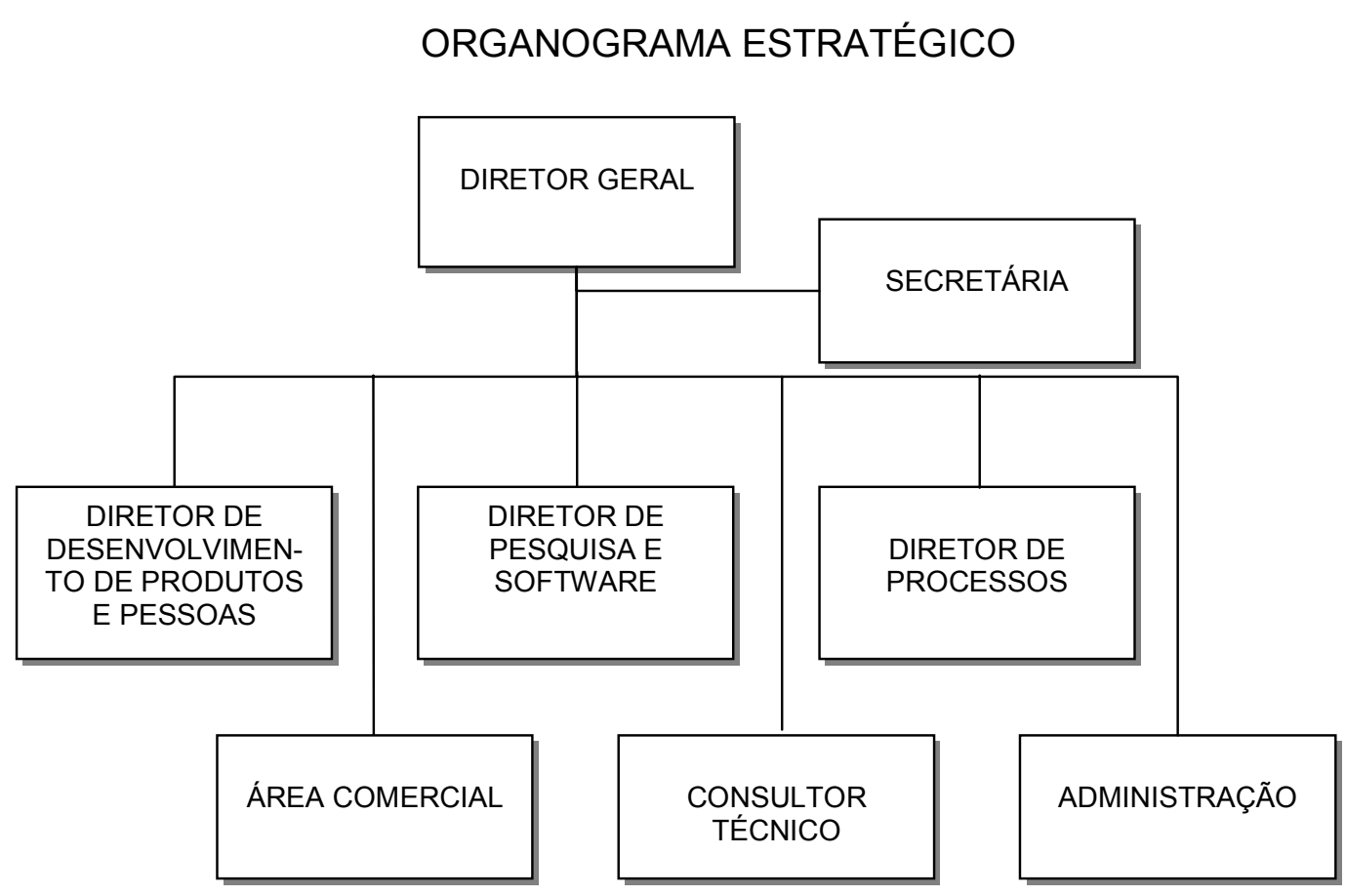

Figura 16: Organograma estratégico.

Fonte: Empresa A.

\subsubsection{Mercado de atuação}

A empresa atua em nível nacional, possuindo $45 \%$ dos seus clientes na região sudeste, $25 \%$ na região nordeste, $15 \%$ na região sul, $10 \%$ na região centro-oeste e $5 \%$ no nordeste. Entre seus principais concorrentes estão as empresas japonesas Topcon Corporation e Medmon, a empresa Huvitz, da Korea e a brasileira Xenônio Industria de Equipamentos Médicos Ltda, que juntas detêm cerca de $55 \%$ do mercado nacional. 
Quanto às características dos seus concorrentes, a empresa A apontou como destaques: a qualidade e diversificação dos produtos, a boa imagem delas no mercado e a grande capacidade de inovação.

Como pontos desfavoráveis, elas apresentam o alto preço dos produtos, em relação aos preços praticados pela empresa $A$, dificuldades de parcelamento dos pagamentos e demora na entrega dos produtos ao cliente.

Os principais fornecedores da empresa A são dois: a Itautec Philco S/A e a Trancham S/A Indústria e Comércio, ambas de São Paulo. O relacionamento de cooperação e a troca de informações técnicas com esses fornecedores são baixos.

FLUXOGRAMA DE TRABALHO

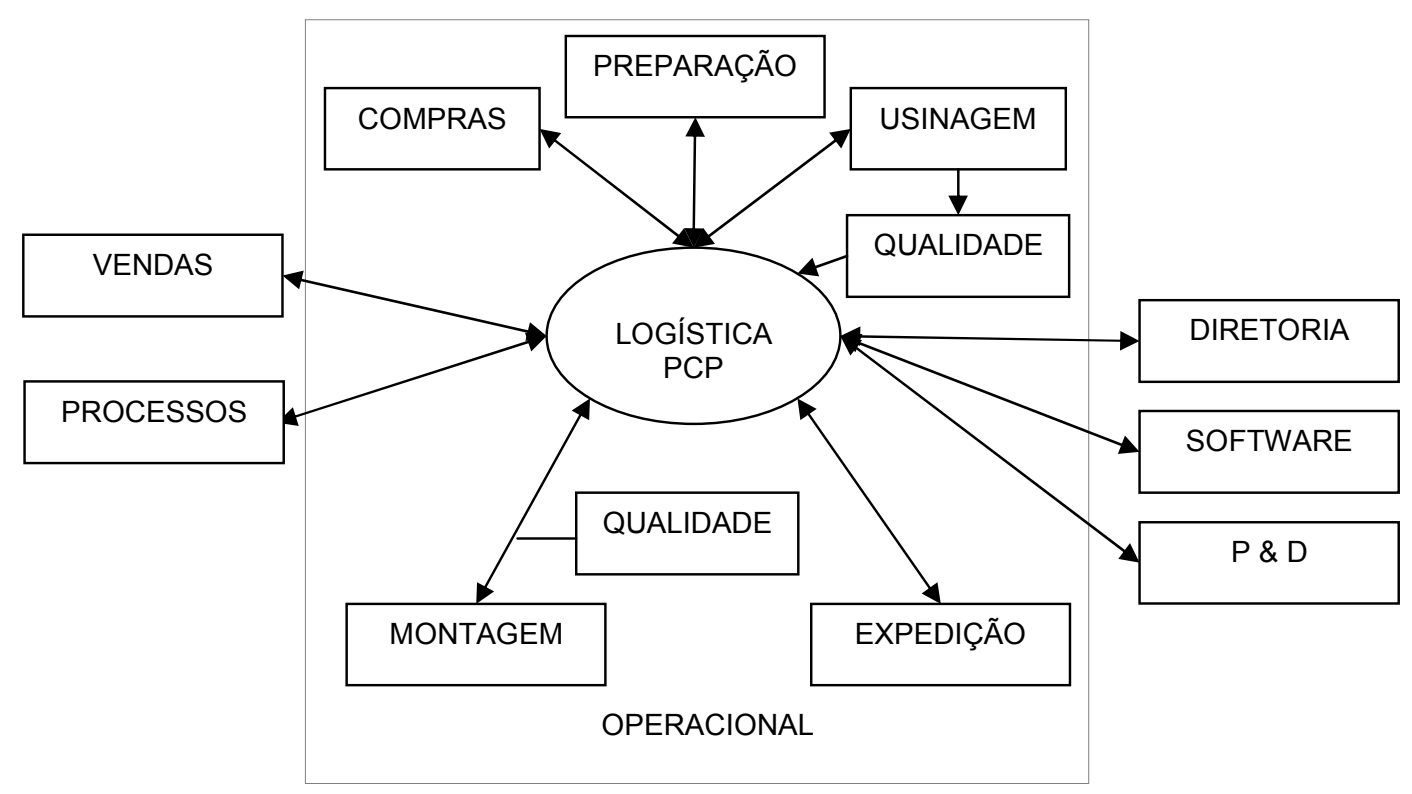

Figura 17: Fluxograma de trabalho Fonte: Empresa A

\subsubsection{EMPRESA B}

Fundada em 1999, a empresa B atua no ramo de automação industrial e agricultura de precisão, realizando a industrialização e comercialização de sistemas de gerenciamento para pulverização de precisão, controladores eletrônicos para carretéis de irrigação, controladores para pivô central e 
controlares elétricos para pulverização. Os controladores eletrônicos para carretéis de irrigação representam em torno de $50 \%$ de toda a sua produção.

A empresa é de propriedade de dois sócios, sendo um deles responsável pela parte administrativa e financeira e o outro pela de projetos.

O faturamento anual em 2004 foi de R\$ 600 mil, sendo em 2003 de $\mathrm{R} \$ 430$ mil e em 2002 de $\mathrm{R} \$ 260$ mil.

\subsubsection{Estrutura}

A empresa emprega atualmente 23 funcionários e está distribuída numa área de $500 \mathrm{~m}^{2}$, próxima ao centro da cidade de São Carlos.

Sem possuir uma estrutura hierárquica rígida, seu corpo funcional é composto em grande parte por estagiários, distribuídos basicamente em torno dos projetos em desenvolvimento.

Suas atividades operacionais estão segmentadas em: desenvolvimento e produção, entendendo-se a primeira como atividades relacionadas à pesquisa e desenvolvimento de novos produtos, melhorias de processos e novos aprimoramentos nos produtos existentes.

Toda a estratégia é definida exclusivamente pelos dois sócios, tomando como base fatores que afetam diretamente o mercado agrícola, tais como a globalização da economia, as políticas governamentais em relação ao segmento agrícola e a projeção cambial.

\subsubsection{Mercado de atuação}

Seus principais clientes localizam-se nos estados de Minas Gerais, Paraná e no estado de São Paulo, com destaque para a Usina Cerradinho, em Lavras, que representa $40 \%$ do seu faturamento, e a empresa Marquesan, de Matão.

Como principais concorrentes, a empresa destacou a AGX Tecnologia, de São Carlos e a Altec Indústria e Comércio de Instrumentos, da cidade de Diadema. As características dos concorrentes, observadas pela empresa $B$ 
foram: a boa qualidade dos produtos, com baixo preço no mercado e a boa imagem que elas têm no mercado.

Seus principais fornecedores são as empresas: Alabarce Comércio e Representação, Micropress S.A., Imep do Brasil Ltda, todas nacionais. Esses fornecedores possuem como destaque a boa qualidade da matéria-prima e bom acesso para troca de informações.

\subsubsection{EMPRESA C}

A empresa C foi fundada em 1998 e atua no ramo de equipamentos ópticos e opto-eletrônicos, produzindo e comercializando fotopolimerizadores de luz fria, sistemas de clareamento dental, laser de baixa intensidade, lentes e prismas, filtros interferenciais e equipamentos médicos de pequeno porte. Sua linha de produtos está segmentada em: equipamentos odontológicos, componentes ópticos e equipamentos médicos. A linha de equipamentos odontológicos representa $80 \%$ do seu faturamento.

Assim como as demais empresas pesquisadas, a empresa $\mathrm{C}$ faz parte do Pólo de Alta Tecnologia de São Carlos e possui bom relacionamento com as universidades e escolas técnicas locais.

A diretoria da empresa $C$ é composta por engenheiros, físicos e extécnicos do Instituto de Física de São Carlos, da Universidade de São Paulo, sendo que o diretor entrevistado é engenheiro.

O faturamento anual da empresa foi de R\$ 5 milhões no ano de 2004, representando um crescimento de $60 \%$ em relação ao ano anterior, que é um comportamento que vem acontecendo desde a criação da empresa e justificado pelo entrevistado como sendo resultado do perfil pioneiro e inovador da empresa. 


\subsubsection{Estrutura}

A empresa possui atualmente 45 funcionários e está distribuída numa área de aproximadamente $600 \mathrm{~m}^{2}$, com uma sede administrativa distinta do setor de produção.

Com uma estrutura hierárquica bem definida, a empresa atende à norma da Legislação Harmônica das Boas Práticas de Fabricação de Produtos Médicos - BPF. Esta norma é aplicada e verificada por meio de inspeções, no âmbito do MERCOSUL, relacionadas com os produtos sob proteção sanitária, chamados de produtos médicos, sendo regida pelo Conselho do Mercado Comum (MERCOSUL, 08/2005).

Sua estratégia é definida exclusivamente pelos sócios, embora haja a participação ativa do corpo funcional na obtenção de informações para definição da estratégia, tanto por meio de pesquisas externas quanto internas entre clientes e fornecedores.

\subsubsection{Mercado de atuação}

Seus maiores clientes localizam-se no interior do estado de São Paulo e no estado de Santa Catarina, atingindo $50 \%$ do seu faturamento.

Como principais concorrentes foram citadas as empresas Condor Tecnologia e DMC, ambas da cidade de São Carlos, e a empresa Dabi Atlante, da cidade de Ribeirão Preto, distante cerca de $100 \mathrm{~km}$ de São Carlos. A participação no mercado e a boa imagem foram citadas como destaque nos seus concorrentes, ficando a qualidade dos produtos, a diversificação e o preço com fatores de menor importância. A demora na entrega dos produtos e a baixa capacidade de inovar foram citadas com fatores negativos da concorrência.

Seus principais fornecedores estão localizados no exterior e destacamse pela qualidade da matéria-prima e pela alta tecnologia de fabricação. Há pouco intercâmbio de informações entre a empresa e seus fornecedores, fator que foi citado pelo entrevistado como sendo de pouca importância para a empresa C. 


\section{CAPÍTULO VI}

\section{APRESENTAÇÃO E ANÁLISE DOS DADOS}

A pesquisa de campo foi realizada utilizando-se do método de estudo de casos, conforme descrito no capítulo 5 . As entrevistas realizaram-se nos meses de maio, junho e julho de 2005 e foram entrevistados três dirigentes, todos envolvidos diretamente com a criação e administração das empresas.

Os resultados e as análises seguem a ordem do roteiro de entrevistas, exposto no Apêndice $B$, que busca um melhor esclarecimento para as questões da pesquisa, definidas na seção 5.3.2.

Um primeiro conjunto, composto de 26 questões, foi aplicado inicialmente com a finalidade de evidenciar melhor a estrutura, estratégia e o ambiente onde a empresa atua. Essas questões iniciais buscam também posicionar a empresa de acordo com os elementos definidos por Mintzberg e Filion, no capítulo 2, seções 2.2.2 à 2.2.5.

\subsection{ORGANIZAÇÃO DE PEQUENAS EMPRESAS}

Em relação à estrutura foram efetuadas doze perguntas com a intenção de esclarecer se existem gestões distintas entre as principais áreas: comercial, administrativa e de produção, como é formada a hierarquia da empresa, como é o processo decisório, como são documentados os processos de trabalho, se 
existe ou não padronização dos métodos de trabalho, onde, efetivamente, situam-se os gestores na estrutura da empresa.

As empresas também foram questionadas sobre o percentual de custos administrativos em relação aos custos totais, tendo a empresa $A$ respondido que existe uma proporção em torno de $12 \%$, a empresa $B$ disse que gira em torno de $20 \%$ e a empresa C não soube definir, mas sabe que não é muito baixo. O alto custo de administração foi destacado por Pzysieznig (1998) como uma das características relevantes da pequena empresa, conforme consta na seção 2.1 - Dificuldades da pequena empresa no Brasil, e que pode limitar as ações ligadas à sua gestão, dizendo ainda que um caminho eficiente para superar esse problema é o próprio crescimento da empresa.

Em resposta a essa questão foi observado, nas três empresas, um crescimento no faturamento em uma proporção média de 15\%, 40\% e 60\% respectivamente. Esse fato pode colaborar para uma melhora consistente nas ações voltadas para a gestão dos processos organizacionais.

Todas as empresas disseram que existem gestões distintas entre as principais áreas, cujas atividades são sempre exercidas exclusivamente pelos sócios. Cabe destacar a resposta dada pela empresa B que definiu a gestão de produtos e desenvolvimento como sendo exercida em conjunto pelos sócios, devido à sua importância estratégica.

Em complemento à questão anterior, foi investigada a existência de descentralização em algum grau no processo decisório das empresas. Essa questão é levantada por Bateman e Snell (1998, p.248) e por Mintzberg (2003, p.113), ambos citados na seção 2.2.3, e possui relevância ao se considerar que isso terá grande influência no comportamento dos funcionários $e$, por conseqüência, irá afetar a motivação e o moral das pessoas que participam dos diversos projetos desenvolvidos nas empresas.

Para a questão acima foi obtido o consenso de que as decisões estratégicas que envolvam investimentos, alterações na estrutura de custos, influência direta na política comercial e mudanças significativas na área de recursos humanos, como demissões, por exemplo, são de exclusividade da diretoria, ficando para os responsáveis da área de produção a maioria das decisões rotineiras. Decisões de alto risco são amplamente discutidas entre os 
sócios, que não buscam amparo externo e são resolvidas mais pela confiança na experiência vivida na prática.

Embora as respostas pareçam definir a questão da descentralização das decisões, ao serem questionados sobre o envolvimento com o trabalho operacional no dia-a-dia das empresas, todos os entrevistados disseram sentir muita dificuldade para se limitarem às atividades estratégicas, ficando ainda muito envolvidos com as questões operacionais e, principalmente, as questões financeiras de curto prazo. Ao serem questionados de forma direta acerca das atividades que mais ocupam tempo dos diretores, as respostas se concentraram mais uma vez nas questões operacionais, mas agora com uma melhor definição sobre o que os entrevistados consideravam como operacional, ficando claro que não se trata de questões relacionadas à produção e ao desenvolvimento dos projetos, mas sim ligadas às áreas: comercial, financeira e administrativa.

O tempo médio para a tomada de decisão é bastante curto, com exceção das questões de alto risco, que são mais amplamente discutidas. A empresa $B$ destacou as decisões que envolvam a obtenção de crédito como as de menor tempo para maturação, salientando os reflexos ruins que podem advir de uma demora excessiva nestes casos como, por exemplo, o atraso no lançamento de um produto que acarretará uma perda na participação de mercado.

Em relação à composição das equipes de trabalho, a empresa $A$ definiu com sendo formadas, geralmente, por um ou dois especialistas e um grupo de auxiliares. As demais empresas pesquisadas formam grupos de trabalho de acordo com a característica do projeto. Cabe destacar que, em todas as empresas investigadas, foi verificada a presença de muitos estagiários bolsistas, advindos das universidades instaladas na cidade de São Carlos e que, no critério de seleção, é bastante ressaltada a capacidade técnica como quesito de extrema importância na hora da escolha de novos funcionários. Desta forma, pode-se inferir que as equipes de trabalho possuem em sua estrutura pessoas com boa capacitação técnica e são formadas de acordo com a definição dada na seção 2.2.4 - As cinco estruturas de Mintzberg, item "e": Adhocracia. Os projetos são desenvolvidos por pequenas equipes multidisciplinares, envolvendo especialistas operacionais e funcionários de 
maior tempo de casa. A preocupação com o cliente foi um fator presente nas três empresas entrevistadas, o que permite maior refinamento na definição de suas estruturas, alinhando-as com a adhocracia operacional, em que há uma união de esforços para apresentar soluções específicas aos clientes.

Sete questionamentos foram feitos em relação à estratégia com a finalidade de identificar se existe algum processo formal de planejamento, quem realiza o planejamento, de que maneira ele é disseminado dentro da organização e como são obtidas as informações necessárias à sua elaboração.

Todos os entrevistados demonstraram conhecer bem os pontos fortes e fracos de suas empresas, como também as ameaças e oportunidades existentes no ambiente onde elas atuam. Essa questão é levantada por Porter (1998) como uma das partes fundamentais para a construção do processo de planejamento. Segundo o trabalho de Resnik (1990), apresentado na seção 2.2.5, quando os proprietários-gerentes de pequenas empresas conseguem compreender os fatores que podem causar o sucesso ou o fracasso da empresa, seus conceitos administrativos os auxiliam na superação das dificuldades que são encontradas.

Os resultados obtidos para essa questão foram os seguintes:

Tabela 4: Pontos fortes e fracos

\begin{tabular}{|c|c|c|}
\hline & Pontos fortes & Pontos fracos \\
\hline Empresa A & - Pioneirismo & $\begin{array}{l}\text { - Conservadorismo nas } \\
\text { decisões que envolvem } \\
\text { investimentos. }\end{array}$ \\
\hline Empresa B & $\begin{array}{l}\text { - Criação. } \\
\text { - Iniciativa. } \\
\text { - Parceiras. }\end{array}$ & $\begin{array}{l}\text { - Tempo muito longo } \\
\text { para conclusão dos } \\
\text { projetos. } \\
\text { - Linha de produtos } \\
\text { pouco diversificada. }\end{array}$ \\
\hline Empresa C & $\begin{array}{l}\text { - Bom relacionamento } \\
\text { com as universidades e } \\
\text { também com seus } \\
\text { clientes. }\end{array}$ & $\begin{array}{l}\text { - Pouca agressividade } \\
\text { da empresa no } \\
\text { mercado. }\end{array}$ \\
\hline
\end{tabular}


Tabela 5: Ameaças e oportunidades

\begin{tabular}{|l|l|l|}
\hline & \multicolumn{1}{|c|}{ Ameaças } & \multicolumn{1}{c|}{ Oportunidades } \\
\hline Empresa A & $\begin{array}{l}\text { - Muita concorrência } \\
\text { externa. } \\
\text { - Baixa aceitação do } \\
\text { produto nacional. }\end{array}$ & $\begin{array}{l}\text { - Ramo de atividade } \\
\text { com pouca concorrência } \\
\text { interna. }\end{array}$ \\
\hline Empresa B & - Concorrência acirrada & $\begin{array}{l}\text { - Boa fase do setor } \\
\text { sucro-alcooleiro. }\end{array}$ \\
\hline Empresa C & - Política cambial. & $\begin{array}{l}\text { - Existência de uma } \\
\text { grande faixa de mercado } \\
\text { ainda não explorada. }\end{array}$ \\
\hline
\end{tabular}

Embora somente a empresa $\mathrm{C}$ tenha citado o relacionamento com as universidades como um ponto forte, todas as empresas entrevistadas possuem fortes laços de parceria com as universidades e com os órgãos de fomento à pesquisa no Brasil, como a FAPESP ${ }^{21}$, tendo sido beneficiadas por diversas vezes com recursos advindos do Programa de Inovação Tecnológica em Pequena Empresa - PIPE. Esse programa foi criado 1997, com o objetivo de apoiar o desenvolvimento de pesquisas inovadoras a serem executadas em pequenas empresas sediadas no Estado de São Paulo, e que envolvam importantes problemas em ciência e tecnologia, com alto potencial de retorno comercial ou social (FAPESP, 08/2005).

Ao serem apresentadas questões mais específicas acerca do planejamento, como a forma na qual são traçadas as metas na empresa e quais procedimentos são utilizados para documentar as decisões estratégicas, todos os entrevistados declararam não haver um processo formal de planejamento e que as decisões são tomadas de acordo com as necessidades que vão surgindo no dia-a-dia das empresas.

A determinação de qual é o negócio da empresa foi muito bem definida pelos entrevistados das três empresas. A empresa $C$, inclusive, possui sua missão declarada no site institucional ${ }^{22}$ : "ser uma empresa líder em qualidade e

\footnotetext{
${ }^{21}$ FAPESP - Fundação de Amparo à Pesquisa do Estado de São Paulo.

${ }^{22}$ A referência para esse dado não pode ser apresentada para não expor o nome da empresa.
} 
confiabilidade, com produtos e serviços competitivos capazes de gerar riquezas e continuidade com crescimento sustentado".

Quando questionados sobre a origem das informações estratégicas que levam a empresa a obter vantagem competitiva, os entrevistados citaram como fonte principal os seus próprios clientes, com os quais eles mantêm contato constante para melhorias nos produtos existentes. A empresa A ressaltou também a participação em feiras e congressos, que trazem informações sobre o mercado e auxiliam na criação de novos produtos e no aperfeiçoamento dos atuais produtos.

Finalizando esse tópico, foram efetuadas mais sete questões, relativas ao ambiente onde a empresa atua, buscando definir o grau de estabilidade e certeza existentes, a capacidade da empresa em influenciar esse ambiente, a forma de atuação da concorrência e a força dos clientes, fornecedores e concorrentes.

Ao serem questionados sobre o ambiente onde as empresas atuam os entrevistados das empresas A e C avaliaram como sendo de comportamento moderado, ou seja, sem oscilações muito constantes. Para a empresa $B$, que se difere das outras por não atuar no segmento de equipamentos médicos, o ambiente oferece riscos associados ao clima e a produtividade da safra no Brasil e no exterior, como também a política cambial, que afeta diretamente a exportação dos produtos agrícolas. As três empresas afirmaram que não há como criar ações isoladas que interfiram no ambiente onde elas atuam e que o mercado é que define as regras.

Em relação à concorrência, os entrevistados foram unânimes em definir como extremamente acirrada, não sendo possível identificar nenhum tipo de ação de cooperação ou troca de experiência entre empresas do mesmo segmento. A competição com empresas do exterior incomoda de forma mais acentuada as empresa A e C devido ao mercado de atuação com tradição em produtos importados.

Quando questionados sobre o diferencial da empresa em relação aos seus principais concorrentes, a empresa A definiu como sendo o custo de seus produtos, e as demais como sendo o alto grau de tecnologia empregado e a parceria com seus clientes para o desenvolvimento, em conjunto, de produtos que apresentem boas soluções para suas necessidades. 
A relação de confiança e o espírito de parceria com os clientes, que foi novamente levantado, aparecem como pontos positivos na relação comercial da empresa com seus clientes e fornecedores. A empresa B disse que o fato de fabricar componentes que irão fazer parte dos produtos de seus clientes é um ponto que estimula muito essa parceria, pois implica a existência de uma relação direta entre a qualidade de seu produto e a boa avaliação final dos produtos por seus clientes.

\subsection{ESTILOS DE GESTÃO MAIS EVIDENTES NAS EMPRESAS}

Foram efetuadas vinte perguntas para avaliar os estilos de gestão presentes nas empresas, com a intenção de alinhá-los aos estilos apresentados no capítulo 3.

Para melhor esclarecer essa questão foram verificados, entre outros: a maturidade dos funcionários e o interesse pelas tarefas que executam, o grau de maturidade dos gestores e seus valores pessoais, o interesse dos gestores pelas questões pessoais de seus funcionários, o grau de atenção dos gestores em relação às tarefas a serem executadas.

Como a maturidade do funcionário é uma das variáveis que compõem a teoria do Ciclo de Vida da Liderança de Hersey e Blanchard (1974), citada na seção 3.2.1, e um dos objetivos da pesquisa é verificar os estilos de liderança encontrados nas empresas, foram formuladas questões para avaliar o grau de independência com o qual eles são capazes de executar suas tarefas.

O ambiente encontrado nas empresas e descrito pelos entrevistados aponta para um alto grau de independência dos funcionários em relação à maneira como as tarefas devem ser realizadas. Fica essa liberdade condicionada apenas a algumas regras relativas à qualidade final do produto. $A$ empresa A ressaltou que essa independência para a execução do trabalho é estimulada e possui bons reflexos no prazo de conclusão das tarefas.

As empresas $\mathrm{B}$ e $\mathrm{C}$ disseram que uma das poucas regras que devem ser rigorosamente observadas diz respeito ao tempo médio para o desenvolvimento dos projetos. Embora na empresa $\mathrm{C}$ existam procedimentos $\mathrm{e}$ instruções de trabalho criados para nortear as ações na execução de tarefas 
ligadas à produção, existe grande tolerância para adaptação dessas regras ao modo como o funcionário executa o trabalho.

Com base nas respostas apresentadas e nos comportamentos descritos pela teoria Ciclo de Vida da Liderança, de Hersey e Blanchard (1974), é possível concluir que existe, nas empresas entrevistadas, um alto grau de maturidade nos funcionários.

Quando questionados sobre como é possível perceber o interesse do funcionário pela tarefa que executa, os entrevistados responderam que o interesse fica evidente quando o funcionário busca soluções sozinho. Procura conhecimento até mesmo fora da empresa, quando possui entusiasmo pela execução e pelos resultados do projeto. Funcionários que se preocupam somente com a execução da tarefa foram classificados como desinteressados.

As respostas obtidas demonstram que não só existe o interesse dos funcionários pelas tarefas que executam como também os gestores possuem consciência da existência de elementos que identificam esse interesse. Esse relato, por parte dos entrevistados, traz mais consistência para as respostas obtidas, visto que os comportamentos relatados foram dados como presentes nas três empresas.

A fim de que fosse possível verificar a orientação dos gestores para tarefas ou para o relacionamento com seus funcionários que, junto com a variável maturidade, aparecem na matriz de "Estilos Eficientes" apresentada por Hersey e Blanchard (1974) e está constante na seção 3.2.1, foram colocadas questões relacionadas à preocupação dos gestores com o atingimento das metas traçadas, assim como questões referentes ao contato desses gestores com seus subordinados na solução de questões pessoais. As três empresas declararam buscar o atingimento das metas colocando aos seus funcionários desafios relativos à qualidade dos produtos e ao prazo de conclusão dos projetos. O entrevistado da empresa $A$ disse que um grande desafio anual é atingir bons resultados no Congresso Brasileiro de Oftalmologia e que todos os funcionários são estimulados a dar sua contribuição. A empresa $B$ disse que, como a maioria de seus funcionários são estagiários bolsistas, seus projetos individuais são também considerados como parâmetro para o sucesso no alcance dos objetivos. 
Embora tenha sido demonstrada preocupação com o atingimento das metas traçadas, os entrevistados declararam não haver pressão direta sobre seus funcionários para que o trabalho seja executado dentro de um tempo determinado, e que essa postura nunca fez parte da cultura da empresa porque existe o comprometimento dos funcionários com as tarefas a serem executadas.

Em relação às questões pessoais, a empresa $A$ disse que é dada a devida atenção, seja para dificuldades financeiras com também para aquelas relacionadas à saúde do funcionário e de seus familiares, ou para qualquer outro problema que venha a surgir. A empresa, além de adiantar salários, possui um sistema formal de empréstimos, que podem ser solicitados quando necessário. Essa atenção dada para as questões pessoais ficou bastante evidente devido a um fato ocorrido com um funcionário da empresa. Durante o período das entrevistas, ele sofreu um acidente fora do horário de trabalho e passou a receber visitas diárias do entrevistado, que possui a função de diretor geral.

Na empresa B, existe uma preocupação em levantar a solução proposta pelo funcionário e, tal como na empresa $C$, o problema é tratado inicialmente com o líder de equipe, que tem a função de auxiliar o funcionário na busca da solução mais adequada. Após esse procedimento, é montada uma proposta para análise da diretoria. Nestes casos, portanto, existem regras a serem observadas e uma maior formalização. Apesar do aspecto burocrático, ambas disseram que existe a preocupação em solucionar o problema de maneira rápida.

O resultado obtido demonstra uma preocupação dos gestores entrevistados com as questões levantadas por Likert (1979) e apresentadas na seção 3.2.2, que enfatiza a importância do comportamento de relacionamento para obtenção de um alto desempenho.

Um fator presente na abordagem situacional da liderança e descrito por Tannembaum e Schimdt ${ }^{23}$ (apud BATEMAN e SNELL, 1998), relacionado às forças que atuam no administrador, foi verificado, por meio de questões que buscaram levantar o perfil dos funcionários que ocupam cargos de chefia. As

\footnotetext{
${ }^{23}$ TANNENBAUM, A. SCHMIDT, W. (1958). How to choose a leadership pattern. Harvard Business Review, 36, p.95-101, Mar/Apr.
} 
empresas A e B disseram dar preferência para promoção ou contratação de indivíduos que demonstrem habilidades de relacionamento interpessoal, ficando em segundo plano, mas não menos importantes, as habilidades técnicas. A empresa $\mathrm{C}$ declarou que prefere promover os funcionários internos, mais experientes, ao invés de contratar pessoas de fora. Justifica essa prática por acreditar que, desta forma, pode criar um sentimento de mais segurança e comprometimento entre seus funcionários.

Em complemento à questão anterior, foi solicitado aos entrevistados que avaliassem seus atuais gerentes, os quais foram considerados "comprometidos com a empresa, responsáveis, de bom relacionamento pessoal e capacitados para a função que exercem".

Seguindo a linha de pesquisas de Fiedler ${ }^{24}$ (apud Hampton, 1990), contida na seção 3.2.3, pode-se concluir que a administração das empresas pesquisadas é facilitada pela boa relação existente entre os gerentes e seus funcionários.

Pelas características estruturais apresentadas pelas três empresas e descritas em questões anteriores, bem como pelo objetivo dessa pesquisa, serão considerados como gestores somente os seus proprietários, visto que os gerentes, não proprietários, possuem atuação restrita ao setor de produção.

Os requisitos para que um funcionário seja promovido na empresa foram verificados para que, junto com a participação dos gerentes no processo e com o tipo de recompensa para o bom desempenho, formassem os elementos necessários para investigar os estilos motivacionais descritos por Maximiano (2004, p.303) na seção 3.2.4, que são divididos entre o carismático e o transacional.

Quanto aos requisitos para promoção, os critérios mais presentes foram: possuir bom relacionamento com os colegas no trabalho, bom conhecimento técnico e envolvimento com os diversos projetos existentes na empresa. A promoção aparece como uma das principais formas de recompensa descritas pelas três empresas, juntamente com outras tais como: maior presença em atividades ligadas a área comercial, comparecimento às feiras e congressos nos quais a empresa participa e maior atuação nos processos decisórios.

${ }^{24}$ FIEDLER, F. E. (1967). A theory of leadership effectiveness. New York: McGraw-Hill. 
Colocadas desta forma, as questões remetem a uma classificação intermediária, entre o carismático e o transacional, pois o crescimento pessoal ligado à liderança carismática se torna presente quando a empresa proporciona uma maior aproximação do funcionário com os processos decisórios e permite a sua participação em atividades externas da empresa. Por outro lado, a promoção recebeu grande destaque nas três empresas, deixando evidente que um meio de troca monetário, descrito como uma das principais características da liderança transacional, é largamente aplicado.

\subsection{COMO O GESTOR CONTRIBUI PARA O PROCESSO DE INOVAÇÃO}

Foram feitas treze perguntas para identificar a influência do gestor em atividades que possuem relação com processos de inovação e aprendizado. Para tal, foram levantadas informações relativas a: ações motivadoras para idéias de novos produtos e melhorias nos processos da empresa, criação de condições para que os funcionários opinem sobre produtos e processos da empresa, elaboração de critérios para contratação, influência na composição das equipes de trabalho, existência de intercâmbio de informações entre gestores e funcionários, divulgação de informações estratégicas.

As respostas apresentadas para questões ligadas às atividades dos gestores e que possam encorajar os funcionários a serem inovadores não possibilitaram identificar nenhuma ação direta por parte destes gestores. A inovação é vista como algo importante que deve estar na consciência do funcionário e direcionar suas ações, porém, segundo o relato dos entrevistados, não há nenhum sistema de recompensas por resultados que estejam ligados diretamente a ações inovadoras, ficando as recompensas restritas ao alcance das metas de produção. A empresa $A$ ressaltou que 0 clima gerado pelo Congresso Brasileiro de Oftalmologia é algo que estimula novas idéias na empresa, principalmente por ser uma oportunidade de manter contato com novas tecnologias que, talvez, ainda não estejam no mercado. A empresa $C$ disse que a motivação para inovar é um atributo pessoal e que alguns funcionários apresentam essa aptidão. 
Quando questionados sobre quanto tempo em média um funcionário não ligado a P\&D pode se dedicar ao desenvolvimento de novas idéias, a empresa A disse que "eles ficam atentos o tempo todo e estão sempre aprimorando seus processos". Para as outras duas empresas, o ambiente de alta tecnologia existente é um estímulo para inovar. Na empresa B existe uma rotina em que os funcionários passam alguns meses no departamento de desenvolvimento para aprenderam mais sobre os produtos.

Observou-se desta forma que, nas empresas entrevistadas, os gestores esperam que seus funcionários desenvolvam sozinhos o perfil descrito por Schuler e Jackson (1995) na seção 3.3 e que são resumidamente definidos como: alto grau de comportamento criativo, relativo alto grau de cooperação e comportamento interdependente, moderado nível de preocupação com a qualidade, um nível de preocupação equivalente para processos e resultados e um alto grau para tomada de ação de risco.

Schuler e Jackson (1995) ressaltam que essas ações devem fazer parte da estratégia de empresas que adotam a inovação, devendo portanto serem de responsabilidade dos seus gestores.

Para que essa questão fosse mais bem esclarecida, tornou-se necessária uma outra questão: como os gestores conseguem criar situações que estimulem idéias e sugestões? Todas as empresas ressaltaram a existência de ações que estimulam o funcionário a ter contato mais próximo com o mercado onde elas atuam, na forma de participações em feiras e congressos, contato direto com seus clientes e discussão interna de problemas relacionados aos seus produtos.

Quando questionados sobre a freqüência com que surgem novas idéias para melhoria de produtos e processos, todas responderam que esse é um processo contínuo e que os melhoramentos estão sempre relacionados à execução dos projetos.

Nota-se, portanto, que embora haja certa preocupação dos gestores em estimular seus funcionários para que tenham novas idéias, não existe uma sistematização de atividades que estejam ligadas aos princípios definidos por Sutton (2002) na seção 3.4 para a quebra da rotina e exploração de novas possibilidades. 
Reforçando essa questão, a empresa A declarou que hoje não há espaço para testar algo muito radical porque o mercado atual possui padrões muito bem definidos e já estabelecidos.

Quando questionados sobre a possibilidade de contratação de pessoas com cultura muito diferente daquela existente na empresa, somente a empresa C se mostrou favorável, embora não tenha nenhum exemplo no momento. Essa questão é vista como importante por Sutton (2002), para que haja uma quebra de conhecimentos e crenças de uma empresa.

Os conceitos apresentados por Leonard-Barton (1998) na seção 3.4, combinados com a resposta apresentada acima, reforçam a idéia de que as empresas ainda conservam muitas atitudes definidas como inibidoras do processo de inovação e criação de novo saber, o que faz com que elas corram os riscos de ruptura de mercado apresentados na argumentação de Christensen (2002) e constantes na seção 3.4. Com o pressuposto de que o futuro seja parecido com o passado, as empresas se concentram em fazer coisas melhores, e não diferentes do que já fazem.

Para que fosse possível investigar as proposições feitas por Hamel e Skarzynski (2001), apresentadas na seção 3.4, que dizem respeito à quebra do monopólio estratégico, quatro questões foram levantadas. O intercâmbio de informações entre administradores e funcionários acerca de assuntos estratégicos foi declarado como presente para questões que envolvam assuntos relacionados aos produtos e ao mercado. No entanto não há intercâmbio para assuntos mais críticos, que envolvam, principalmente, questões financeiras.

A busca de novas visões de negócios, que envolvam mudanças mais significativas na estratégia da empresa, também fica restrita a diretoria e ocorre geralmente entre a empresa e seus clientes. A empresa $C$ possui um processo mais amplo para essa questão e disse que seus diretores têm o hábito de consultar publicações em periódicos e freqüentar centros de pesquisa, como também realizam, constantemente, viagens para participação em congresso e eventos relacionados ao segmento em que atuam.

Embora os assuntos estratégicos não sejam discutidos na amplitude recomendada por Hamel e Skarzynski (2001), a empresa C acredita que seus funcionários sentem-se parte do processo estratégico porque vêem o resultado 
do seu trabalho através de uma cultura de feedback, proporcionada pela diretoria. Esta possui o hábito de promover encontros entre seus funcionários e seus clientes para discutirem o resultado final de seus projetos.

As empresas A e B também demonstraram a presença de ações que fazem com que seus funcionários se sintam parte do processo, pois, na maioria das vezes, as informações são repassadas a todos, principalmente quando relacionadas aos projetos. Hamel e Skarzynski (2001) ressaltam que, quando as pessoas são partes do processo, seu desempenho é bem maior.

\subsection{DE QUE FORMA A EMPRESA BUSCA ALCANÇAR E/OU MANTER SUA POSTURA INOVATIVA}

Trinta questões foram levantadas para verificar a presença, na empresa, de elementos voltados para atividades que levam a inovação de produtos ou processos, e qual o efeito disso para o sucesso da empresa.

Essas questões buscam identificar: presença de ambiente que conduza ao aprendizado, existência de atividades internas de treinamento, elaboração de estratégias para inovação, quantidade investida em pesquisa e desenvolvimento, participação da empresa em programas de estímulo à inovação, vínculo estável com empresas maiores, presença de manuais e normas internas, existência de uma filosofia empresarial, percepção dos clientes em relação às inovações implementadas pela empresa.

As três empresas declararam que sempre buscam, no mercado, pessoal já qualificado para a função a ser exercida e que os novos funcionários, portanto, sempre possuem boa capacitação técnica. $O$ entrevistado da empresa $A$ disse que, em princípio, é dada uma visão geral da empresa e depois um treinamento para o cargo a ser ocupado. A empresa B declarou que os novos funcionários sempre são direcionados para projetos já em andamento na empresa. Quando questionados sobre as oportunidades criadas para que os novos funcionários troquem informações com os mais experientes, as empresas declararam que esse é um processo natural que ocorre no dia-a-dia e de acordo com as necessidades que vão surgindo, não havendo em nenhuma das empresas uma sistematização desse processo. 
Os programas de treinamento são praticados na empresa A quando ocorre o lançamento de um novo produto. Nessa oportunidade são feitos treinamentos técnicos e de vendas. $\mathrm{Na}$ empresa $\mathrm{B}$, são realizados treinamentos na cidade de São Paulo, somente para manipulação dos micro controladores, que são os componentes-chave para a maioria dos seus produtos. Também são utilizados recursos de busca pela internet e a participação dos funcionários em fóruns de discussões na internet. Na empresa C, os treinamentos são conduzidos pelos funcionários mais experientes, sendo feitos a cada dois ou três meses.

Quando questionados sobre 0 atendimento a solicitações de treinamento, os entrevistados declararam que atendem, sempre que possível, desde que sejam treinamentos especificamente técnicos e dentro da área de atuação do funcionário.

Observa-se aqui que não há como identificar ações relacionadas ao que Certo (2003) define como abordagem da organização que aprende, apresentada no item 1.1. A preocupação central dos gestores no processo de aprendizagem é trazer pessoas que já detenham o conhecimento necessário para a função, limitando-se somente a adaptá-los à rotina existente na empresa, ou incorporá-los aos projetos já em andamento. Espera-se que a troca de informações aconteça de forma natural, havendo pouco estímulo por parte da empresa, que se limita a oferecer treinamentos internos com baixa periodicidade e focados, na sua grande maioria, nos aspectos técnicos, contrariando o que definem Schuler e Jackson (1995), citados no item 1.2, que dizem ser necessário pensar além das habilidades técnicas para que se concretize o processo de inovação.

Perguntados sobre a existência de algum banco de sugestões nas empresas, os entrevistados disseram que não há essa prática e que a maioria das sugestões são feitas pelos próprios clientes. A empresa A disse que realiza um concurso anual para premiar idéias e sugestões criativas, assim como a empresa $C$, que também remunera em dinheiro idéias que contribuam para inovações e melhorias nos produtos.

Essas ações possuem um alinhamento com 0 que foi exposto por Perussi Filho (2001), citado no item 4.6, que ressaltam a cultura de P\&D informal existente nas pequenas empresas, onde se destacam, principalmente, 
ações ligadas a inovações incrementais, com ênfase no processo de adaptação de novos produtos ou serviços, para que sejam mais adequados aos seus consumidores. Esse processo é, em grande parte, facilitado pelo que foi apresentado por Terence (2002) como uma das vantagens da pequena empresa em relação às grandes corporações, que é sua maior capacidade de adaptação às mudanças na realidade empresarial. Rothwell e Dodgson (1993), citados no item 4.6, também ressaltam que as pequenas empresas possuem vantagens comportamentais relacionadas à sua maior flexibilidade e capacidade de adaptação a mudanças no mercado.

A pesquisa e o desenvolvimento de produtos nas empresas são, em grande parte, financiados por fundações como a Fapesp ${ }^{25}$ e a Finep ${ }^{26}$, sendo que, na empresa $B$, as pesquisas também são financiadas por alguns clientes. Em relação ao faturamento, são gastos na empresa $A$ cerca $10 \%$ com P\&D e, na empresa C, em torno de $6 \%$ do faturamento. Já a empresa B gasta aproximadamente $\mathrm{R} \$ 200.000,00$ ao ano com $P \& D$, custeados praticamente na sua totalidade por recursos das Fundações e pelos seus clientes.

Questionadas sobre a existência de atividades ligadas diretamente ao desenvolvimento de novos produtos ou novos processos, as empresas A e C disseram que novos produtos são desenvolvidos, principalmente, por pressão da concorrência. Diferentemente da empresa $B$, que adota o conceito de projetos baseados, principalmente, em pesquisas de tendências de mercado ou quando os clientes sugerem melhorias nos produtos atuais. Para essa questão é necessário ponderar que as empresas $A$ e $C$ atuam em um mesmo segmento. Já a empresa $B$ atua no ramo de automação industrial e de agricultura de precisão, portanto, é de se esperar que as forças de mercado sejam diferentes entre elas.

Resgatando o que disse La Rovere e Medeiros (2000), citados no item 4, as empresas entrevistadas realmente dependem de fatores ligados à organização do setor e ao sistema de inovações de onde elas se encontram. E os programas ligados à política de inovação estimulam e auxiliam bastante os processos de P\&D existentes.

\footnotetext{
${ }^{25}$ Fundação de Amparo à Pesquisa do Estado de São Paulo.

${ }^{26}$ Financiadora de Estudos e Projetos. Empresa pública vinculada ao Ministério da Ciência e Tecnologia.
} 
Para investigar o que Sabbag (2000) definiu como "trabalhadores do conhecimento", citado no item 4, foi-lhes perguntado sobre as atividades que se tornam mais eficientes para o aprendizado individual. As empresas declararam que o aprendizado do funcionário ocorre na prática do dia-a-dia, quando eles devem lidar com problemas diversos. Todos necessitam convergir para um pensamento colaborativo referentes às necessidades do grupo e com as estratégias definidas para os projetos. A organização das equipes de trabalho é geralmente realizada por afinidade de tarefas e os funcionários são escolhidos de acordo com as habilidades necessárias para o desenvolvimento do projeto. Nas três empresas entrevistadas, seus gestores disseram que os funcionários apresentam boa capacidade de lidar com os problemas de maneira autônoma ou auxiliados pela equipe de trabalho, além de demonstrarem grande envolvimento com os resultados a serem alcançados.

A participação dos gestores em feiras e congressos é citada como prática habitual e essencial nas três empresas. Nessas participações é adquirida grande parte das informações necessárias para o aprimoramento de seus produtos. A empresa A participa anualmente do Congresso Nacional de Oftalmologia, para o qual seus diretores conservam o hábito de escrever e enviar artigos científicos. A empresa B participa da Agrishow $^{27}$, em Ribeirão Preto - SP e de todos os eventos promovidos pela Unicamp e pela Embrapa. A empresa C dá ênfase ao Congresso Internacional de Odontologia de São Paulo, além de participar de eventos mensais, por meio de seu departamento comercial.

La Rovere e Medeiros (2000), citados no item 4, ressaltam a importância da presença de vínculos estáveis entre as pequenas e as grandes empresas para obtenção de informações técnicas. Em relação às empresas entrevistadas, pôde ser constatada essa presença. A empresa A vincula-se aos seus grandes clientes, de maneira formal, para o desenvolvimento de projetos, principalmente para universidades e hospitais, com destaque para o Hospital das Clínicas de Ribeirão Preto.

\footnotetext{
${ }^{27}$ Feira Internacional de Tecnologia Agrícola realizada pela ABAG - Associação Brasileira de Agrobusiness e patrocinada pelo Ministério da Agricultura, Pecuária e Abastecimento, com o apoio institucional do governo do Estado de São Paulo.
} 
A empresa B também possui grande relacionamento com seus clientes, para os quais ela desenvolve projetos em parceria e cujas despesas são rateadas na proporção de $50 \%$.

Somente na empresa $C$ esses vínculos não foram declarados como relevantes, ficando o desenvolvimento de produtos mais a cargo da própria empresa. Cabe observar que sua mão-de-obra é composta principalmente por estagiários, ligados às Universidades de São Carlos e região, e que isso, por si, favorece a obtenção de grande quantidade de novos conhecimentos para a empresa.

A capacidade de criação de novos conhecimentos, sua difusão, internalização, disseminação e memorização, definidos por Nonaka (1997) e citados no item 4.1 , foram investigados para que fosse possível verificar a presença de um ambiente que favorecesse o processo de aprendizagem.

Quase nenhum material relacionado à normatização de processos de desenvolvimento pôde ser identificado nas empresas, porém todas possuem manuais organizacionais, normas relacionadas à qualidade e manuais técnicos de fácil acesso, o que permite identificar uma relativa preocupação em tornar explícitos os procedimentos e técnicas empregadas no desenvolvimento e na produção dos seus produtos.

O senso de grupo, a ética e o respeito, o foco na satisfação do trabalho e a transparência no desenvolvimento de novas idéias foram valores bastante ressaltados pelos entrevistados e ditos como presentes no cotidiano das empresas, permitindo um alinhamento com as estratégias de aprimoramento do conhecimento definidas por Sabbag (2000) e citadas no item 4.1. Permitem também a presença de fatores citados por Nonaka (1997) como indispensáveis para a transformação de conhecimento tácito em conhecimento explícito, definidos na seção 4.1 .

A empresa A tem encontrado dificuldades para o compartilhamento de informações entre seus trabalhadores, embora declare que eles estejam bastante comprometidos com os resultados da empresa. O entrevistado da empresa $A$ atribuiu esse fato à grande competitividade existente no mercado de mão-de-obra para o seu segmento, e disse que vem tentando superar essa limitação oferecendo oportunidades de crescimento profissional para os seus funcionários com base no comportamento de equipe deles. 
Em todas as empresas foi observado que a necessidade de superar metas e o foco no desenvolvimento em equipes de projeto acaba por favorecer a troca de conhecimentos entre os mais experientes e os funcionários mais novos, levando ao processo de combinação de conhecimentos definido por Nonaka (1997) no item 4.1.

Para que fosse possível esclarecer a questão levantada por Porter (1998), citada no item 4.2, que diferencia novidade de inovação, foi perguntado às empresas quais melhorias geralmente atraem mais seus clientes. A empresa B disse que melhorias que equilibram custo e qualidade são mais elogiadas pelos seus clientes, ficando os clientes das empresas A e C mais voltados para o acabamento e a precisão no diagnóstico. Pode-se compreender melhor essa questão considerando que os produtos produzidos pelas empresas $A$ e $C$ são direcionados aos consumidores finais - profissionais das áreas médica e odontológica, e os produtos da empresa $B$ são componentes a serem utilizados em outros produtos, emergindo daí a preocupação dos clientes com o custo e a qualidade. De qualquer forma é possível afirmar que os clientes das empresas entrevistadas possuem uma boa capacidade de julgamento em relação às inovações incorporadas aos seus produtos.

Todas as empresas apresentam processos de melhoria contínua em seus produtos, motivadas, principalmente, por pressão do mercado na busca de preços mais competitivos, aliados às exigências crescentes em relação à qualidade dos produtos. Essa necessidade obriga as empresas a desenvolverem ações que possam equilibrar a relação custo/diferenciação, definida por Porter (1998) e citada no item 4.5.1. Das três empresas, somente a empresa $\mathrm{C}$ declarou atender projetos sob encomenda, com exclusividade para determinados clientes, como hospitais.

Questionados acerca do que faz com que a empresa seja mais competitiva no mercado, os destaques foram para a agilidade na conclusão dos projetos, a proximidade com os clientes, o pós-venda e a assistência técnica, o prazo de entrega e, por fim, a tecnologia empregada

O estímulo para inovar foi declarado como um componente, na maioria das vezes, ligado à necessidade dos clientes atuais. Somente a empresa $\mathrm{C}$, que embora tenha dito que também possui foco em inovações direcionadas 
para os seus clientes atuais, destacou ações internas que antecipam necessidades de mercado. Atribuiu tal atitude ao ambiente interno, composto, na sua maioria, por estagiários ligados às universidades da cidade de São Carlos e região, possuidores de grande criatividade e amparados pelos seus institutos de pesquisa.

As questões acima permitem identificar o que Gagnon e Toulouse (1996) descreveram como a postura das pequenas empresas. Elas introduzem inovações somente quando percebem oportunidades de negócios ligadas à inovação ou, então, porque estão sob pressão de seus clientes. Eles atribuem este fato ao processo de aprendizado tecnológico das pequenas empresas. 


\section{CAPÍTULO VII}

\section{CONSIDERAÇÕES FINAIS}

Conforme descrito nos capítulos precedentes, para que a pequena empresa torne-se mais competitiva no cenário econômico atual, é necessário pensar sobre os problemas que as atingem de forma particular.

A nova escala de produção mundial, aliada ao crescente avanço tecnológico, aponta para um mercado cada vez mais complexo e dinâmico, onde flexibilidade, velocidade e capacidade de adaptação a novas demandas tornar-se-ão, cada vez mais, o grande diferencial das empresas. Portanto, a estratégia na nova economia deverá incorporar a inovação como um fator de continuidade da empresa.

A capacidade inovativa das empresas está geralmente associada à sua gestão. Identificar os comportamentos presentes nas pequenas empresas inovadoras pode levar ao desenvolvimento de práticas que levem outras pequenas empresas a também se tornarem inovadoras.

Este trabalho foi desenvolvido com a intenção de apresentar os estilos de gestão encontrados nas pequenas empresas pesquisadas e identificar a existência de componentes com efeito na postura inovativa destas empresas.

O presente capítulo apresenta as conclusões da pesquisa visando atingir seus objetivos, como também procura responder ao problema que a originou.

Para tornar mais clara sua apresentação e facilitar a leitura, a seqüência apresentada no capítulo anterior será repetida, ficando então este capítulo divido também em quatro seções, porém com uma última seção adicional, 
destinada às considerações acerca das contribuições da pesquisa, suas limitações e, por fim, trazer uma sugestão para trabalhos futuros.

\subsection{ORGANIZAÇÃO DE PEQUENAS EMPRESAS}

A maneira como as empresas buscam novos profissionais deixa evidente a grande necessidade de qualificação do trabalhador que, diferentemente do modelo fordista, necessita de grande habilidade técnica para lidar com novas situações que venham a surgir, motivadas pela constante adequação das empresas às demandas que surgem.

A padronização dos processos é enfraquecida pela flexibilidade exigida pelo mercado, o que reduz as vantagens que poderiam surgir com a especialização. A grande presença de estagiários, ligados às universidades, denota uma nova relação de trabalho, em que a definição de cargos torna-se pouco relevante para a manutenção de um ambiente motivador, ficando o foco dos interesses mais voltado para o sucesso dos projetos executados e sua contribuição para o desenvolvimento pessoal do trabalhador.

A ausência na troca de informações e experiências entre as empresas do mesmo segmento dificulta muito a obtenção de conhecimento externo, obrigando-as a confiarem na experiência e no conhecimento adquirido pelos seus proprietários e funcionários. Obrigadas a buscar a padronização das habilidades dos trabalhadores, as empresas inibem a possibilidade de criação de um quadro de funcionários multidisciplinar que pode favorecer processos inovadores na empresa.

Não há delegação de autoridade para a tomada de decisões estratégicas nos níveis mais baixos, ficando estes restritos mais às decisões do dia-a-dia. Os gestores, ao se envolverem com questões operacionais, permitem que elas tomem a maioria do seu tempo. Isso ocorre, em grande parte, porque eles conhecem bem todas as áreas e detêm um bom conhecimento técnico acerca dos processos envolvidos.

Embora haja centralização para a tomada de decisões importantes, a proximidade dos gestores com os funcionários parece ser benéfica, trazendo um sentimento de segurança e agilizando a solução dos problemas que 
surgem. Essa característica deve-se à estrutura simples, identificada nas três empresas, onde existe pouca formalização de processos e o fluxo de informações ocorre também informalmente.

Os gestores, embora demonstrem conhecer muito bem as oportunidades existentes no ambiente em que atuam, não praticam ações que possam levar a abertura de novos mercados, ficando restritos ao atendimento das demandas de seus clientes. Isso ocorre, na maioria das vezes, em função da grande urgência determinada por esses clientes para a conclusão dos projetos.

As ameaças ocorrem, principalmente, pelo rápido avanço tecnológico, que afeta diretamente as especificações de seus produtos e obrigam o aperfeiçoamento contínuo destes.

Foi observado que a maioria das ações estratégicas praticadas pelos gestores das empresas está sempre direcionada para a área comercial, ficando o desenvolvimento dos projetos com uma visão de curtíssimo prazo. Isso ocorre devido à ausência de controles mais precisos sobre os resultados da empresa, que a obriga a ficar numa posição mais de retaguarda.

Os gestores podem ser caracterizados como operadores, pois, suas atividades estão mais ligadas à seleção, ao desempenho dos projetos e à monitoração do trabalho.

Os pontos internos mais críticos concentram-se na obtenção de recursos para manutenção do seu funcionamento, porque o dinheiro obtido das fundações é canalizado exclusivamente para o desenvolvimento dos projetos, mas suas estruturas operacionais necessitam de capital de giro para sua continuidade e esse montante é, geralmente, financiado por terceiros.

\subsection{ESTILOS DE GESTÃO MAIS EVIDENTES NAS EMPRESAS}

Devido ao alto grau de conhecimento técnico, os funcionários têm grande liberdade para desenvolver seus próprios métodos de trabalho, demonstrando relativa maturidade para assumir responsabilidades e cumprir os prazos estipulados. Assim, a preocupação dos gestores é com a qualidade final do produto. Isso ocorre, principalmente, porque as empresas têm que atender às rígidas normas de controle de qualidade existentes em seus segmentos de 
atuação e que são pré-requisitos para a comercialização de seus produtos aqui no Brasil e em outros países.

A consciência, identificada nos gestores, em relação ao interesse dos funcionários pelas tarefas que executam, favorece o nível de liberdade atribuído a estes. Isso se torna importante considerando que desta forma, o gestor torna-se capaz de medir o resultado de suas ações, as quais estejam relacionadas à motivação dos seus funcionários.

A postura dos gestores em relação ao atingimento das metas apresentase como bastante flexível e, esse comportamento é justificado por eles como resultado da maturidade dos funcionários. Entretanto, ocorre mais pela ausência de tempo e de controles mais rígidos que possibilitem seu acompanhamento, do que pela presença de um estilo mais democrático, visto que é grande a pressão dos clientes para a conclusão dos projetos.

A grande proximidade entre os gestores e seus subordinados favorece 0 relacionamento entre eles, levando os gestores a um comprometimento com a solução dos problemas que atingem seus funcionários. O clima organizacional é de bastante interação e apresenta reflexos positivos no desempenho das empresas, facilitando, inclusive, o processo de identificação de pessoas com perfil de liderança, tal relação ocasiona uma liberdade de expressão que favorece a exposição de idéias por parte dos subordinados, possibilitando avaliar seu grau de comprometimento com a empresa. Essa característica foi observada nas três empresas pesquisadas.

\subsection{COMO O GESTOR CONTRIBUI PARA O PROCESSO DE INOVAÇÃO}

Embora, nas empresas pesquisadas, a inovação seja confiada à capacidade dos funcionários em exercê-la, sem processos sistemáticos de incentivo, a necessidade de manter competitivas as empresas competitivas faz com que seus gestores desenvolvam ações que podem ser descritas como de estímulo à inovação.

A preocupação com a qualidade, em atendimento às normas de controle, o clima de cooperação e a proximidade com o nível operacional faz emergir um ambiente de comprometimento com os resultados, levando seus 
funcionários à discussão sobre novos procedimentos relacionados com a melhoria dos processos e dos produtos.

A aproximação dos funcionários com os clientes, estimulada pelos gestores, faz crescer o sentimento de que estes são partes do processo, porém, afasta a possibilidade de ruptura de padrões. Essa idéia é reforçada pela declaração do entrevistado da empresa $A$, que declarou que o mercado não oferece espaço para testar produtos muito diferentes, por possuir padrões já estabelecidos. Esse fator é agravado pela política de contratação que, conforme já comentado, busca profissionais com perfil técnico definido. Sendo assim, eles têm dificuldades de enxergar além dos padrões aprendidos.

Não há uma periodicidade definida para a criação de novos processos e produtos, sendo seu ciclo desconhecido pelos gestores. As inovações aparecem, normalmente, quando há uma necessidade de revisão nos custos dos produtos, impulsionada pela pressão do mercado.

Desta forma, as empresas buscam mais as inovações incrementais do que radicais, sendo estimuladas principalmente pela manutenção de preços competitivos e não pela oferta de produtos que tragam diferencial tecnológico e valor agregado aos seus clientes.

A troca de informações entre os gestores e seus funcionários está limitada aos aspectos técnicos, ficando os assuntos estratégicos mais restritos à cúpula administrativa.

\subsection{DE QUE FORMA A EMPRESA BUSCA ALCANÇAR E/OU MANTER SUA POSTURA INOVADORA}

A ausência de um sistema de informações formal, que é descrito como uma das características das estruturas simples e orgânicas, faz com que as empresas não consigam reter conhecimentos que poderiam fazer emergir ações que as levassem à criação de inovações radicais.

O processo de criação é isolado, e fica retido nas pessoas ou na equipe que participa do desenvolvimento dos projetos. Apesar de esse perfil oferecer grande flexibilidade, em função da descentralização, estimulando inclusive o 
comportamento empreendedor, ele é arriscado por permitir que a base de conhecimentos fique retida somente com seus funcionários.

Desta forma, existe um ambiente onde se pode perceber a presença de um comportamento criativo e inovador, que é refletido na qualidade e confiabilidade atribuídas pelos clientes aos produtos produzidos pelas empresas pesquisadas, porém, não havendo um sistema mais elaborado para o registro dos processos desenvolvidos, as empresas acabam por criar uma crescente dependência das habilidades, da experiência e da motivação dos seus funcionários.

Sendo assim, com o envolvimento dos funcionários sendo estimulado pela manutenção do emprego e pela possibilidade de crescimento profissional, a dependência das empresas em relação ao conhecimento e experiência destes, cria uma enorme vínculo entre o atendimento às expectativas dos funcionários e a necessidade das empresas de inovar, o que pode ser altamente comprometedor para a garantia de manutenção e da sobrevivência das mesmas.

\subsection{CONTRIBUIÇÕES DA PESQUISA, SUAS LIMITAÇÕES E SUGESTÕES PARA TRABALHOS FUTUROS}

Esta pesquisa contribuiu para a identificação dos estilos de gestão presentes nas empresas pesquisadas, considerando que os resultados apresentados demonstram suas estruturas e descrevem o comportamento dos seus gestores, como também contribuiu para um melhor entendimento acerca das práticas presentes que possam ser identificadas com a inovação.

A característica orgânica das empresas, o comprometimento dos funcionários, o seu bom desempenho e a sua proximidade com os gestores, aliados a preocupação com o nível de qualidade dos produtos poderiam ser mais bem aproveitados no desenvolvimento de ações que levassem a um comportamento mais criativo nas empresas.

Para que isso ocorra, torna-se necessário que seus gestores desenvolvam aptidões voltadas para a criação de estratégias para a inovação, 
fazendo emergir novas perspectivas de negócios, desvinculadas de suas práticas cotidianas, tornando, assim, suas empresas mais competitivas.

As limitações da pesquisa estão relacionadas à impossibilidade de generalizações que o método de estudo de casos multicasos carrega em si. $O$ tamanho da amostra utilizada não permite considerar os resultados obtidos como característicos de toda pequena empresa, o que traria uma maior contribuição ao conhecimento acumulado sobre esse segmento empresarial.

Este trabalho também não teve como objetivo provocar uma relação de causa e efeito entre os estilos de gestão encontrados e a capacidade inovativa das empresas. Desta forma, outros estudos poderiam ser realizados com o objetivo de identificar um estilo de gestão que favoreça a capacidade inovadora das pequenas empresas, melhorando sua competitividade. 


\section{REFERÊNCIAS}

ANSOFF, I. (1990). A nova estratégia empresarial. São Paulo: Atlas.

BAPTISTA, R. F. (2000). Redes de inovação no contexto dos tecnopólos: a experiência de São Carlos, Brasil. Revista Electrónica de Geografía y Ciencias Sociales. Universidad de Barcelona [ISSN 1138-9788] № 69 (32). Disponível em: www.ub.es/geocrit/sn-69-32.htm. Acesso em: 09 set. 2004.

BATEMAN, T.S.; SNELL, S. A. (1998). Administração: construindo vantagem competitiva. São Paulo: Atlas.

BEAUD, M. (1999). História do capitalismo: de 1500 aos nossos dias. São Paulo: Brasiliense.

BERGAMINI, C. W. (1994). Liderança: administração do sentido. São Paulo: Atlas.

CASAROTTO FILHO, N. (2002). Projeto de negócio: estratégias e estudos de viabilidade: redes de empresas, engenharia simultânea, plano de negócio. São Paulo: Atlas.

; PIRES, L. H. (2002). Redes de pequenas e médias empresas e desenvolvimento local. São Paulo: Atlas.

CERTO, S. (2003). Administração Moderna. 9 ed. São Paulo: Prentice Hall.

CHRISTENSEN, C. M. (2002). The rules of innovation. Technology Review. Jun. p.33.

CLARK, K.; FUJIMOTO, T. (1991). Product development performance: strategy, organization and management in word auto industry. HBR. p.129-165.

DRUCKER, P. F. (1997) A nova era da administração. São Paulo: Pioneira Thomson. 
. (1999). Administrando em tempos de grandes mudanças. São Paulo: Pioneira; São Paulo: Publifolha.

FAPESP. (08/2005). Disponível em: <http://www.fapesp.com.br>. Acesso em: 05/08/2005)

FILION, L. J. (1999). Diferenças entre sistemas gerenciais de empreendedores e operadores de pequenos negócios. RAE - Revista de Administração de Empresas. Out/Dez. São Paulo, v.39, n.4, p.6-20.

FOWLER, F. (1998) Programas de desenvolvimento de empreendedores caso Durham/UK e FEA/USP/BRASIL. In: Anais do XX Simpósio de Gestão da Inovação Tecnológica. São Paulo. Anais...São Paulo: FEA/USP. p.527 - 539.

GIL, A. C. (2002). Como elaborar projetos de pesquisa. 4. ed. São Paulo: Atlas.

GRINNELL, J. P. (2003). An Empirical Investigation of CEO Leadership in Two Types of Small Firms. S.A.M. Advanced Management Journal, n.68, v.4, ABI/INFORM Global, p.36.

HAMEL, G.; SKARZYNSKI, P. (2001). Innovation: The new route to wealth. Journal of Accountancy. 192, v.5, ABI/INFORM Global, p.65.

HAMPTON, D. R. (1990). Administração: comportamento organizacional. São Paulo: McGrawl-Hill.

HERSEY, P.; BLANCHARD, K. (1974). Psicologia para Administradores de Empresas: a utilização de recursos humanos. São Paulo: EPU.

IBGE - Instituto Brasileiro de Geografia e Estatística. (2004). Download IBGE Disponível em: <http://www2.ibge.gov.br/pub/Micro_Empresa/2001/>. Acesso em: 26 mar. 2004.

LA ROVERE, R. L.; MEDEIROS, J. R. (2000). Gestão da inovação em pequenas e médias empresas: um estudo de caso. In: Anais do XXI Simpósio de Gestão da Inovação Tecnológica. São Paulo. Anais...São Paulo: FEA/USP. 
LEONARD-BARTON, D. (1998). Nascentes do saber: criando e sustentando as fontes de inovação. Rio de Janeiro: FGV.

LIKERT, R. (1979). Novos padrões de administração. 2.ed. São Paulo: Pioneira.

LODI, J. B. (2003). História da Administração. São Paulo: Pioneira Thomson Learning.

LONGENECKER, J. G.; MOORE, C. W.; PETTY, J. W. (1997). Administração de pequenas empresas. São Paulo: Makron Books.

MATTAR, F. N. (1988). Os motivos que levam as pequenas empresas à morte. Disponível em: <http://www.fauze.com.br/artigo33.htm>. Acesso em: 10 fev. 2004.

MAXIMIANO, A. C. A. (2002). (2004). Introdução à Administração. 6.ed. São Paulo: Atlas.

MERCOSUL. (2005). Disponível em: <http://www.mercosur.org.uy>. Acesso em: 05/08/2005.

MINTZBERG, H. (2003). Criando organizações eficazes: estruturas em cinco configurações. 2.ed. São Paulo: Atlas.

NAISBITT, J. (1999). Paradoxo global. Rio de Janeiro: Campus; São Paulo: Publifolha.

NONAKA, I. (1997). The knowledge-creating company. Harvard Business Review. Boston: Nov/Dec 1991. v.69, n.6; p.96.

PERUSSI FILHO, S. (2001). Uma avaliação da contribuição das cooperações universidade-empresa e inter-empresas para a competitividade das empresas industriais do pólo tecnológico de São Carlos. Dissertação (mestrado). Escola de Engenharia de São Carlos, Universidade de São Paulo.

PORTER, M. E. (1998). Estratégia - A Busca da Vantagem Competitiva. Rio de Janeiro: Editora Campus. 
. (1999). O que é estratégia. In: PORTER, M. E. Competição.

Estratégias competitivas essenciais. Rio de Janeiro: Editora Campus.

PZYSIEZNIG FILHO. J. (1998). O "venture capital” no desenvolvimento tecnológico. In: Anais do XX Simpósio de Gestão da Inovação Tecnológica. São Paulo. Anais...São Paulo: FEA/USP. p.961 - 972.

RESNIK, P. (1990). A Bíblia da Pequena Empresa: Como Iniciar com Segurança Sua Pequena Empresa e Ser Bem-Sucedido. São Paulo: Makron Books.

SABBAG, P. Y. (2000). A inovação e a gestão do conhecimento. In: Anais do XXI Simpósio de Gestão da Inovação Tecnológica. São Paulo. Anais...São Paulo: EAESP/FGV - Escola de Administração de São Paulo da Fundação Getulio Vargas.

SCHULER, R. S.; JACKSON, S. E. (1995). Linking competitive strategies with human resource management practices. IN: MINER, J.B.; CRANE, D. $P$. Advances in the practice, theory and research of strategic of human resource management. New York, Harper Collins College.

SEBRAE. (2002). Disponível em: <www.sebrae.com.br>. Acesso em: 15 fev. 2002.

$\overline{0} \overline{9}$ set. 2004 .

2004). Disponível em: <www.sebrae.com.br>. Acesso em:

SLACK, N. (1999). Administração da produção. ed. compacta. São Paulo: Atlas.

SUTTON, R. I. (2003). Weird ideas that spark innovation. Sloan Management Review. MIT, v.43, n.2. In: HSM Management . Jan/Feb. 2003, p.86-92.

TEDLOW. R. S. (2002). 7 Homens e os Impérios que Construíram. São Paulo: Futura.

TERENCE, A. C. F. (2002). Planejamento estratégico com ferramenta de competitividade na pequena empresa: desenvolvimento e avaliação de um 
roteiro prático para o processo de elaboração do planejamento. Dissertação (mestrado). Escola de Engenharia de São Carlos, Universidade de São Paulo.

UTTERBACK, J. (1996). Dominando a dinâmica da inovação. Quality Mark. p.25-181.

VERGARA, S. C. (2000). Projetos e relatórios de pesquisa em administração. São Paulo: Atlas.

WHEELWRIGHT, S.; CLARK, K. (1992). Revolutionizing Product Developement. The Free Press. p.29-187. 


\section{APÊNDICE A}

\section{CARACTERIZAÇÃO GERAL DA EMPRESA}

Nome da empresa:

Endereço:

Cidade/Estado:

Telefones:

Fax:

E-mail:

Home page:

Setor de atuação:

Ramo de atividade:

Data de fundação:

Área construída: $\mathrm{m}^{2}$

CNPJ e/ou IE:

$\mathrm{N}^{\circ}$ empregados:

Filiais:

Faturamento médio anual

Proprietários:

- nome:

- atividade principal:

- nome:

- atividade principal:

- nome:

- atividade principal: 


\section{PRODUTOS E SERVIÇOS OFERECIDOS}

Nome / tipo

Representatividade no faturamento (\%)

\begin{tabular}{|l|l|l|}
\hline \multicolumn{3}{|c|}{ Principais clientes } \\
\hline Nome & $\begin{array}{c}\text { Representatividade no } \\
\text { faturamento (\%) }\end{array}$ & $\begin{array}{c}\text { Cidade onde se } \\
\text { localiza }\end{array}$ \\
\hline & & \\
\hline & & \\
\hline & & \\
\hline & & \\
\hline
\end{tabular}

\begin{tabular}{|l|c|c|c|c|}
\hline \multicolumn{5}{|c|}{ Principais concorrentes } \\
\hline Ordem de importância para a empresa & $\begin{array}{c}\text { Cidade onde se } \\
\text { localiza }\end{array}$ & \multicolumn{3}{|c|}{$\begin{array}{c}\text { Participaça no mercado } \\
\text { (\%) }\end{array}$} \\
\cline { 3 - 5 } & & Local & $\begin{array}{c}\text { Regio- } \\
\text { nal }\end{array}$ & $\begin{array}{c}\text { Nacio- } \\
\text { nal }\end{array}$ \\
\hline $1^{\circ}$ & & & & \\
\hline $2^{\circ}$ & & & & \\
\hline $3^{\circ}$ & & & & \\
\hline $4^{\circ}$ & & & & \\
\hline $5^{\circ}$ & & & & \\
\hline
\end{tabular}




\begin{tabular}{|c|c|c|c|c|c|c|c|c|c|c|c|}
\hline \multirow{2}{*}{\begin{tabular}{|l|} 
Características dos concorrentes \\
Qualidade dos produtos \\
\end{tabular}} & \multicolumn{11}{|c|}{$\begin{array}{c}\text { Situação } \\
\text { (lembrando que quanto mais próximo de } 0 \text { o } \\
\text { ponto é mais fraco e quanto mais próximo de } 10 \\
\text { o ponto é mais forte) }\end{array}$} \\
\hline & 0 & 1 & 2 & 3 & 4 & 5 & 6 & 7 & 8 & 9 & 10 \\
\hline Linha de produtos diversificada & 0 & 1 & 2 & 3 & 4 & 5 & 6 & 7 & 8 & 9 & 10 \\
\hline Preço dos produtos & 0 & 1 & 2 & 3 & 4 & 5 & 6 & 7 & 8 & 9 & 10 \\
\hline Condições de pagamento facilitadas & 0 & 1 & 2 & 3 & 4 & 5 & 6 & 7 & 8 & 9 & 10 \\
\hline Relacionamento com os clientes & 0 & 1 & 2 & 3 & 4 & 5 & 6 & 7 & 8 & 9 & 10 \\
\hline $\begin{array}{l}\text { Rapidez na entrega dos produtos ao } \\
\text { cliente }\end{array}$ & 0 & 1 & 2 & 3 & 4 & 5 & 6 & 7 & 8 & 9 & 10 \\
\hline Imagem da empresa no mercado & 0 & 1 & 2 & 3 & 4 & 5 & 6 & 7 & 8 & 9 & 10 \\
\hline $\begin{array}{l}\text { Capacidade inovação (criação de } \\
\text { novos produtos) }\end{array}$ & 0 & 1 & 2 & 3 & 4 & 5 & 6 & 7 & 8 & 9 & 10 \\
\hline Participação no mercado local & 0 & 1 & 2 & 3 & 4 & 5 & 6 & 7 & 8 & 9 & 10 \\
\hline Participação no mercado regional & 0 & 1 & 2 & 3 & 4 & 5 & 6 & 7 & 8 & 9 & 10 \\
\hline Participação no mercado nacional & 0 & 1 & 2 & 3 & 4 & 5 & 6 & 7 & 8 & 9 & 10 \\
\hline Capacidade de exportação & 0 & 1 & 2 & 3 & 4 & 5 & 6 & 7 & 8 & 9 & 10 \\
\hline
\end{tabular}

\begin{tabular}{|l|c|}
\hline \multicolumn{2}{|c|}{ Principais fornecedores } \\
\hline \multicolumn{1}{|c|}{ Ordem de importância para a empresa } & $\begin{array}{c}\text { Cidade onde se } \\
\text { localiza }\end{array}$ \\
\hline $1^{\circ}$ & \\
\hline $2^{\circ}$ & \\
\hline $3^{\circ}$ & \\
\hline $4^{\circ}$ & \\
\hline $5^{\circ}$ & \\
\hline
\end{tabular}




\begin{tabular}{|l|c|c|c|c|c|c|c|c|c|c|c|}
\hline Características dos fornecedores & \multicolumn{8}{|c|}{ Situação } \\
& \multicolumn{8}{|c|}{$\begin{array}{c}\text { (lembrando que quanto mais próximo de } 0 \text { o } \\
\text { oonto é mais fraco e quanto mais próximo de }\end{array}$} \\
& \multicolumn{7}{|c|}{10 onto é mais forte) } \\
\hline Qualidade da matéria-prima & $\mathbf{0}$ & $\mathbf{1}$ & $\mathbf{2}$ & $\mathbf{3}$ & $\mathbf{4}$ & $\mathbf{5}$ & $\mathbf{6}$ & $\mathbf{7}$ & $\mathbf{8}$ & $\mathbf{9}$ & $\mathbf{1 0}$ \\
\hline Preço da matéria-prima & $\mathbf{0}$ & $\mathbf{1}$ & $\mathbf{2}$ & $\mathbf{3}$ & $\mathbf{4}$ & $\mathbf{5}$ & $\mathbf{6}$ & $\mathbf{7}$ & $\mathbf{8}$ & $\mathbf{9}$ & $\mathbf{1 0}$ \\
\hline Tecnologia de fabricação & $\mathbf{0}$ & $\mathbf{1}$ & $\mathbf{2}$ & $\mathbf{3}$ & $\mathbf{4}$ & $\mathbf{5}$ & $\mathbf{6}$ & $\mathbf{7}$ & $\mathbf{8}$ & $\mathbf{9}$ & $\mathbf{1 0}$ \\
\hline Relacionamento de cooperação & $\mathbf{0}$ & $\mathbf{1}$ & $\mathbf{2}$ & $\mathbf{3}$ & $\mathbf{4}$ & $\mathbf{5}$ & $\mathbf{6}$ & $\mathbf{7}$ & $\mathbf{8}$ & $\mathbf{9}$ & $\mathbf{1 0}$ \\
\hline Troca de informações técnicas & $\mathbf{0}$ & $\mathbf{1}$ & $\mathbf{2}$ & $\mathbf{3}$ & $\mathbf{4}$ & $\mathbf{5}$ & $\mathbf{6}$ & $\mathbf{7}$ & $\mathbf{8}$ & $\mathbf{9}$ & $\mathbf{1 0}$ \\
\hline
\end{tabular}




\section{APÊNDICE B}

\section{QUESTÕES ESPECÍFICAS}

\section{Questões relativas à empresa:}

1.1 Qual o percentual aproximado dos custos administrativos em relação aos custos totais?

1.2 Existem gestões distintas entre as áreas: comercial, administrativa e de produção. De que maneira elas estão organizadas?

1.3 Como é formado o organograma da empresa?

1.4 Que tipo de decisão deve ser tomada exclusivamente pela Diretoria da empresa e quais decisões são resolvidas pela média administração? 
1.5 Como são avaliados os riscos associados às decisões tomadas pela empresa?

1.6 Como é organizado o fluxo de informações dentro da empresa?

1.7 Quanto tempo, em média, uma decisão importante leva para ser aprovada?

1.8 Decisões importantes devem passar obrigatoriamente por quais procedimentos antes que sejam avaliadas? 
1.9 Quantas pessoas participam das decisões consideradas importantes para o futuro da empresa? De que forma se dá essa participação?

1.10 De que maneira são resolvidos os conflitos internos na empresa?

1.11 Até que ponto os subordinados considerados especialistas nas suas tarefas têm poder para tomada de decisões?

1.12 Qual a composição das equipes de trabalho que são formadas em torno dos diversos projetos que surgem na empresa? 
1.13 Quais atividades você apontaria como as que mais ocupam o tempo dos diretores? Ex.: monitoramento das atividades cotidianas da empresa, expansão de mercado e criação de novos produtos, motivação da força de trabalho, marketing, planejamento e outras. E dos supervisores e gerentes?

1.14 Cite os pontos fortes e fracos da empresa.

1.15 Comente sobre as oportunidades e ameaças existentes no ambiente onde a empresa atua.

1.16 Explique de que maneira são traçadas as metas da empresa. 
1.17 Qual é o procedimento utilizado para documentar as decisões estratégicas adotadas pela Diretoria?

1.18 Defina o negócio da empresa. Existe uma declaração da missão? Descreva.

1.19 Qual o envolvimento da alta cúpula na busca de informações que levem à obtenção de vantagens competitivas? Como isso é feito na prática?

1.20 Com a empresa é capaz de atender clientes que pertençam a nichos específicos de mercado? Essa atuação já existe na empresa? 
1.21 Como você avalia o ambiente onde a empresa atua?

1.22 Qual o grau de certeza que esse ambiente propicia para a empresa, na hora da tomada de decisões?

1.23 Quais ações ou acontecimentos externos mais afetam a empresa?

1.24 Como a empresa avalia a concorrência? Existe cooperação ou troca de experiências? 
1.25 Qual o diferencial da empresa em relação aos seus principais concorrentes?

1.26 Avalie a relação comercial da empresa com seus maiores clientes e seus maiores fornecedores.

2 Questões relativas ao estilo de gestão:

2.1 Em geral, qual o grau de independência com o qual os funcionários conduzem suas atividades do dia-a-dia?

2.2 Quais regras da empresa devem ser observadas com mais atenção na hora de execução do trabalho? 
2.3 Até que grau a adaptação dessas regras a outras maneiras de se executar o trabalho poderá ser tolerado?

2.4 Em sua opinião, como é possível perceber o interesse do funcionário pela tarefa que executa? Com qual freqüência isso ocorre na empresa?

2.5 Como está definido o plano de cargos e salários na empresa?

2.6 Quais atitudes, por parte dos gestores da empresa, você acredita que possam estar mais relacionadas com a aceitação das individualidades e necessidades dos subordinados? 
2.7 Na empresa, como os gestores avaliam a necessidade de alcance das metas por partes dos seus subordinados? Até que ponto as individualidades são consideradas nesse contexto?

2.8 Com qual freqüência os gestores mantêm contato com seus subordinados para resolver questões pessoais?

2.9 Como é feita a verificação do grau de comprometimento dos gestores em relação às metas estabelecidas?

2.10 De que maneira você acredita que seus funcionários possam aprendem com os próprios erros? 
2.11 Qual o perfil desejável de um funcionário que ocupa cargo de supervisão ou gerência?

2.12 Como você avalia os seus atuais supervisores e gerentes?

2.13 De que forma se dá a divulgação das metas pelos gestores aos seus subordinados? Quais ações são combinadas entre eles para atingir essas metas?

2.14 Quais ações, por parte dos gestores, tornam-se mais eficientes na motivação dos funcionários para o atingimento das metas? 
2.15 Quais os requisitos para que um funcionário possa ser promovido dentro da empresa?

2.16 Qual a participação dos supervisores ou gerentes no processo de promoção interna de seus subordinados?

2.17 Quais são as maneiras possíveis dentro da empresa para que os funcionários possam ser recompensados, de forma não monetária, pelo seu chefe, quando apresentam bom desempenho no trabalho?

2.18 Descreva o tipo de equipe de trabalho existente na empresa que é mais valorizada pelos funcionários. 
2.19 Qual a forma encontrada para motivar seus funcionários a desenvolver idéias e ações inovadoras dentro da empresa?

2.20 Quanto tempo, em média, um funcionário não ligado a P\&D pode se dedicar a desenvolver idéias que possam melhorar os processos ou os produtos da empresa?

2.21 Quais parâmetros são utilizados inicialmente para avaliar idéias e sugestões de novos processos ou produtos?

2.22 Como os gestores conseguem criar situações que estimulem idéias e sugestões? 
2.23 De que maneira e com qual freqüência surgem novas idéias que visam à melhoria de produtos ou processos internos?

2.24 Como a empresa oferece condições para que funcionários não ligados à P\&D opinem sobre produtos e processos internos?

2.25 Cite exemplos de idéias que, embora inicialmente parecessem estranhas, foram desenvolvidas e executadas pela empresa, com sucesso ou não.

2.26 Qual a sua opinião em relação à contratação de pessoas que tenham uma cultura muito diferente da empresa? Existem funcionários que se enquadrem nessa condição? 
2.27 Como são organizadas as equipes de trabalho? De que forma seus membros são escolhidos?

2.28 Como se dá o intercâmbio entre administradores e funcionários acerca de assuntos estratégicos?

2.29 De que maneira a empresa busca, internamente, novas visões de negócios?

2.30 Você acredita que todos os funcionários sentem-se parte do processo estratégico da empresa? Por quê? 
2.31 Qual é o percentual de informações estratégicas que são repassadas a toda a organização? Por que, se for o caso, alguns dados são considerados sigilosos?

\section{Questões relativas à inovação:}

3.1 Descreva como os novos funcionários são treinados para o trabalho na empresa.

3.2 Quais oportunidades são criadas para que os funcionários mais antigos compartilhem informações com os funcionários menos experientes?

3.3 Quais requisitos são mais bem avaliados quando da contratação de funcionários? 
3.4 Explique, de maneira sucinta, como são conduzidos os programas de treinamento na empresa.

3.5 De que maneira são atendidas as solicitações dos funcionários para participação em cursos de aperfeiçoamento profissional?

3.6 A empresa possui algum banco de sugestões? Caso possua um, ou algo semelhante, como ele funciona?

3.7 Qual o sistema de recompensas que a empresa adota para premiar os funcionários que trazem contribuições criativas para os processos internos da empresa? 
3.8 Descreva como são os programas internos desenvolvidos exclusivamente com a finalidade de integração social dos funcionários. Existe algum departamento de eventos esportivos, sociais ou outros?

3.9 Descreva como são as atividades ligadas diretamente ao desenvolvimento de novos produtos ou processos.

3.10 Qual o padrão a ser seguido na hora de modificar métodos e procedimentos de trabalho?

3.11 Informe, aproximadamente, quanto é gasto por ano com pesquisa e desenvolvimento de novos produtos. 
3.12 De acordo com suas observações, em relação aos funcionários, quais atividades tornam-se mais eficientes para o aprendizado individual?

3.13 Em uma visão mais geral, qual o perfil do funcionário que apresenta características empreendedoras?

3.14 Como são realizados os trabalhos em equipe?

3.15 Como se dá a participação da empresa em programas de estímulo à inovação? 
3.16 Como se dá a participação dos gestores em feiras e congressos?

3.17 Como são os vínculos da empresa com empresas maiores?

3.18 Como são organizados os manuais e as normas internas da empresa? De que forma é possível a consulta ao material descrito?

3.19 Como são separadas as normas técnicas das normas administrativas? Qual o meio eletrônico no qual ambas estão disponíveis? 
3.20 Qual é a filosofia empresarial mais evidente e quais comportamentos são esperados de todos os membros para que se atenham a essa filosofia?

3.21 O conhecimento tácito é tido como aquele que é de difícil descrição, mas que no entanto fica retido no cérebro dos funcionários mais habilidosos e não podem ser encontrados nos manuais da empresa. Como o gestor avalia essa questão, no âmbito estratégico da empresa?

3.22 Qual a forma encontrada pela empresa para que essa informação seja compartilhada com os outros membros da empresa?

3.23 Descreva quais melhorias geralmente atraem mais os clientes. Ex.: aquelas que trazem redução de custos, as que permitem mais precisão ou rapidez ao trabalho, etc 
3.24 Com qual freqüência os processos são revisados na empresa?

3.25 A empresa apresenta maior ênfase na melhoria de produtos ou de processos? Por quê?

3.26 Quais produtos são feitos exclusivamente sob encomenda, com características diferenciadas para o cliente?

3.27 Em sua opinião, o que torna a empresa mais competitiva no mercado?

3.28 Quem mais estimula a empresa a inovar: seus clientes ou seus fornecedores? Por quê? 
3.29 Como os gestores avaliam o processo de inovação? Eles o consideram como fator importante? Por quê? 